\title{
Phosphasalen group IV metal complexes: Synthesis, Characterisation and Ring Opening Polymerization of Lactide
}

\begin{abstract}
Adrien T. Normand, ${ }^{a}$ Raluca Malacea-Kabbara, ${ }^{a}$ Rosita Lapenta, ${ }^{c}$ Aymeric Dajnak, ${ }^{a}$ Philippe Richard, ${ }^{a}$ Hélène Cattey, ${ }^{a}$ Anaëlle Bolley, ${ }^{c}$ Alfonso Grassi, ${ }^{d}$ Stefano Milione, ${ }^{d}$ Audrey Auffrant, ${ }^{* b}$ Samuel Dagorne $^{* c}$ and Pierre Le Gendre*a

We report the synthesis of a series of $\mathrm{Zr}$ and $\mathrm{Ti}$ complexes bearing phosphasalen which differs from salen by the incorporation of two $\mathrm{P}$ atoms in the ligand backbone. The reaction of phosphasalen proligands (1a-1c) $\mathbf{H}_{2}$ with $\mathrm{Zr}\left(\mathrm{CH}_{2} \mathrm{Ph}\right)_{4}$ led to different products depending on the nature of the $\mathrm{N}, \mathrm{N}$-linker in the ligand. In case of ethylene-linked phosphasalen, octahedral $\mathrm{Zr}$ complex 2a formed as a single stereoisomer in trans geometry. With the phenylene linker, it was shown by dynamic NMR spectroscopy that complex $\mathbf{2} \mathbf{b}$ exists as a mixture of trans and cis- $\beta$ isomers in solution, both enantiomers ( $\Delta$ and $\Lambda$ ) of the cis- $\beta$ isomer being in fast equilibrium with respect to the NMR time-scale. The use of a propylene-linked phosphasalen proligand $\mathbf{1} \mathbf{C H}_{\mathbf{2}}$ led to a mixture of complexes among which a binuclear $\mathrm{Zr}$ complex $\mathbf{2} \mathbf{c}$ bridged only by one phosphasalen ligand could be isolated and characterized. Addition of 2 equiv of ${ }^{i} \mathrm{PrOH}$ to $\mathbf{2 a}$ and $\mathbf{2} \mathbf{b}$ afforded diisoproxy $\mathrm{Zr}$ complexes $\mathbf{3 a}$ and $\mathbf{3} \mathbf{b}$ as a mixture of trans and cis- $\beta$ isomers, the latter undergoing fast $\Delta / \Lambda$ isomerization in solution. Addition of $B\left(C_{6} F_{5}\right)_{3}$ to $\mathbf{2 a}$ and $\mathbf{2} \mathbf{b}$ gave cationic monobenzyl $\mathrm{Zr}$ complexes $\mathbf{4 a}$ and $\mathbf{4} \mathbf{b}$ which have been further converted into cationic alkoxy $\mathrm{Zr}$ complexes $\mathbf{5} \mathbf{a}-\mathbf{b}$ and $\mathbf{6 a - b}$ by alcoholysis with ${ }^{i} \mathrm{PrOH}$ and $(S)$-methyl-lactate, respectively. The reaction of the phosphasalen proligands with $\mathrm{Ti}\left(\mathrm{NMe}_{2}\right)_{4}$ proceeded diastereoselectively giving rise to $\mathrm{Ti}$ complexes $\mathbf{7 a}-\mathrm{c}$ in octahedral geometry with cis- $\beta$ wrapping of the ligand. The complexes have been tested for the ROP of rac-lactide. The neutral phosphasalen $\mathrm{Ti}$ and $\mathrm{Zr}$ complexes showed only poor activity probably due to the encumbered and electron donating nature of the phosphasalen ligand. In contrast, the cationic $\mathrm{Zr}$ alkoxides $\mathbf{5 a} \mathbf{6} \mathbf{6} \mathbf{a}$ and $\mathbf{6 b}$ are effective initiators for the controlled and hetero-selective ROP of rac-lactide.
\end{abstract}

\section{Introduction}

Poly(lactic acid) (PLA) is considered today as the most promising biosourced and biodegradable alternative to petrochemically based plastics. ${ }^{1}$ Depending on its microstructure, PLA features highly different mechanical and thermal properties and can find applications ranging from soft materials to engineering plastic materials. ${ }^{2}$ The Ring Opening Polymerization (ROP) of lactide constitutes the most attractive route to produce such polymers in a controlled manner. Intensive research has been carried out in this field and highly active initiators able to give high molecular weight PLA polymers with low polydispersity and controlled tacticity have been described. ${ }^{3}$ Group 4 complexes have shown great potential as ROP initiators and some

a. Institut de Chimie Moléculaire de l'Université de Bourgogne (ICMUB), Université de Bourgogne Franche-Comté (UMR-CNRS 6302), 9, av. A. Savary, 21078 Dijon, France.

b. Laboratoire de Chimie Moléculaire, CNRS UMR 9168, École Polytechnique, Institut Polytechnique de Paris, 91128 Palaiseau, France.

c. Institut de Chimie de Strasbourg (UMR-CNRS 7177), Université de Strasbourg.

d. Dipartimento di Chimica e Biologia, Universita degli Studi di Salerno, via Giovanni Paolo II, 132-84084 Fisciano (SA), Italy

Electronic Supplementary Information (ESI) available: CIF files for compounds $\mathbf{1 a H}_{2}$

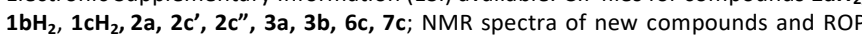
studies. combinations with salen (I), salan (II) and salalen (III) ligands have been found to be particularly efficient (Figure 1). ${ }^{4}$ For example, dialkoxy titanium complexes with salen ligands lead to atactic PLA with narrow PDIs and high molecular weights. ${ }^{5}$ Switching to more flexible salan and salalen ligand leads to chelate zirconium and hafnium complexes able to produce high molecular weight heterotactically or isotactically enriched PLA from rac-lactide. ${ }^{6}$ In 2011, one of us described for the first time phosphasalen ligands (IV), a variant of salen which consists in a bis(iminophosphorane) moiety flanked by two phenoxy groups. ${ }^{7}$ Phosphasalen ligands resemble salen but their wrapping pattern and electron donating ability differ notably. In the former, the tetrahedral phosphorus atoms impart both increased flexibility and steric bulk to the ligand. Additionally,
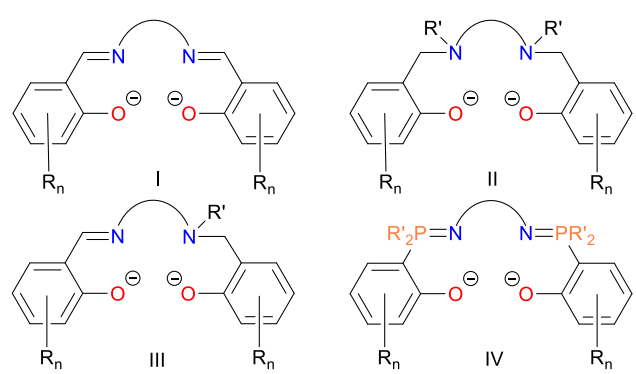
Figure 1 Salen (I), salan (II), salalen (III) and phosphasalen (IV) ligands

the stronger basicity of iminophosphoranes compared to imines, along with their lack of $\pi$-accepting properties, make phosphasalen better net donors than salen. These ligands, associated with rare earth metals (Sc, Y, La, Lu), were shown to be powerful initiators for the polymerization of rac-lactide with excellent rates and high stereoselectivities. ${ }^{8}$ In light of these results, we set out to combine phosphasalen ligands with group IV metal complexes to develop new lactide ROP catalysts. To the best of our knowledge, such combination has yet to be reported. Herein, we describe the synthesis and characterisation of a series of phosphasalen $\mathrm{Ti}$ and $\mathrm{Zr}$ complexes along with a preliminary assessment of their performance as lactide ROP iniators.

\section{Results and discussion}

\section{Synthesis and characterization of the phosphasalen proligands}

Phosphasalen proligands $(\mathbf{1} \mathbf{a}-\mathbf{1} \mathbf{c}) \mathbf{H}_{\mathbf{2}}$ were synthesized by adapting a previously reported procedure based on the Kirsanov reaction between 4,6-di(tert-butyl)-2(diphenylphosphino)phenol with bromine and the appropriate diamine, using either tributylamine or $\mathrm{DABCO}$ as $\mathrm{HBr}$ trapping agent (Scheme 1). ${ }^{8 b, 8 \mathrm{c}}$ Further deprotonation with two equivalents of potassium bis(trimethylsilyl)amide led to the proligands $(\mathbf{1} \mathbf{a}-\mathbf{1} \mathbf{c}) \mathrm{H}_{\mathbf{2}}$ in $41-55 \%$ yields. The range of diamines were chosen to study the impact of the bridging unit on the structure of the resultant metal complex and on the polymerization performances. Ortho-tert-butyl-substituted ligands were selected for their propensity to form discrete mononuclear species. The phosphasalen proligands $(\mathbf{1 a}-\mathbf{1 c}) \mathbf{H}_{\mathbf{2}}$

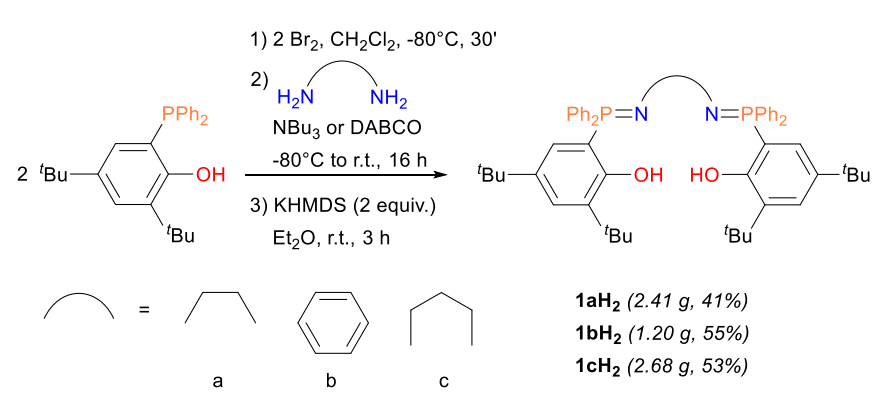

Scheme 1 Synthesis of phosphasalen proligands (1a-1c) $\mathbf{H}_{2}$ were characterized by ${ }^{31} \mathrm{P}\left\{{ }^{1} \mathrm{H}\right\},{ }^{1} \mathrm{H},{ }^{13} \mathrm{C} N \mathrm{NMR}, \mathrm{EA}$ and X-Ray diffraction analysis. In the solid state, $\mathbf{1 b H}_{\mathbf{2}}$ shows intramolecular hydrogen bonding between iminophosphorane moieties and nearby hydroxyl groups (Figure 2). Both phenol rings are tilted by $43^{\circ}$ and $71^{\circ}$ with respect to the mean plane defined by the four atoms N1, C1, C2 and N2 with the phenol oxygens $\mathrm{O} 1$ and $\mathrm{O} 2$ dipping below this plane. $\mathrm{P}-\mathrm{N}$ bond lengths in $\mathbf{1} \mathbf{b H}_{\mathbf{2}}$ are $1.579(2) \AA$ and $1.586(2) \AA$ in the range of those reported for iminophosphoranes. ${ }^{7 \mathrm{~b}, 9}$ Proligands $\mathbf{1} \mathbf{a H}_{\mathbf{2}}$ and $\mathbf{1} \mathbf{c H}_{\mathbf{2}}$ feature different dipolar form and spatial arrangement compared to $\mathbf{1} \mathbf{b H}_{\mathbf{2}}$. Both phenolic protons are transferred to iminophophoranes resulting in zwitterionic forms. This is consistent with the more basic character of the iminophosphorane functions in $\mathbf{1} \mathbf{a} \mathbf{H}_{\mathbf{2}}$ and $\mathbf{1} \mathbf{C H}_{\mathbf{2}}$ due to the alkylene spacer. Intramolecular electrostatic and hydrogen bonding interactions between the two opposite phenoxyaminophosphonium in a complementary pairing constrain the ligands to adopt a helical twist in a $C_{2}$-symmetric fashion ${ }^{\S}$. As expected, $\mathrm{P}-\mathrm{N}$ bond lengths in $\mathbf{1} \mathbf{a H}_{\mathbf{2}}$ and $\mathbf{1} \mathbf{c H}_{\mathbf{2}}$ are longer than that in $\mathbf{1} \mathbf{b H}_{\mathbf{2}}$ due to protonation (1.637(2) $\AA$ for $\mathbf{1} \mathbf{a H}_{\mathbf{2}}$ and $1.624(2), 1.623(2) \AA$ for $\left.1 \mathbf{c H}_{2}\right) .{ }^{10}$ The ${ }^{31} \mathrm{P}\left\{{ }^{1} \mathrm{H}\right\}$ NMR spectrum of $\mathbf{1 b H}_{\mathbf{2}}$ shows a signal at $18.1 \mathrm{ppm}$ in the range observed for other iminophosphoranes, ${ }^{7 a}$ while $\mathbf{1} \mathbf{a H}_{\mathbf{2}}$ and $\mathbf{1} \mathbf{c H}_{\mathbf{2}}$ give downfield shifted signals at $\delta=42.7$ and $39.4 \mathrm{ppm}$, respectively.

\section{Synthesis and characterization of the phosphasalen $\mathrm{Zr}$ complexes}

Based on previous studies of group IV metal complexes with salan/salalen ligands, we first targeted $\mathrm{Zr}$ complexes that generally lead to more active ROP initiators. If phosphasalen behaves as tetradentate ligand, three modes of coordination around the octahedral metal centre can be expected: trans, cis- $\alpha$ or cis- $\beta$ (Figure 3 ). In the last two cases, complexes are chiral and can exist as two enantiomers ( $\Delta$ and $\Lambda$ ).

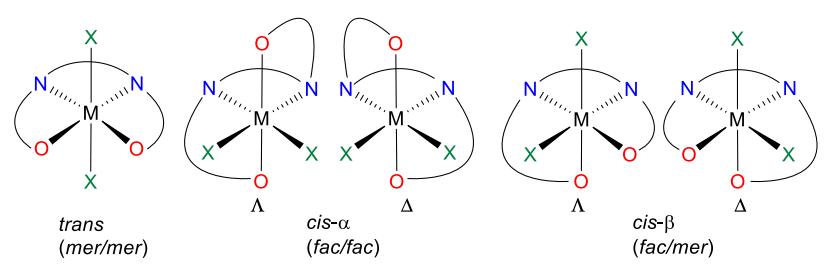

Figure 3 Possible coordination modes of tetradentate $\mathrm{O}, \mathrm{N}, \mathrm{N}, \mathrm{O}$ ligands around an octahedral metal centre

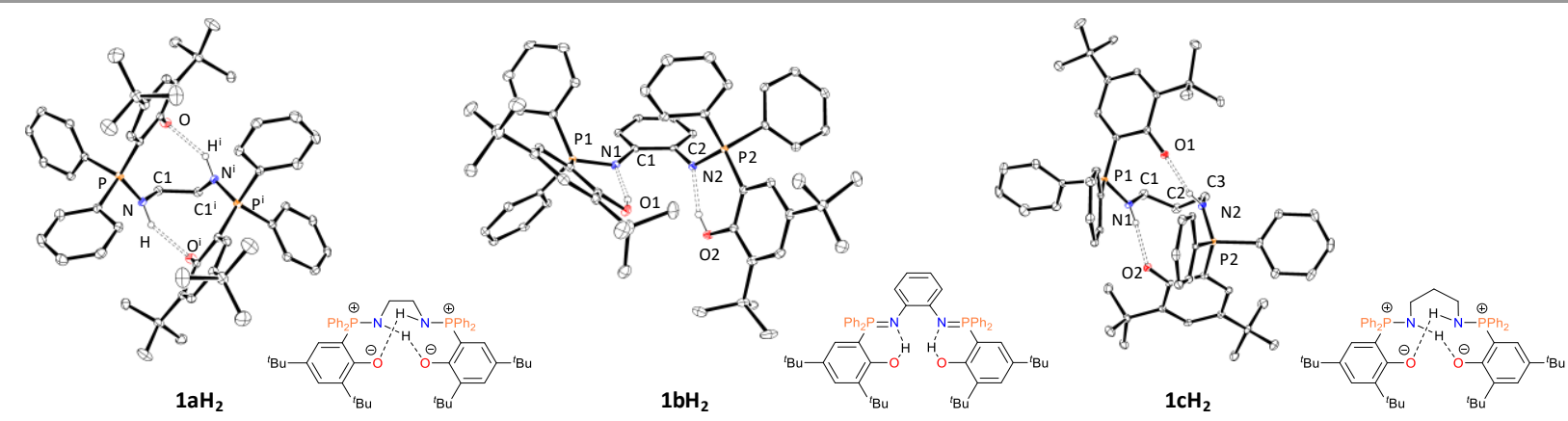

Figure 2 ORTEP view of phosphasalen proligands (1a-1c) $\mathbf{H}_{2}$. For the sake of clarity, $\mathrm{H}$ atoms (except for relevant ones) as well as disorder and solvent molecules (if any) are not shown. ${ }^{i}: 1-\mathrm{X},+\mathrm{Y}, 3 / 2-\mathrm{Z}$. 
The reaction of the proligands $(\mathbf{1 a}-\mathbf{1} \mathbf{c}) \mathrm{H}_{2}$ with $\mathrm{Zr}\left(\mathrm{CH}_{2} \mathrm{Ph}\right)_{4}$ led to different outcomes (Schemes 2-4). The ${ }^{31} \mathrm{P}\left\{{ }^{1} \mathrm{H}\right\}$ NMR spectrum of complex $2 \mathrm{a}$ in $\mathrm{C}_{6} \mathrm{D}_{6}$ at $298 \mathrm{~K}$ shows a singlet at $\delta=36.5 \mathrm{ppm}$ upfield shifted with respect to the signal of 1a. The presence of only two singlets for the ${ }^{t} \mathrm{Bu}$ groups, one singlet for the two residual benzylic groups and one multiplet for the ethylene spacer in the ${ }^{1} \mathrm{H}$ NMR spectrum of $2 \mathrm{a}$ suggests a $C_{2 v}$-symmetric trans complex in solution. X-ray diffraction analysis conducted on a single crystal of $\mathbf{2 a}$ corroborated this hypothesis. The $\mathrm{Zr}$ atom is located on a true crystallographic $C_{2}$-symmetry axis and, as shown in Figure 4, exhibits a pseudo-octahedral coordination scheme. Comparison with ( $\left.{ }^{t} \mathrm{BuSalfen}\right) \mathrm{Zr}\left(\mathrm{CH}_{2} \mathrm{Ph}\right)_{2}$ reported by Arnold in the same trans geometry shows shorter $\mathrm{Zr}-\mathrm{N}$ bond distances (by ca $0.15 \AA$ ) and longer $\mathrm{Zr}$-C distances (by ca $0.03 \AA$ ) in the phosphasalen complex. ${ }^{11} \mathrm{P}-\mathrm{N}$ bonds lengths are slightly shortened (by ca $0.018(3) \AA$ ) compared to those in $\mathbf{1 a H}_{\mathbf{2}}$.

The reaction of the proligand $\mathbf{1 b H}_{\mathbf{2}}$ with $\mathrm{Zr}\left(\mathrm{CH}_{2} \mathrm{Ph}\right)_{4}$ gave complex $\mathbf{2} \mathbf{b}$ as a mixture of trans and cis- $\beta$ isomers which was characterized by VT and low temperature NMR experiments (Scheme 3). At $200 \mathrm{~K}$, the ${ }^{31} \mathrm{P}\left\{{ }^{1} \mathrm{H}\right\}$ NMR spectrum of $\mathbf{2 b}$ recorded at $243 \mathrm{MHz}$ in $\mathrm{d}_{8}$-THF shows one peak at $\delta=29.5 \mathrm{ppm}$, which can be tentatively assigned to the trans isomer and a set of two peaks at $\delta=28.3$ and $30.8 \mathrm{ppm}$ consistent with a $C_{1}$-symmetric cis- $\beta$ complex (Figure 5). Upon heating up to $330 \mathrm{~K}$, the ${ }^{31} \mathrm{P}$ signal of the trans isomer does not change significantly whereas those of cis- $\beta$ isomer broaden slowly, collapse at $300 \mathrm{~K}$ and then decoalesce to give one broad peak centred at $\delta=28.3 \mathrm{ppm}$ $\left(\Delta \mathrm{v}_{1 / 2}=131.9 \mathrm{~Hz}\right)$.

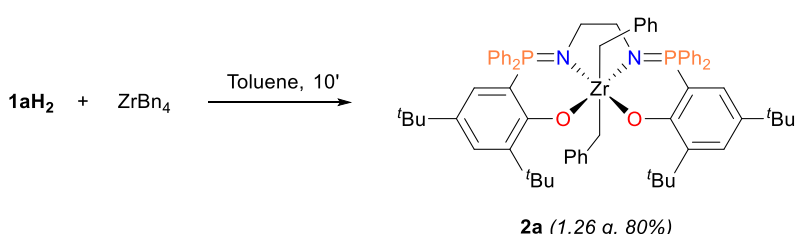

2a $(1.26 \mathrm{~g}, 80 \%)$

Scheme 2

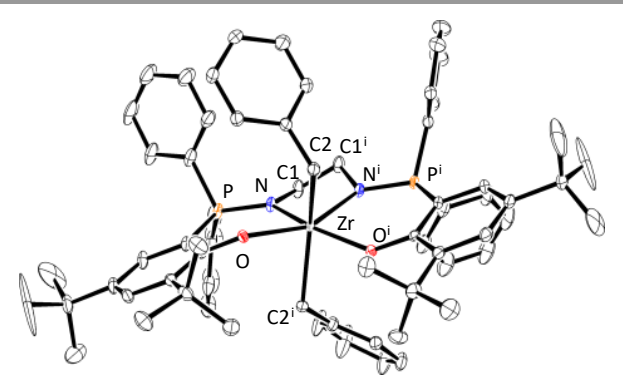

Figure 4 ORTEP view of complex 2a (hydrogen atoms are omitted for clarity). Selected distances $(\AA ̊)$ and angles (deg): C2-Zr 2.350(2), N-P 1.6194(18), N-Zr 2.2033(17), O-Zr 2.0582(14), C2i-Zr-C2 143.92(12), Ni-Zr-N 74.74(9), O-Zr-O' 122.96(8). ${ }^{i} 1-X,+Y, 3 / 2-Z$.

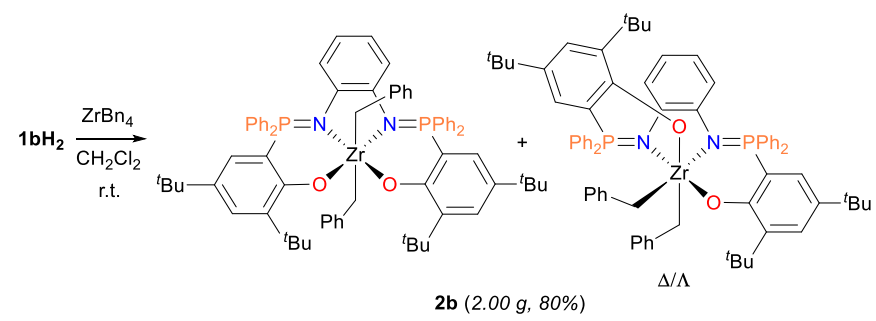

Scheme 3 (only one cis- $\beta$ enantiomer shown for clarity)

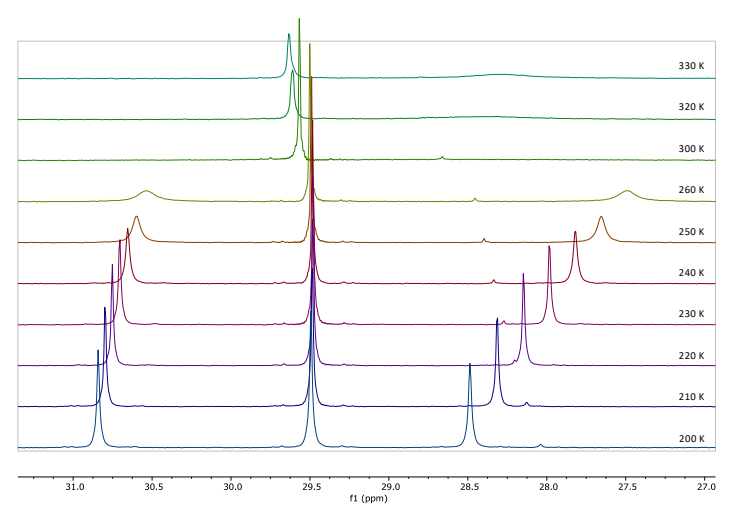

Figure 5 Variable-temperature ${ }^{31} \mathrm{P}\left\{{ }^{1} \mathrm{H}\right\} \mathrm{NMR}$ spectra of $\mathbf{2 b}\left(243 \mathrm{MHz}, \mathrm{d}_{8}\right.$-THF)

Heating the sample also induces the partial isomerization of trans-2b to cis- $\beta-\mathbf{2} \mathbf{b}$ (ratio trans:cis- $\beta=1: 1.4$ at $200 \mathrm{~K}$ and 1:2.4 at $330 \mathrm{~K}$ ). In the ${ }^{1} \mathrm{H}$ NMR spectra of complex $\mathbf{2} \mathbf{b}$ recorded from $200 \mathrm{~K}$ up to $330 \mathrm{~K}$, the benzyl methylenic protons of the trans isomer appear as one singlet at chemical shifts ranging from 1.74 to $1.83 \mathrm{ppm}$ consistent with a $C_{2 \mathrm{v}}$-symmetric complex. The same protons in the cis- $\beta$ isomer produce four multiplets centred at $\delta=1.67,1.79,2.09$ and $2.37 \mathrm{ppm}$ at $210 \mathrm{~K}$ and one broad singlet centred at $\delta=2.06 \mathrm{ppm}$ at $300 \mathrm{~K}$. The dynamic NMR behaviour of the cis- $\beta$ isomer of $\mathbf{2} \mathbf{b}$ can be explained by an isomerization between $\Delta$ and $\Lambda$ enantiomers. In order to get accurate thermodynamic constants, analogous VT NMR experiments were conducted in $\mathrm{d}_{8}$-toluene solution of $\mathbf{2 b}$ within a broader temperature range ( $200 \mathrm{~K}$ to $350 \mathrm{~K}$ ). An Eyring plot of $\ln (\mathrm{k} / \mathrm{T})$ against $1 / \mathrm{T}$ gives an enthalpy of activation $\Delta \mathrm{H}^{\ddagger}=45.9$ $( \pm 4.3) \mathrm{kJ} \cdot \mathrm{mol}^{-1}$ and an entropy of activation $\Delta \mathrm{S}^{\ddagger}=-34( \pm 16)$ J.mol ${ }^{-1}, \S$ comparable to other cis- $\beta \mathrm{Zr}$ complexes which undergo the same inversion of configuration at the metal centre (Fig. S33, $\mathrm{SI}$ ). ${ }^{12}$

In the case of the proligand $\mathbf{1} \mathbf{c H}_{\mathbf{2}}$, the reaction with one equivalent of tetrabenzylzirconium led to a mixture of products among which two binuclear complexes $\mathbf{2 c}$ (major) and $\mathbf{2} \mathbf{c}^{\prime}$ as well as one mononuclear complex $\mathbf{2 c}$ " (Scheme 4). Complex 2c, which features two tris(benzyl)zirconium fragments bridged by one phosphasalen ligand, was independently prepared from 


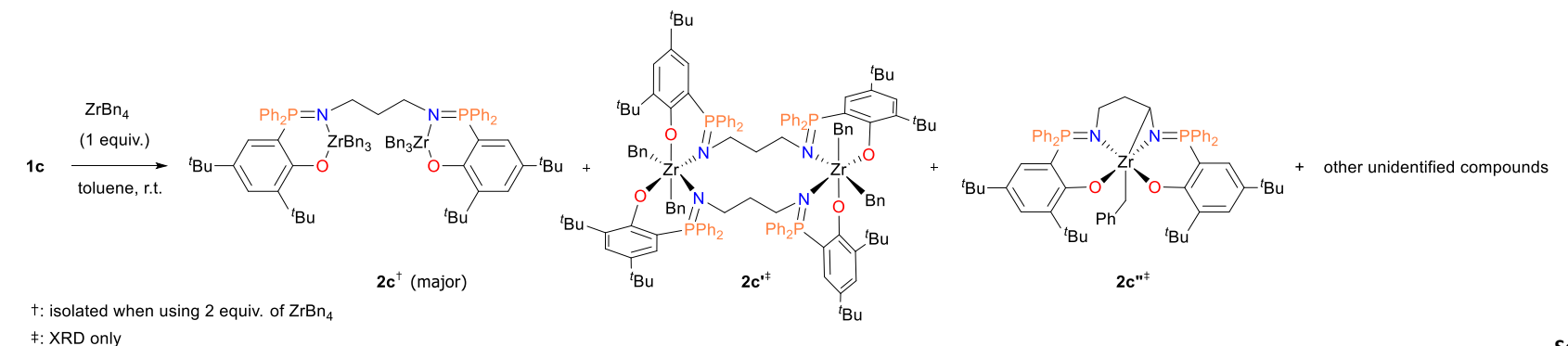

F: XRD only

$1 \mathbf{c H}_{2}$ and two equivalents of $\mathrm{Zr}\left(\mathrm{CH}_{2} \mathrm{Ph}\right)_{4}$ and isolated in $59 \%$ yield. ${ }^{13}$ Two characteristic ${ }^{t} \mathrm{Bu}$ signals at $\delta=1.51$ and $1.22 \mathrm{ppm}$ integrating for 18 protons each and one benzylic methylene signal at $\delta=1.83 \mathrm{ppm}$ integrating for 12 protons can be observed in the ${ }^{1} \mathrm{H}$ NMR spectrum of $2 \mathrm{c}$. The ${ }^{31} \mathrm{P}\left\{{ }^{1} \mathrm{H}\right\}$ NMR spectrum shows a signal at $\delta=30.8 \mathrm{ppm}$. Complexes $\mathbf{2 \mathbf { c } ^ { \prime }}$ and $\mathbf{2 \mathrm { c } ^ { \prime \prime }}$ could be identified by $X$-ray diffraction analysis of single crystals. In complex 2 $\mathbf{c}^{\prime}$, a second phosphasalen ligand bridges the two $\mathrm{Zr}$ centres giving a centrosymmetric binuclear complex with both $\mathrm{Zr}$ atoms in a pseudo-octahedral geometry where the coordinating atoms of the same nature $(C, C),(N, N)$ and $(O, O)$ are located cis to one another (Figure 6). Complex $\mathbf{2} \mathbf{c}^{\prime \prime}$ is a mononuclear complex with only one benzyl group present and the phosphasalen ligand coordinated in an unusual pentadentate fashion by the four ONNO atoms and by one $\mathrm{C}$ atom of the propylene linker (Figure 7). Complex $\mathbf{2} c^{\prime \prime}$ is best

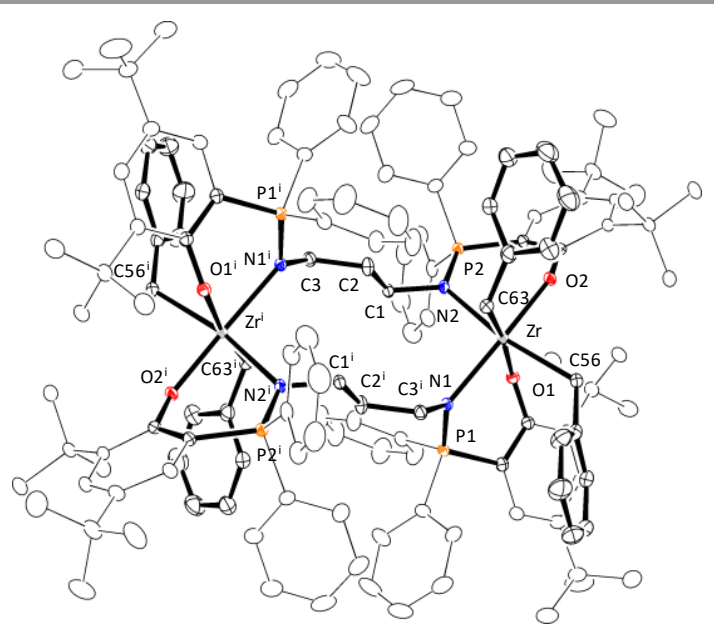

Figure 6 ORTEP view of complex $\mathbf{2} \mathbf{c}^{\prime}$ (hydrogen atoms are omitted for clarity). Selected distances (Å) and angles (deg): N1-P1 1.630(2), N1-Zr 2.289(2), N2-P2 1.614(2), N2-Zr 2.295(2), O1-Zr 2.0840(19), O2-Zr 2.0370(18), N1-Zr-N2 94.87(8), O2-Zr-O1 95.76(7), C63-Zr-C56 87.45(10). '1-X, 1-Y, 1-Z.

described as a pseudo-square pyramidal complex with the remaining benzyl ligand in apical position and one of the basal positions occupied by two atoms (N2 and $\mathrm{C} 1$ ) which form a small acute $\mathrm{N} 2-\mathrm{Zr}-\mathrm{C} 1$ angle of $38.27^{\circ}(11)$. The formation of $\mathbf{2 c}$ probably involves an entropically favored (toluene is liberated) $\sigma$-bond metathesis reaction between the $\mathrm{C}-\mathrm{H}$ bond $\alpha$ to $\mathrm{N}$ and the $\mathrm{Zr}$ - $\mathrm{C}$ bond of the benzyl moiety. ${ }^{14}$ Thus, the greater flexibility of ligand 2c brought by the extra carbon spacer favours binuclear complexes formation and/or side reactions at the propylene backbone.

Alkoxide derivatives were then targeted for use as lactide ROP initiators. Complexes $\mathbf{3} \mathbf{a}$ and $\mathbf{3} \mathbf{b}$ could be readily prepared by adding two equivalents of ${ }^{i} \mathrm{PrOH}$ to dichloromethane solutions of $\mathbf{2} \mathbf{a}$ and $\mathbf{2} \mathbf{b}$, respectively (Scheme 5 ). The NMR spectroscopic characterization of $\mathbf{3} \mathbf{a}$ and $\mathbf{3} \mathbf{b}$ revealed that both complexes are fluxional in solution and form as mixtures of trans and cis- $\beta$ isomers. In the ${ }^{1} \mathrm{H}$ NMR spectrum of $3 a\left(\mathrm{CD}_{2} \mathrm{Cl}_{2}, 250 \mathrm{~K}\right)$, isopropoxy groups resonances consist of a heptet at $\delta=3.70$ ppm for the trans isomer and a set of two heptets at $\delta=4.60$ and $3.23 \mathrm{ppm}$ for the cis- $\beta$ isomer with integrations corresponding to a trans:cis- $\beta$ ratio of $1: 4$. The ${ }^{31} \mathrm{P}\left\{{ }^{1} \mathrm{H}\right\} \mathrm{NMR}$ spectrum of 3a recorded under the same conditions displays a

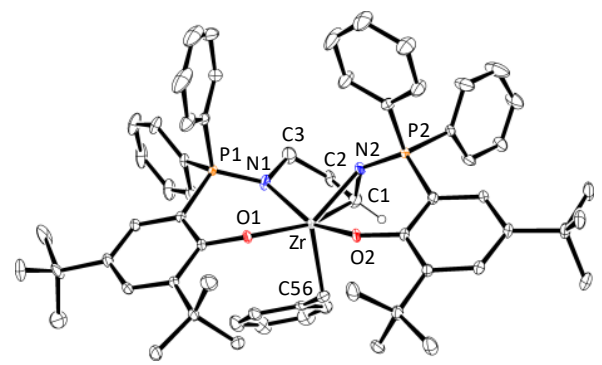

Figure 7 ORTEP view of complex $\mathbf{2} \mathrm{c}^{\text {" }}$ (hydrogen atoms are omitted for clarity except on C1). Selected distances ( $\AA$ ) and angles (deg): Zr-01 2.0717(19), Zr-02 2.064(2), Zr-N1 2.248(3), Zr-N2 2.193(2), Zr-C1 2.207(4), Zr-C56 2.282(3), P1-N1 1.593(2), P2-N2 1.583(2), O1-Zr-O2 97.13(8), N1-Zr-N2 81.50(9), C1-Zr-C56 85.90(12).

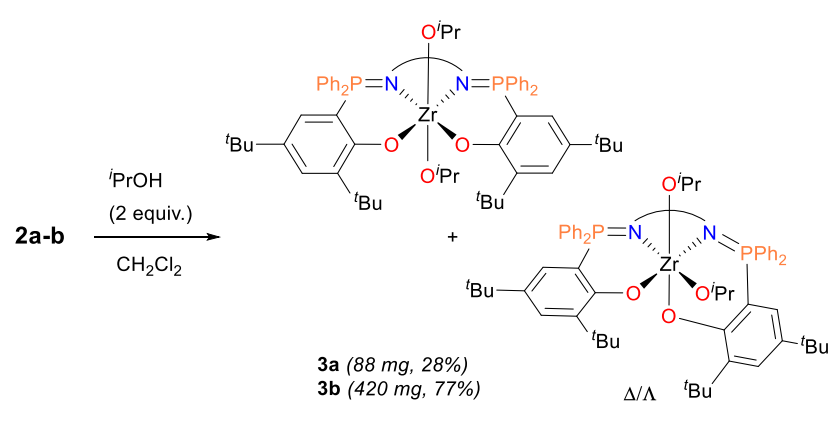

Scheme 5

signal at $\delta=32.7 \mathrm{ppm}$ for the trans isomer and a set of two signals at $\delta=31.6$ and $29.6 \mathrm{ppm}$ for the cis- $\beta$ isomer. Similar characteristic signals can be found in the ${ }^{1} \mathrm{H}$ and ${ }^{31} \mathrm{P}\left\{{ }^{1} \mathrm{H}\right\}$ NMR 
spectra of $\mathbf{3 b}$ in $\mathrm{d}_{8}$-THF at $250 \mathrm{~K}$ with a different trans:cis- $\beta$ ratio of $1: 1$. Variable temperature experiments were conducted on $\mathbf{3 a}$ and $\mathbf{3 b}$ in $\mathrm{d}_{8}$-toluene and line broadening analysis revealed activation parameters for the $\Delta-\Lambda$ isomerisation of $\Delta H^{\ddagger}=63.7$ $( \pm 4.1) \mathrm{kJ} \mathrm{mol}^{-1}$ and $\Delta \mathrm{S}^{\ddagger}=6( \pm 13) \mathrm{J} \cdot \mathrm{mol}^{-1}$ for $3 \mathrm{a}$ and $\Delta \mathrm{H}^{\ddagger}=48.5$ $( \pm 4.6) \mathrm{kJ}^{\mathrm{mol}} \mathrm{m}^{-1}$ and $\Delta \mathrm{S}^{\ddagger}=-48( \pm 16) \mathrm{J} . \mathrm{mol}^{-1}$ for $\mathbf{3 b}$ (Fig. S52 and Fig. $\mathrm{S} 65, \mathrm{SI}) . \S \S$ The slightly positive entropy of activation for $\mathbf{3 a}$, as opposed to the negative values for complexes $\mathbf{2} \mathbf{b}$ and $\mathbf{3 b}$, might be indicative of a dissociation/recoordination mechanism for the ethylene-linked complex $\mathbf{3 a}$, whereas $\mathbf{2} \mathbf{b}$ and $\mathbf{3 b}$, with a more rigid phenylene linker, would isomerize via a Bailar twist process. ${ }^{15}$ It is worth noting that a partial and reversible cis- $\beta$ trans isomerization was also observed in complex 3a upon heating. Suitable crystals for X-Ray diffraction analysis of $\mathbf{3 a}$ and $\mathbf{3 b}$ were obtained by vapour diffusion of pentane into saturated $\mathrm{CH}_{2} \mathrm{Cl}_{2}$ solutions of the complexes. The ORTEP view of 3a shows the zirconium atom in a pseudo-octahedral environment with the phosphasalen ligand adopting a cis- $\beta$ coordination mode (Figure 8). As for the proligand, the phosphasalen ligand is able to undergo geometrical deformation, the phosphorus atom authorizing the fac-wrapping mode around the metal. Comparison with the salan and salalen-Zr complexes reported by Jones in the same cis- $\beta$ configuration shows that the coordination sphere is a little bit more congested with phosphasalen with shorter $\mathrm{Zr}-\mathrm{N}$ bond distances (by ca $0.1 \AA$ ) and

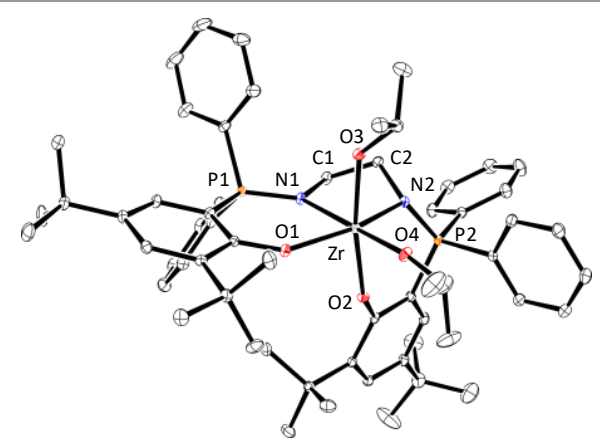

Figure 8 ORTEP view of complex 3 a (For the sake of clarity, $\mathrm{H}$ atoms as well as disorder and solvent molecules are not shown). Selected distances (Å) and angles (deg): N1-P1 1.601(2), N1-Zr 2.321(2), N2-P2 1.609(2), N2-Zr 2.286(2), O1-Zr 2.0424(17), O2-Zr 2.1236(17), O3-Zr 2.0095(17), O4-Zr 1.9586(17), O1-Zr-O2 92.67(7), N1-Zr-N2 73.89(7), O3-Zr-O4 92.43(7).

longer $\mathrm{Zr}-\mathrm{O}^{\mathrm{i} P r}$ distances (by ca $0.05 \AA$ A). ${ }^{6 \mathrm{~d}, 6 \mathrm{ff}}$ The solid state structure of $\mathbf{3 b}$ shows the complex in a distorted octahedral trans configuration with cis angles in the range 69.77(16)125.61(15) A (Figure 9). The phenylene linker is bent upward by $26.1(6)^{\circ}$ and the two aryloxy rings tilted downward (by $51.8(2)^{\circ}$ and $\left.49.4(2)^{\circ}\right)$ with respect to the mean coordination plane defined by $\mathrm{O} 1, \mathrm{~N} 1, \mathrm{~N} 2$ and $\mathrm{O} 2$. As a consequence, one of the two isopropoxy groups is sandwiched between the two aryloxy rings and short intramolecular $\mathrm{CH} / \pi$ interactions can be found. The $\mathrm{Zr}-\mathrm{O}$ and $\mathrm{Zr}-\mathrm{N}$ bond lengths are slightly longer by a value ranging from $0.051(4)$ to $0.073(5) \AA$ than those in complex 2a, also in trans configuration. $\mathrm{P}-\mathrm{N}$ bonds are slightly elongated $(0.022(5)$ $\AA ̊$ to $0.035(5) \AA$ ) compared to those in $\mathbf{1} \mathbf{b H}_{\mathbf{2}}$.

Considering that the $\mathrm{Zr}$ atom in these phosphasalen complexes is coordinatively saturated, which may limit the reactivity, we envisaged alternative cationic complexes with an open coordination site. We synthesized the cationic benzyl complexes $\mathbf{4 a}$ and $\mathbf{4 b}$ by addition of tris(pentafluorophenyl)borane to the dibenzyl complexes 2a and $\mathbf{2 b}$ (scheme 6). NMR and EA analysis confirmed the formation of the cations as a single product. The ${ }^{31} \mathrm{P}\left\{{ }^{1} \mathrm{H}\right\} N M R$ spectrum of 4 a shows one signal at $\delta=38.2 \mathrm{ppm}$ downfield shifted with respect to its neutral counterpart. The ${ }^{1} \mathrm{H}$ NMR spectrum displays two ${ }^{t} \mathrm{Bu}$ peaks at $\delta=1.10$ and $1.57 \mathrm{ppm}$, and two signals integrating each for two protons for the benzyl groups on zirconium and boron $(\delta=2.02$ and $2.78 \mathrm{ppm}$, respectively). The ethylene spacer protons appear as a poorly resolved multiplet which simplifies to a signal corresponding to an $\mathrm{AA}^{\prime} \mathrm{BB}^{\prime}$ system upon ${ }^{31} \mathrm{P}$ decoupling of the spectrum. All these

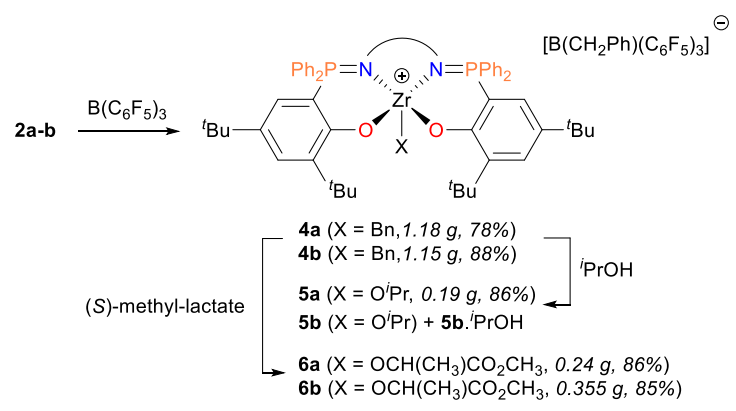

Scheme 6

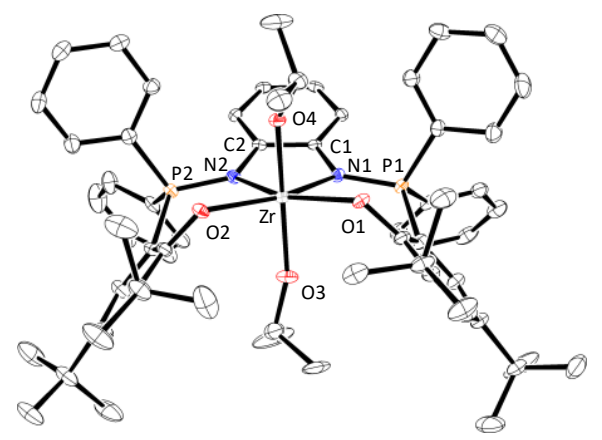

Figure $\mathbf{9}$ ORTEP view of complex $\mathbf{3 b}$ (For the sake of clarity, $\mathrm{H}$ atoms as well as disorder and solvent molecules are not shown). Selected distances ( $\AA$ ) and angles (deg): N1-P1 1.608(5), N1-Zr 2.276(5), N2-P2 1.614(5), N2-Zr 2.269(4), O1-Zr 2.125(4), O2-Zr 2.109(4), O3-Zr 1.956(4), O4-Zr 1.979(4), N1-Zr-N2 69.77(16), 01-Zr-O2 125.61(15), O3-Zr-04 164.94(18).

observations are consistent with a $C_{\mathrm{s}}$-symmetry in solution for 4a. Complex 4b showed similar NMR patterns. Cationic alkoxyde complexes $\mathbf{5 a - 5 b}$ and $\mathbf{6 a - 6} \mathbf{b}$ were next synthesized via an alcoholysis route using either one equivalent of isopropanol or one equivalent of $(S)$-methyl-lactate. NMR characterization revealed that $\mathbf{5 a}, \mathbf{6 a}$ and $\mathbf{6 b}$ have formed as a single product whereas $\mathbf{5 b}$ was contaminated by $15 \%$ of an impurity, which was identified as an isopropanol adduct $\mathbf{5 b}$-iPrOH (Fig. S94-S96, $\mathrm{SI})$. The ${ }^{31} \mathrm{P}\left\{{ }^{1} \mathrm{H}\right\}$ NMR spectrum of $\mathbf{5 a}$ displays one signal at $\delta=$ $37.0 \mathrm{ppm}$ reasonably downfield shifted with respect to those of 3a. The ${ }^{1} \mathrm{H}$ NMR spectrum is comparable to that of $4 a$ with the signals corresponding to the isopropoxy group replacing those of the benzyl group. The ${ }^{31} \mathrm{P}\left\{{ }^{1} \mathrm{H}\right\}$ NMR spectra of $\mathbf{6 a}$ and $\mathbf{6} \mathbf{b}$ are similar showing only two sharp singlets $\left(v_{1 / 2} \approx 3 \mathrm{~Hz}\right)$ of equal intensity at $\delta=35.7 / 35.5 \mathrm{ppm}$ and $33.1 / 31.6 \mathrm{ppm}$, respectively. The complexes $\mathbf{6 a}$ and $\mathbf{6} \mathbf{b}$ exhibit only two $\mathrm{CH}_{3}$ resonances for 
the methyl and methoxy groups of the lactate confirming the presence of only one species in solution. With regards to the geometry of the complexes, if the lactate were in $\mathbf{K}^{2}$ coordination mode, phosphasalen ligands would be necessary in cis- $\alpha$ or cis- $\beta$ wrapping. This would imply that complexes $\mathbf{6 a}$ and $\mathbf{6 b}$ are formed as a single diastereoisomer (out of six possible!). Considering that cis- $\beta$ wrapping creates highly asymmetric complexes, it should be reflected in NMR observables, which is not the case. For example, the ${ }^{13} \mathrm{C}$ NMR spectrum of $\mathbf{6 a}$ shows for the ethylene spacer a set of signals with reasonable shape symmetry composed of two doublets of doublets at $\delta=52.1$ and $51.9 \mathrm{ppm}$, respectively, with similar ${ }^{13} \mathrm{C}-{ }^{31} \mathrm{P}$ coupling constant values $\left({ }^{3} J_{\mathrm{CP}}=12.8 / 11.8 \mathrm{~Hz},{ }^{2} J_{\mathrm{CP}}=\right.$ 3.9/4.0 Hz). On the other hand, the ethylene spacer in $\mathbf{3 a}$ (cis- $\beta$ isomer) gives signals with different multiplicity and more distinct chemical shifts $\left\{\delta(\mathrm{ppm})=52.9\left(\mathrm{~d},{ }^{2} \mathrm{~J}_{\mathrm{PC}}=3.3 \mathrm{~Hz}\right), 50.1\right.$ $\left.\left(\mathrm{dd},{ }^{3} \mathrm{JPC}_{\mathrm{PC}}=18.2 \mathrm{~Hz},{ }^{2} \mathrm{JPC}_{\mathrm{PC}}=4.7 \mathrm{~Hz}\right)\right\}$. Additionally, the ${ }^{1} \mathrm{H} \mathrm{NMR}$ spectrum of 6a shows two multiplets at $\delta=3.48$ and $3.09 \mathrm{ppm}$ for the ethylene bridge whereas four well-distinct signals are observed in the case of $\mathbf{3 a}(\delta=3.90,2.80,2.68,2.55 \mathrm{ppm})$. On the other hand, a cis- $\alpha$ wrapping mode would lead to a pseudo $C_{2}$-symmetric complex but would require considerable distortion of the phosphasalen skeleton, which is also unlikely, especially for $\mathbf{6 b}$. It therefore rather suggests that $\mathbf{6 a}$ and $\mathbf{6 b}$ are five coordinated complexes with methyl-lactate in a $\mathrm{K}^{1-}$ coordination mode. Conversely, a downfield shift in ${ }^{13} \mathrm{C}$ NMR of the carbonyl carbon of the lactate ligand in complexes $6 a(\delta=$ $192.9 \mathrm{ppm})$ and $\mathbf{6 b}(\delta=192.8 \mathrm{ppm})$ with respect to methyl lactate $(\delta=176.1 \mathrm{ppm})$ is indicative of a coordination of the carbonyl to the $\mathrm{Zr}$ centre. ${ }^{16}$ This apparent inconsistency could be explained i) either by a hemilabile behavior of the lactate ligand in solution, giving rise to a fast equilibrium between a five- and six-coordinate metal centre as previously described for salen methyl lactate Al complexes; ${ }^{17}$ or ii) by an alternative coordination mode (i.e. not derived from cis- $\alpha$, cis- $\beta$ or trans geometries) displaying a pseudo $\mathrm{C}_{2}$ symmetry.

\section{Synthesis and characterization of the phosphasalen Ti complexes}

The ability of phosphasalen ligand to form $\mathrm{Zr}(\mathrm{IV})$ complexes being demonstrated we next turned our attention toward Ti. To

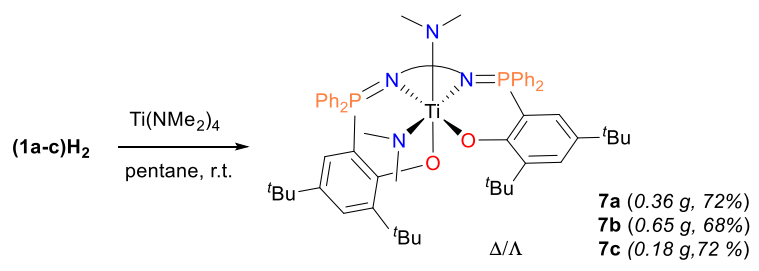

Scheme 7

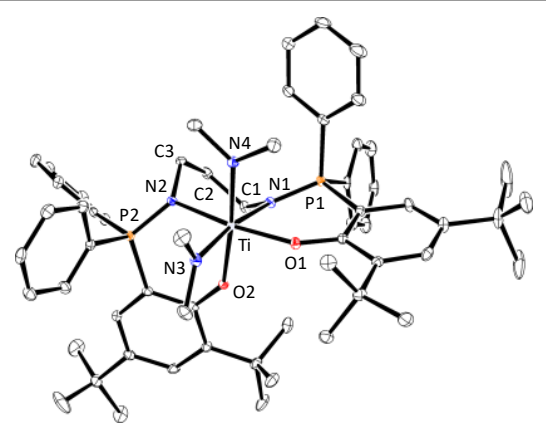

Figure 10 ORTEP view of complex 7c (hydrogen atoms are omitted for clarity). Selected distances (Å) and angles (deg): Ti-N1 2.247(2), Ti-N2 2.126(2), Ti-O1 1.9414(17), Ti-O2 2.0260(16), Ti-N3 1.951(2), Ti-N4 1.980(2), O1-Ti-O2 93.83(7), N1-Ti-N2 83.38(7), N3Ti-N4 94.91(9).

avoid the delicate and tedious synthesis of $\mathrm{Ti}\left(\mathrm{CH}_{2} \mathrm{Ph}\right)_{4}$, we used instead $\mathrm{Ti}\left(\mathrm{NMe}_{2}\right)_{4}$ also a priori suitable for undergoing protonolysis reaction with the phosphasalen proligands (1a-1c) $\mathbf{H}_{\mathbf{2}}$. The targeted bis(dimethylamido) phosphasalen $\mathrm{Ti}$ complexes $7 \mathrm{a}-\mathrm{c}$ were obtained as a single product in $68-72 \%$ yields (Scheme 7). Complexes 7a-c are not fluxional in solution on the NMR-time scale. The ${ }^{31} \mathrm{P}\left\{{ }^{1} \mathrm{H}\right\}$ NMR spectra of complexes 7a-c recorded at $300 \mathrm{~K}$ show a set of two sharp peaks $\left(\Delta \mathrm{v}_{1 / 2}\right.$ $<6 \mathrm{~Hz})$ at $\delta=32.0 / 26.1,27.0 / 17.9$ and 34.4/30.3 ppm, respectively. The ${ }^{1} \mathrm{H}$ NMR spectra of 7a-c display four signals for the ${ }^{t} \mathrm{Bu}$ groups and two signals for the $\mathrm{NMe}_{2}$ ligands in the aliphatic region. It therefore appears that all three phosphasalen ligands wrap the metal in a cis- $\beta$ fashion and that they are locked in solution. Single crystal diffraction analysis confirmed that complex $7 \mathrm{c}$ adopts a cis- $\beta$ geometry (Figure 10 ). Complex 7c displays a pseudo-octahedral geometry with cis arrangement of the $\mathrm{NMe}_{2}$ ligands (N3-Ti-N4 $=94.91^{\circ}(9)$ ). The Ti$\mathrm{N} 1$ bond trans to the $\mathrm{NMe}_{2}$ ligand is longer than $\mathrm{Ti}-\mathrm{N} 2$ bond trans to the aryloxyligand (by $0.121(3) \AA$ ) and, to a lesser extent, the P1-N1 bond is shorter than the P2-N2 bond (by $0.017(3) \AA$ ).

\section{ROP of Lactide}

The phosphasalen $\mathrm{Ti}$ and $\mathrm{Zr}$ complexes $\mathbf{2} \mathbf{a}-\mathbf{7} \mathbf{a}$ and $\mathbf{2} \mathbf{b}-\mathbf{4 b}$ were tested as ROP initiators of rac-lactide. The results are compiled in Table 1. Both neutral Zr(IV) dibenzyl complexes $\mathbf{2 a}$ and $\mathbf{2 b}$ showed poor activity $\left(90{ }^{\circ} \mathrm{C}\right.$, toluene), though the ethylenebridged complex $\mathbf{2 a}$ led to PLA with higher molecular weight and better conversion after a shorter reaction time (entries 1-2). Likewise, the Ti diamido complex 6 a also exhibited poor activity (entry 5). Performing lactide ROP using $\mathbf{2} \mathbf{a}-\mathbf{2} \mathbf{b}$ in the presence of an alcohol source ('PrOH, 1 equiv) for in situ generation of a $\mathrm{M}$ O'Pr species led to ill-defined and broadly disperse materials. Both neutral diisoproxy $\mathbf{Z r}$ complexes $\mathbf{3} \mathbf{a}$ and $\mathbf{3 b}$ promote ROP of lactide in toluene at $90{ }^{\circ} \mathrm{C}$ to give oligomers with low conversions, as deduced from GPC and NMR data (entries 3-4). Comparison with literature values shows that the neutral phosphasalen $\mathrm{Zr}$ complexes display much lower ROP performances, whether regarding activity and ROP control, compared to the best systems described by Jones and Kol based on salalen ligands and the titanium-salen complexes reported by Gibson and Long. ${ }^{5 a, 6}$ This is likely due steric and electronic factors: $i$ ) the severe steric bulk of phosphasalen ligand certainly prevents effective lactide coordination/activation and thus 
subsequent ring-opening; ii) the strong electron-donating properties of the phosphasalen ligand may drastically quench the Lewis acidity of the metal center. With this in mind, we set out using coordinatively unsaturated cationic $\mathrm{Zr}$ (IV) benzyl/alkoxide complexes $\mathbf{4 a - b}, \mathbf{5} \mathbf{a}$ and $\mathbf{6} \mathbf{a}-\mathbf{b}$ as lactide ROP initiators. The use of discrete cationic metal complexes for promoting ROP of cyclic esters to enhance the electrophilicity of the metal and its reactivity is a well-established approach but remains little explored with group 4 metal complexes. ${ }^{18}$ Initial ROP tests using $\mathrm{Zr}-\mathrm{Bn}^{+}$cations $\mathbf{4 a}$ and $\mathbf{4 b}$ as initiators showed that the ethylene-bridged cation $\mathbf{4 a}$ efficiently polymerize lactide in toluene solution ( $86 \%$ conv. within $6 \mathrm{~h}$, toluene, 90 ${ }^{\circ} \mathrm{C}$ ), yet to afford ill-defined PLA material (GPC data with a bimodal distribution). The phenylene-bridged complex $\mathbf{4 b}$ is a less active ROP catalyst than 4a (entries 6-7, Table 1), indicating that the flexibility of the metal-chelate is beneficial to ROP activity. ${ }^{19}$ However, under bulk polymerization reactions (130 ${ }^{\circ} \mathrm{C}$, neat lactide; entries $9-10$, table 1 ), the more thermally robust phenylene-bridged $\mathbf{4 b}$ allowed the production of welldefined PLA according to GPC data.

Table 1 ROP of lactide mediated by phosphasalen Ti and Zr complexes ${ }^{\text {a }}$

\begin{tabular}{ccccccc} 
Entry & Cat. & $\mathrm{t}(\mathrm{h})$ & Conv. $(\%)^{\mathrm{b}}$ & $\begin{array}{c}\mathrm{Mn}_{\mathrm{n}, \exp ^{\mathrm{c}}} \\
\left(\mathrm{g} \mathrm{mol}^{-1}\right)\end{array}$ & $\begin{array}{c}\mathrm{Mn}_{\mathrm{n}, \text { theo }}{ }^{\mathrm{d}} \\
\left(\mathrm{g} \mathrm{mol}^{-1}\right)\end{array}$ & $\bigoplus^{\mathrm{e}}$ \\
\hline 1 & $\mathbf{2 a}$ & 6 & 34 & 2835 & 4900 & 1.34 \\
2 & $\mathbf{2 b}$ & 24 & 10 & 425 & 1441 & 1.03 \\
3 & $\mathbf{3 a}$ & 24 & 22 & 430 & 3171 & 1.11 \\
4 & $\mathbf{3 b}$ & 24 & 15 & 505 & 2162 & 1.11 \\
5 & $\mathbf{7 a}$ & 24 & 35 & 578 & 5045 & 1.35 \\
6 & $\mathbf{4 a}$ & 6 & 86 & $13370^{\mathrm{f}}$ & 12395 & -- \\
7 & $\mathbf{4 b}$ & 24 & 60 & $5150^{f}$ & 8648 & -- \\
$8^{\mathrm{g}}$ & $\mathbf{2 a}$ & 4 & 76 & 700 & 10960 & -- \\
$9^{\mathrm{g}}$ & $\mathbf{4 a}$ & 1 & 78 & $27460^{\mathrm{f}}$ & 11250 & -- \\
$10^{\mathrm{g}}$ & $\mathbf{4 b}$ & 4 & 92 & 16060 & 13260 & 1.42 \\
$11^{\mathrm{i}}$ & $\mathbf{5 a}$ & 14 & 98 & 12000 & 14130 & 1.10 \\
$12^{\mathrm{h}}$ & $\mathbf{5 a}$ & 15 & 93 & 9840 & 13404 & 1.20 \\
$13^{\mathrm{i}}$ & $\mathbf{6 a}$ & 14 & 99 & 11000 & 14250 & 1.07 \\
$14^{\mathrm{h}}$ & $\mathbf{6 b}$ & 15 & 32 & 5820 & 4610 & 1.09
\end{tabular}

a Polymerization conditions: $[\text { rac-LA }]_{0}=1 \mathrm{M}, 100$ equiv of rac-LA, 1 equiv of metal catalyst, toluene, $90{ }^{\circ} \mathrm{C} .{ }^{b}$ Monomer conversion. ${ }^{c}$ Measured by GPC in THF $\left(30^{\circ} \mathrm{C}\right)$ using PS standards and corrected by applying the appropriate correcting factor (0.58). ${ }^{d}$ Calculated using $\mathrm{M}_{n \text {,theo }}=[\mathrm{rac}-\mathrm{LA}]_{0} /[\text { catalyst }]_{0} \times \mathrm{M}_{\mathrm{LA}} \times$ conversion. $e$ Measured by GPC in THF $\left(30^{\circ} \mathrm{C}\right) .{ }^{f}$ bimodal distribution. ${ }^{g}$ Bulk polymerisation conditions (100 equiv of rac-LA, $130{ }^{\circ} \mathrm{C}$ ). ${ }^{h}$ Reaction performed at $70^{\circ} \mathrm{C} .{ }^{\prime}$ Reaction duration not optimized.

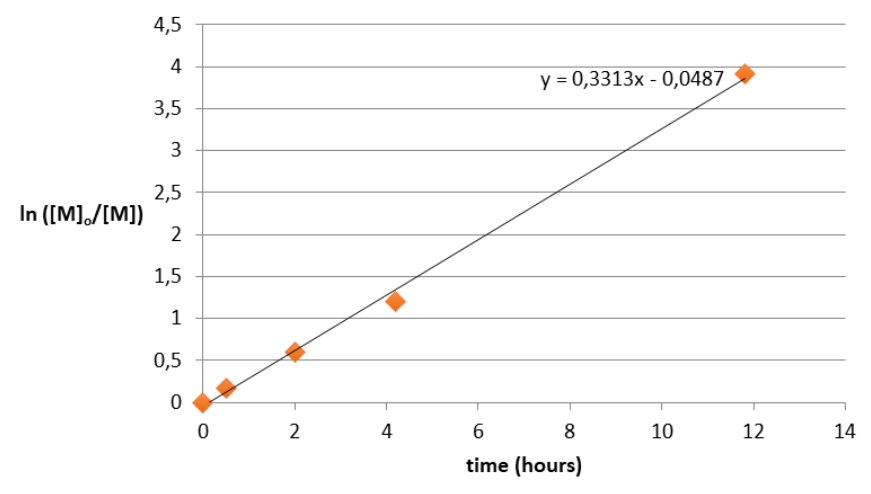

Figure 11. Plot of $\ln \left([\mathrm{M}]_{0} /[\mathrm{M}]\right)$ versus time for the ROP of rac-lactide mediated by initiator $5 \mathbf{a}(\mathrm{M}=$ monomer $)$. Conditions: $[\mathrm{M}]_{0}=1 \mathrm{M},[\mathrm{M}]_{0} /[5 \mathrm{a}]_{0}=100$, toluene, $90^{\circ} \mathrm{C}$.

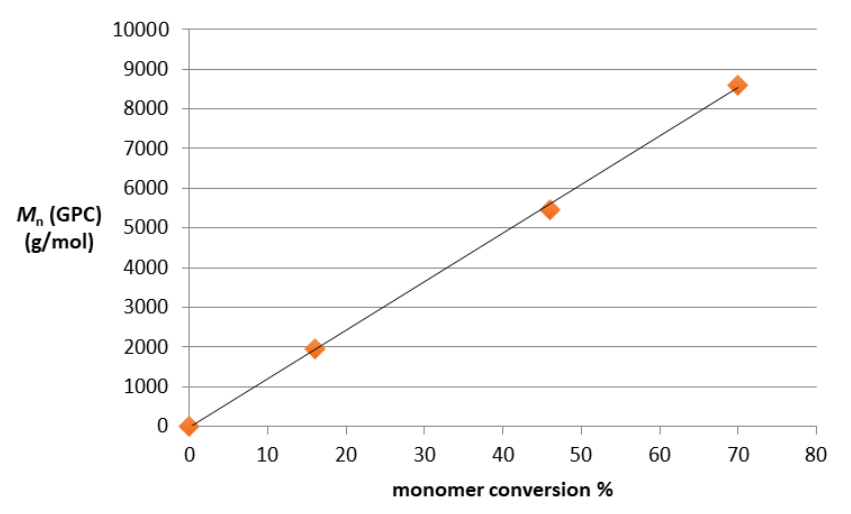

Figure 12. Plot of Mn (GPC) of PLA versus monomer conversion for the ROP of rac-lactide mediated by initiator $5 \mathrm{a}$. Conditions: : $[\mathrm{M}]_{0}=1 \mathrm{M},[\mathrm{M}]_{0} /[\mathbf{5 a}]_{0}=100$, toluene, $90^{\circ} \mathrm{C}$.

The ROP tests with cations $\mathbf{4 a}$ and $\mathbf{4 b}$ (toluene, $90{ }^{\circ} \mathrm{C}$ ) in the presence of ${ }^{i} \mathrm{PrOH}$ ( 1 equiv), for in situ generation of $\mathbf{5 a}$ and $\mathbf{5 b}$, only led to the formation of oligomers. Satisfyingly, well-defined cationic $\mathrm{Zr}-\mathrm{O}^{\prime} \mathrm{Pr}$ and $\mathrm{Zr}$-lactate complexes $\mathbf{5 a}$ and $\mathbf{6 a - b}$ turned out to be more active and well-behaved lactide ROP catalysts (entries $11-14$, Table 1$)$. Thus, in toluene $\left(70\right.$ or $90^{\circ} \mathrm{C}$ ), the $\mathrm{Zr}-$ $\mathrm{OiPr}^{+}$cation 5 a mediated the ROP of rac-lactide ( 100 equiv) to quantitatively afford chain-length controlled and narrow disperse PLA, as deduced from GPC and ${ }^{1} \mathrm{H}$ NMR data. Kinetic data and PLA characterization agree with a well-behaved ROP process proceeding through a coordination-insertion mechanism. These data include: i) an observed pseudo-first order in monomer (Figure 11), ii) a linear correlation between the PLA $M_{\mathrm{n}}$ values and monomer conversion as the ROP proceeds (Figure 12) and iii) MALDI-TOF MS data for PLA in line with GPC-estimated values, consistent with the presence an OiPr group at the ester end and marginal transesterifications during the ROP (Fig. S145-S147, SI). Thus, due to a more electrophilic metal and a less sterically hindered metal centre, the ROP activity of cation $\mathbf{5 a}$ is far superior to those of its neutral di-alkoxide counterpart 3a. It gets close to the performances of the best salen, salalen and salan group IV metal complexes but does not compare with other phosphasalen pentacoordinate yttrium and indium catalysts. ${ }^{6,8}$ In regards to the stereoselectivity of the ROP of rac-LA, it should be noted that cation 5a produced PLA moderately heterotactic $\left(P_{r}=0.63\right.$ for the ROP test conducted at $\left.90^{\circ} \mathrm{C}\right)$. With a similar activity to that of $\mathbf{5 a}$, the ethylene-bridged $\mathrm{Zr}$-(S)-Me-lactate cation $\mathbf{6 a}$ also efficiently catalyzed the controlled ROP of rac-LA with the production of narrow disperse and heterotactic-enriched PLA $\left(P_{\mathrm{r}}=0.71\right)$, as deduced from GPC and NMR analysis (Fig. S149$\mathrm{S} 150, \mathrm{SI})$. The phenylene-bridged $\mathbf{6 b}$ is much less active than 5a/6a in lactide ROP (entry 14 vs 12-13, Table 1), further reflecting the importance of a flexible ligand backbone for optimal ROP performances in these systems. The MALDI-TOF MS data of isolated PLA (from lactide ROP with $\mathbf{6 b}$ ) confirmed the presence of a Me-lactate moiety at the ester end of PLA and little transesterification reactions during the ROP process (Fig. 
S153, SI). This results implies a metal-controlled coordinationinsertion mechanism, distinct from the cationic zirconocenecatalyzed ROP of lactones that operates via an activated chain end mechanism (and through which the reactive site is moving away from the metal ion)..$^{18}$

\section{Conclusions}

Given the analogy between phosphasalen and salen, salalen or salan ligands and the efficacy of the latter with group IV metal ions in ROP of lactide, we set out to study the coordination chemistry of phosphasalen ligands toward $\mathrm{Ti}$ and $\mathrm{Zr}$ metal ions and to assess their performance in ROP catalysis. Phosphasalen have been found to be particularly suitable ligands for Ti and $\mathrm{Zr}$ ions giving rise to a variety of complexes. X-Ray diffraction studies coupled with NMR studies showed that phosphasalen can wrap the early metal ions in trans or cis- $\beta$ geometry. These results highlight the superior ability of phosphasalen to withstand geometrical deformation compared to salen and to create out-of-plane coordination of the metal. Most importantly, a series of discrete mononuclear cationic phosphasalen $\mathrm{Zr}$ complexes has been isolated and characterized. Advantage was thus taken from the strong electron donating properties of phosphasalen ligand for stabilizing cationic coordinatively unsaturated $\mathrm{Zr}$ species. With respect to lactide polymerization activity, the neutral phosphasalen $\mathrm{Ti}$ and $\mathrm{Zr}$ complexes were found poorly active in lactide ROP catalysis, which can be attributed to the encumbered and electron donating nature of the phosphasalen ligand. On the other hand, a much superior ROP activity was achieved with cationic $\mathrm{Zr}$ alkoxy complexes affording heterotactic-enriched PLA with controlled molecular weight and narrow polydispersities. To the best of our knowledge, this is the first example of a stereocontrolled ROP of lactide with a cationic group IV metal complex. The ROP process was shown to proceed through a coordination-insertion mechanism, which authorizes further development of the phosphasalen platform for the identification of robust and stereoselective cationic group IV metal catalysts for the ROP of cyclic esters.

\section{Experimental section}

\section{Reagents and conditions}

All reactions were carried out under $\mathrm{Ar}$ using conventional Schlenk techniques or in an Ar glovebox. Toluene, $\mathrm{CH}_{2} \mathrm{Cl}_{2}, \mathrm{Et}_{2} \mathrm{O}$, pentane and THF were dried using an MBraun MB SPS-800 solvent purification system. Bromobenzene was distilled over $\mathrm{CaH}_{2}$ and stored over activated $3 \AA$ molecular sieves in the glovebox. Deuterated solvents were dried by passage through a short column of activated neutral alumina (Brockman grade II) and stored over activated $3 \AA \AA$ molecular sieves in the glovebox, either at room temperature $\left(C_{6} D_{6}, C_{6} D_{5} B r \ldots\right)$ or at $-18^{\circ} \mathrm{C}\left(d_{8}-\mathrm{THF}\right.$, $\left.\mathrm{CD}_{2} \mathrm{Cl}_{2} \ldots\right)$. Alumina and molecular sieves were activated by heating for at least 6 hours above $230^{\circ} \mathrm{C}$ under vacuum. Diatomaceous earth (dicalite) was dried in an oven at $110^{\circ} \mathrm{C}$. Compound $\mathrm{Zr}\left(\mathrm{CH}_{2} \mathrm{Ph}\right)_{4}$ was prepared according to literature procedures. ${ }^{20}$ All other reagents were commercially available and used as received.

\section{Analyses}

The identity and purity of the compounds were established using elemental analysis, high-resolution mass spectrometry (ESI-MS), X-ray diffraction analysis, cyclic voltammetry, NMR, EPR and UV-vis spectroscopies. Some elemental analyses were performed by Mr. Stephen Boyer (London Metropolitan University). All other analyses were performed using analytical equipement of the Plateforme d'Analyse de l'Institut de Chimie Moléculaire de I'Université de Bourgogne (Ms Marie-José Penouilh-Suzette: ESI-MS; Mr Marcel Soustelle: elemental analyses). NMR spectra $\left({ }^{1} \mathrm{H},{ }^{11} \mathrm{~B},{ }^{13} \mathrm{C},{ }^{19} \mathrm{~F},{ }^{31} \mathrm{P}\right)$ were recorded on Bruker AV500 and AV600 spectrometers. NMR spectroscopy chemical shifts are quoted in parts per million $(\delta)$ relative to TMS (for ${ }^{1} \mathrm{H}$ and ${ }^{13} \mathrm{C}$ ), $\mathrm{BF}_{3} \cdot \mathrm{Et}_{2} \mathrm{O}$ (for ${ }^{11} \mathrm{~B}$ and ${ }^{19} \mathrm{~F}$ ) or $\mathrm{H}_{3} \mathrm{PO}_{4}$ (for ${ }^{31} \mathrm{P}$ ). For ${ }^{1} \mathrm{H}$ and ${ }^{13} \mathrm{C}$ spectra, values were determined by using solvent residual signals (e.g. $\mathrm{CDHCl}_{2}$ in $\mathrm{CD}_{2} \mathrm{Cl}_{2}$ ) as internal standards. ${ }^{21}$ The ${ }^{31} \mathrm{P},{ }^{19} \mathrm{~F}$ and ${ }^{11} \mathrm{~B}$ NMR spectra were referenced according to IUPAC recommendations (Absolute referencing).

Ring nomenclature: the positions of carbon and hydrogen atoms in the aromatic rings were labelled according to the following Figure. Where applicable, the phenyl rings of the diphenylphosphino moiety are differentiated in chiral compounds ( $\left.\mathrm{PPh}^{1}, \mathrm{PPh}^{2}\right)$.
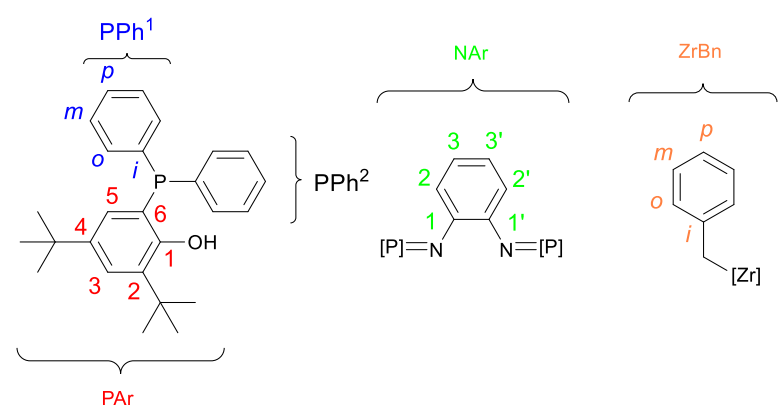

The number-average, weight-average molar masses $\left(M_{n}\right.$ and $M_{w}$, respectively) and molar mass distribution $\left(M_{w} / M_{n}\right)$ of PLA samples were determined by gel permeation chromatography (GPC) at $30{ }^{\circ} \mathrm{C}$ with Shimadzu LC20AD ultra-fast liquid chromatography equipped with a Shimadzu RID10A refractometer detector. Tetrahydrofuran (THF) was used as the eluent and the flow rate was set up at $1.0 \mathrm{~mL} / \mathrm{min}$. A Varian PLGel pre-column and a Varian PLGel $5 \mu \mathrm{m}$ were used. Calibrations were performed using polystyrene standards (400$100000 \mathrm{~g} / \mathrm{mol}$ ) and raw values of $M_{n}$ values $\left(M_{n, \mathrm{GPC}}\right)$ were thus obtained. Mass spectra were acquired on a time-of-light mass spectrometer (MALDI-TOF-TOF-Autoflex II TOF-TOF, Brucker Daltonics, Bremen, Germany) equipped with a nitrogen laser ( $\lambda$ $=337 \mathrm{~nm}$ ) at the "Service de Spectrométrie de Masse de I'Institut de Chimie de Strasbourg " and run in a positive mode. An external multi-point calibration was carried out before each measurement using the singly charged peaks of a standard peptide mixture $(0.4 \mu \mathrm{m}$ in water acidified with FlewAnalysis 3.0 software). $\alpha$-cyano-4-hydroxy-cinnamic acid (CHCA) was obtained from Sigma (St Louis, MO, USA) and 1,8, 9anthracenetriol (dithranol) from Alfa Aesar (Karlsruhe, 
Germany). Matrix solutions were fleshly prepared: CHCA was dissolved to saturation in $\mathrm{H}_{2} \mathrm{O}, \mathrm{CH}_{3} \mathrm{CN}, \mathrm{HCOOH}(50 / 50.1 \%)$ solution and dithranol to saturation in THF. Typically, a $1 / 1$ mixture of the sample solution in $\mathrm{CH}_{2} \mathrm{Cl}_{2}$ was mixed with the matrix solution and $0.5 \mu \mathrm{L}$ of the resulting mixture was deposed on the stainless plate.

\section{X-ray diffraction analyses}

Crystals of all compound were selected and mounted on a mylar loop with oil on a 'Bruker APEX-II CCD' or a 'Bruker D8 venture Photon 100' diffractometer. Crystal were kept at $115 \mathrm{~K}$ or $100 \mathrm{~K}$ during data collection. Using Olex2,22 the structures were solved with the ShelXT ${ }^{23}$ structure solution program using Direct Methods and refined with the $\mathrm{XL}^{24}$ refinement package using Least Squares minimization. More details about crystals, data collections and refinements can be found in the Supporting Information and in the Crystallographic Information Files in which are included .res and .hkl files.

\section{Synthesis of compounds}

For the syntheses of the proligands $(\mathbf{1} \mathbf{a}-\mathbf{c}) \mathbf{H}_{\mathbf{2}}$ not included here, see the Supporting Information.

\section{Synthesis of complex $2 a$}

Ligand $1 \mathrm{aH}_{2}(1.155 \mathrm{~g}, 1.38 \mathrm{mmol})$ and tetrabenzylzirconium $(0.630 \mathrm{~g}, 1.38 \mathrm{mmol})$ were dissolved in toluene $(15 \mathrm{~mL})$ and stirred for $10 \mathrm{~min}$. The volatiles were removed under vacuum, and the residue was suspended in hexane $(10 \mathrm{~mL})$. The resulting solid was filtered and washed with hexane $(4 \times 2 \mathrm{~mL})$ to give $2 \mathrm{a}$ as a yellow powder $(1.263 \mathrm{~g}, 80 \%) .{ }^{31} \mathrm{P}\left\{{ }^{1} \mathrm{H}\right\} \mathrm{NMR}\left(202 \mathrm{MHz}, \mathrm{C}_{6} \mathrm{D}_{6}\right.$, $300 \mathrm{~K}): \delta=36.5\left(\mathrm{v}_{1 / 2} \approx 4 \mathrm{~Hz}\right) .{ }^{1} \mathrm{H}$ NMR $\left(500 \mathrm{MHz}, \mathrm{C}_{6} \mathrm{D}_{6}, 300 \mathrm{~K}\right): \delta$ $=7.82\left(\mathrm{~d}, 2 \mathrm{H},{ }^{4} \mathrm{~J}_{\mathrm{HH}}=2.10 \mathrm{~Hz}, \mathrm{H} 3\right.$ of PAr $), 7.30-7.22(\mathrm{~m}, 8 \mathrm{H}, \mathrm{o}$ of $\left.\mathrm{PPh}_{2}\right), 7.12-7.07\left(\mathrm{~m}, 12 \mathrm{H}\right.$, overlapping $m$ and $p$ of $\left.\mathrm{PPh}_{2}\right), 6.74(\mathrm{~m}$, $4 \mathrm{H}, m$ of $\mathrm{ZrBn}), 6.65\left(\mathrm{dd},{ }^{3} \mathrm{JH}_{\mathrm{PH}}=16.0 \mathrm{~Hz},{ }^{4} J_{\mathrm{HH}}=2.1 \mathrm{~Hz}, 2 \mathrm{H}, \mathrm{H} 5\right.$ of PAr), $6.56(\mathrm{~m}, 2 \mathrm{H}, p$ of $\mathrm{ZrBn}), 6.13(\mathrm{~m}, 4 \mathrm{H}, o$ of $\mathrm{ZrBn}), 3.15(\mathrm{~m}$, $\left.4 \mathrm{H}, \mathrm{NCH}_{2}\right), 2.36\left(\mathrm{~s}, 4 \mathrm{H}, \mathrm{CH}_{2}\right.$ of $\left.\mathrm{ZrBn}\right), 1.96\left(\mathrm{~s}, 18 \mathrm{H}, \mathrm{CH}_{3}\right.$ of $\left.{ }^{t} \mathrm{Bu}^{2}\right)$, $1.13\left(\mathrm{~s}, 18 \mathrm{H}, \mathrm{CH}_{3}\right.$ of $\left.{ }^{t} \mathrm{Bu}^{4}\right) .{ }^{13} \mathrm{C}\left\{{ }^{1} \mathrm{H}\right\}$ NMR $\left(126 \mathrm{MHz}, \mathrm{C}_{6} \mathrm{D}_{6}, 300 \mathrm{~K}\right)$ : $\delta=166.5\left(\mathrm{~d},{ }^{2} \mathrm{~J}_{\mathrm{PC}}=2.2 \mathrm{~Hz}, \mathrm{C} 1\right.$ of PAr), 155.9 (s, $i$ of $\left.\mathrm{ZrBn}\right), 138.9$ (d, ${ }^{3} J_{\mathrm{CP}}=7.2 \mathrm{~Hz}, \mathrm{C} 2$ of PAr), $138.4\left(\mathrm{~d},{ }^{3} \mathrm{~J}_{\mathrm{CP}}=15.4 \mathrm{~Hz}, \mathrm{C} 4\right.$ of PAr), $133.8\left(d,{ }^{2} J_{\mathrm{CP}}=9.9 \mathrm{~Hz}, o\right.$ of $\left.\mathrm{PPh}_{2}\right), 132.3\left(\mathrm{~s}, p\right.$ of $\left.\mathrm{PPh}_{2}\right), 129.8(\mathrm{~s}$, C3 of PAr), $129.1\left(\mathrm{~d},{ }^{3} J_{\mathrm{CP}}=12.1 \mathrm{~Hz}, m\right.$ of $\left.\mathrm{PPh}_{2}\right), 129.0\left(\mathrm{~d},{ }^{1} J_{\mathrm{CP}}=\right.$ $115.9 \mathrm{~Hz}$, $i$ of $\mathrm{PPh}_{2}$ ), 127.7 (d, ${ }^{2} J_{\mathrm{CP}}=14.9 \mathrm{~Hz}, \mathrm{C} 5$ of PAr), 127.5 (s, $m$ of $\mathrm{ZrBn}$ ), 125.5 (s, o of $\mathrm{ZrBn}$ ), 116.7 (s, $p$ of $\mathrm{ZrBn}$ ), 108.2 (d, ${ }^{1} \mathrm{JP}_{\mathrm{CP}}$ $=130.0 \mathrm{~Hz}, \mathrm{C} 6$ of PAr), 59.8 (s, $\mathrm{CH}_{2}$ of $\mathrm{ZrBn}$ ), 51.9 (dd, ${ }^{3} \mathrm{~J}_{\mathrm{CP}}=17.6$ $\left.\mathrm{Hz},{ }^{2} \mathrm{~J}_{\mathrm{CP}}=3.8 \mathrm{~Hz}, \mathrm{NCH}_{2}\right), 36.2\left(\mathrm{~s}, \mathrm{C}\right.$ of $\left.{ }^{t} \mathrm{Bu}^{2}\right), 34.3\left(\mathrm{~s}, \mathrm{C}\right.$ of $\left.{ }^{t} \mathrm{Bu}^{4}\right), 31.6$ (s, $\mathrm{CH}_{3}$ of $\left.{ }^{t} \mathrm{Bu}^{4}\right), 30.9$ (s, $\mathrm{CH}_{3}$ of ${ }^{t} \mathrm{Bu}^{2}$ ). Elemental Analysis: calculated for $\mathrm{C}_{68} \mathrm{H}_{78} \mathrm{~N}_{2} \mathrm{O}_{2} \mathrm{P} 2 \mathrm{Zr}$ : C, 73.68; $\mathrm{H}, 7.09 ; \mathrm{N}, 2.53$. Found: C, 73.17; H, 7.34; N, 2.20.

\section{Synthesis of complex $2 b$}

Ligand $\mathbf{1} \mathbf{b H}_{\mathbf{2}}(1.770 \mathrm{~g}, 2.00 \mathrm{mmol})$ and tetrabenzylzirconium ( $0.912 \mathrm{~g}, 2.00 \mathrm{mmol}$ ) were dissolved in dichloromethane (50 $\mathrm{mL}$ ) then stirred at room temperature for $3 \mathrm{~h} 30$, during which a yellow precipitate appeared. The suspension was filtered, and the solid was washed with dichloromethane $(3 \times 5 \mathrm{~mL})$ and dried under vacuum to give complex $\mathbf{2} \mathbf{b}$ containing 1.2 eq of $\mathrm{CH}_{2} \mathrm{Cl}_{2}$
(1.999 g, $80 \%)$. The mixture of isomers was characterized by multinuclear NMR in $\mathrm{d}_{8}$-THF at $210 \mathrm{~K}$ on a $500 \mathrm{MHz}$, spectrometer. Under these conditions, the cis- $\beta^{\Delta} /$ cis- $\beta^{\wedge}$ isomerisation was frozen. Some signals in the aromatic regions of ${ }^{1} \mathrm{H}$ and ${ }^{13} \mathrm{C}\left\{{ }^{1} \mathrm{H}\right\}$ NMR spectra could not be assigned, in which case they are labelled as $\mathrm{CH}$-Ar or $\mathrm{CH}-\mathrm{Ar} .{ }^{31} \mathrm{P}\left\{{ }^{1} \mathrm{H}\right\}$ NMR $(243$ MHz, $\left.\mathbf{d}_{8}-\mathrm{THF}, 210 \mathrm{~K}\right): \delta=30.5\left(\mathrm{~s}, \mathrm{v}_{1 / 2} \approx 3 \mathrm{~Hz}, \mathrm{P}(\beta)\right), 29.2\left(\mathrm{~s}, \mathrm{v}_{1 / 2} \approx\right.$ $4 \mathrm{~Hz}, \mathrm{P}(\mathrm{T})), 28.0\left(\mathrm{~s}, \mathrm{v}_{1 / 2} \approx 5 \mathrm{~Hz}, \mathrm{P}(\beta)\right) .{ }^{1} \mathbf{H}$ NMR $\left(600 \mathrm{MHz}, \mathbf{d}_{\mathbf{8}}\right.$-THF $210 \mathrm{~K}): \delta=7.83$ (m, 1H, CH-Ar), 7.75-7.63 (m, CH-Ar), 7.63-7.51 (m, CH-Ar overlapping with $\mathrm{H} 3$ of $\operatorname{PAr}(\mathrm{T})), 7.51-7.43(\mathrm{~m}, 1 \mathrm{H}+8 \mathrm{H}$, $H 3$ of $\operatorname{PAr}(\beta)$ overlapping with $o$ of $\operatorname{PAr}(\mathrm{T})), 7.31(\mathrm{~s}, 1 \mathrm{H}, H 3$ of $\operatorname{PAr}(\beta)), 7.23(\mathrm{~m}, \mathrm{CH}-\mathrm{Ar}), 7.08\left(\mathrm{~d}, 1 \mathrm{H}, 3 \mathrm{~J}_{\mathrm{PH}}=15.6 \mathrm{~Hz}, \mathrm{H} 5\right.$ of $\operatorname{PAr}(\beta)), 6.75(\mathrm{~m}, 2 \mathrm{H}, m$ of $\operatorname{ZrBn}(\beta)), 6.72-6.65(\mathrm{~m}, \mathrm{CH}-\mathrm{Ar}$ overlapping with $\mathrm{H} 5$ of $\operatorname{PAr}(\beta)), 6.65\left(\mathrm{~d}, 1 \mathrm{H},{ }^{3} \mathrm{~J}_{\mathrm{PH}}=15.0 \mathrm{~Hz}, \mathrm{H} 5\right.$ of $\operatorname{PAr}(\beta)$ overlapping with $\mathrm{CH}-\mathrm{Ar}), 6.56-6.38$ (m, $\mathrm{CH}-\mathrm{Ar}$ overlapping with $m$ of $\operatorname{ZrBn}(\mathrm{T}), m$ of $\operatorname{ZrBn}(\beta), H 2$ of $\operatorname{NAr}(\mathrm{T})$ and $p$ of $\operatorname{ZrBn}(\beta)), 6.52(\mathrm{~m}, 4 \mathrm{H}, m$ of $\operatorname{ZrBn}(\mathrm{T})), 6.46(\mathrm{~m}, 2 \mathrm{H}, m$ of $\operatorname{ZrBn}(\beta)), 6.40(\mathrm{~m}, 1 \mathrm{H}, p$ of $\operatorname{ZrBn}(\beta)), 6.35\left(\mathrm{~d},{ }^{3} \mathrm{~J}_{\mathrm{PH}}=15.7 \mathrm{~Hz}, \mathrm{H} 5\right.$ of $\operatorname{PAr}(\mathrm{T})), 6.31(\mathrm{~m}, 2 \mathrm{H}, p$ of $\mathrm{ZrBn}(\mathrm{T})), 6.22\left(\mathrm{t},{ }^{3} \mathrm{JHH}_{\mathrm{HH}}=8.0 \mathrm{~Hz}, \mathrm{H} 3\right.$ of $\operatorname{NAr}(\beta)$ overlapping with $p$ of $\operatorname{ZrBn}(\beta)), 6.18(\mathrm{~m}, 1 \mathrm{H}, p$ of $\operatorname{ZrBn}(\beta)$ overlapping with two $\mathrm{H} 3$ of $\operatorname{NAr}(\beta), \mathrm{H} 2$ of $\operatorname{NAr}(\beta)$ and $\mathrm{H} 3$ of $\operatorname{NAr}(\mathrm{T})), 6.18-6.10(\mathrm{~m}, 2+1 \mathrm{H}, H 3$ of $\operatorname{NAr}(\beta), H 2$ of $\operatorname{NAr}(\beta)$ and $H 3$ of $\operatorname{NAr}(T)$ overlapping with $p$ of $\operatorname{ZrBn}(\beta)), 6.01(\mathrm{~m}, 4 \mathrm{H}, o$ of $\operatorname{ZrBn}(\mathrm{T})), 5.77\left(\mathrm{~d},{ }^{3} J_{\mathrm{HH}}=8.0 \mathrm{~Hz}, 1 \mathrm{H}, \mathrm{H} 2\right.$ of $\left.\mathrm{NAr}(\beta)\right), 2.37\left(\mathrm{~d},{ }^{2} J_{\mathrm{HH}}=\right.$ $10.1 \mathrm{~Hz}, 1 \mathrm{H}, \mathrm{CH}_{2}$ of $\left.\mathrm{ZrBn}(\beta)\right), 2.09\left(\mathrm{~d},{ }^{2} J_{\mathrm{HH}}=8.3 \mathrm{~Hz}, 1 \mathrm{H}, \mathrm{CH}_{2}\right.$ of $\operatorname{ZrBn}(\beta)), 1.79\left(\mathrm{~d},{ }^{2} \mathrm{~J}_{\mathrm{HH}}=10.1 \mathrm{~Hz}, 1 \mathrm{H}, \mathrm{CH}_{2}\right.$ of $\left.\mathrm{ZrBn}(\beta)\right), 1.74(\mathrm{~s}, 4 \mathrm{H}$, $\mathrm{CH}_{2}$ of $\left.\mathrm{ZrBn}(\mathrm{T})\right), 1.67\left(\mathrm{~d},{ }^{2} \mathrm{~J}_{\mathrm{HH}}=8.3 \mathrm{~Hz}, 1 \mathrm{H}, \mathrm{CH}_{2}\right.$ of $\left.\mathrm{ZrBn}(\beta)\right), 1.42$ $\left(\mathrm{s}, 9 \mathrm{H}, \mathrm{CH}_{3}\right.$ of ${ }^{t} \mathrm{Bu}^{2}(\beta)$ ), 1.27 (s, 18H, $\mathrm{CH}_{3}$ of ${ }^{t} \mathrm{Bu}^{2}(\mathrm{~T})$ )), 1.18 (two s, $18 \mathrm{H}$, two overlapping $\mathrm{CH}_{3}$ of $\left.{ }^{t} \mathrm{Bu}^{4}(\beta)\right), 1.13\left(\mathrm{~s}, 18 \mathrm{H}, \mathrm{CH}_{3}\right.$ of $\left.{ }^{t} \mathrm{Bu}^{4}(\mathrm{~T})\right), 0.52\left(\mathrm{~s}, 9 \mathrm{H}, \mathrm{CH}_{3}\right.$ of $\left.{ }^{t} \mathrm{Bu}^{2}(\beta)\right) .{ }^{13} \mathrm{C}\left\{{ }^{1} \mathrm{H}\right\}$ NMR (150.9 MHz, $\mathbf{d}_{8}$-THF, $210 \mathrm{~K}$ ): $\delta=166.7$ (s, $C 1$ of $\left.\operatorname{PAr}(\mathrm{T})\right), 165.6(\mathrm{~s}, C 1$ of $\operatorname{PAr}(\beta))$ ), $163.0(\mathrm{~s}, C 1$ of $\operatorname{PAr}(\beta)), 154.7(\mathrm{~s}, i$ of $\operatorname{ZrBn}(\mathrm{T})), 154.5$ (s, $i$ of $\operatorname{ZrBn}(\beta)), 153.2(\mathrm{~s}, i$ of $\operatorname{ZrBn}(\beta)), 145.1\left(\mathrm{dd},{ }^{3} J_{\mathrm{PC}}=13.0 \mathrm{~Hz},{ }^{2} J_{\mathrm{PC}}=\right.$ $2.1 \mathrm{~Hz}, C 1$ of $\operatorname{NAr}(\beta)), 144.9\left(\mathrm{dd},{ }^{3} J_{\mathrm{PC}}=14.3 \mathrm{~Hz},{ }^{2} \mathrm{JPC}_{\mathrm{PC}}=2.8 \mathrm{~Hz}, \mathrm{C} 1\right.$ of $\operatorname{NAr}(\beta)), 142.3\left(d d,{ }^{3} J_{P C}=17.7 \mathrm{~Hz},{ }^{2} J_{P C}=2.7 \mathrm{~Hz}, C 1\right.$ of $\left.\operatorname{NAr}(T)\right)$, $139.9\left(\mathrm{~d},{ }^{3} J_{\mathrm{PC}}=15.1 \mathrm{~Hz}, C 4\right.$ of $\operatorname{PAr}(\beta)$ overlapping with $C 2$ of $\operatorname{PAr}(\beta)), 139.8\left(d,{ }^{3} J_{P C}=7.2 \mathrm{~Hz}, C 2\right.$ of $\operatorname{PAr}(\beta)$ overlapping with $C 4$ of $\operatorname{PAr}(\beta)), 138.7\left(\mathrm{~d},{ }^{3} \mathrm{~J}_{\mathrm{PC}}=6.1 \mathrm{~Hz}, C 2\right.$ of $\operatorname{PAr}(\beta)$ overlapping with C4 of $\operatorname{PAr}(\beta)), 138.7\left(\mathrm{~d},{ }^{3} \mathrm{JPC}_{\mathrm{PC}}=13.1 \mathrm{~Hz}, C 4\right.$ of $\operatorname{PAr}(\beta)$ overlapping with $C 2$ of $\operatorname{PAr}(\beta)), 138.2\left(\mathrm{~d},{ }^{3} \mathrm{~J}_{\mathrm{PC}}=15.4 \mathrm{~Hz}, C 4\right.$ of $\left.\operatorname{PAr}(\mathrm{T})\right), 138.0$ $\left(d,{ }^{3} J_{P C}=6.7 \mathrm{~Hz}, C 2\right.$ of $\left.\operatorname{PAr}(T)\right), 135.5\left(d, 2 J_{P C}=10.4 \mathrm{~Hz}, o\right.$ of $\left.\mathrm{PPh}_{2}(\beta)\right), 135.0\left(\mathrm{~d},{ }^{2} \mathrm{~J}_{\mathrm{PC}}=8.8 \mathrm{~Hz}\right.$, o of $\left.\mathrm{PPh}_{2}(\beta)\right), 134.5(\mathrm{~m}, p$ of $\left.\mathrm{PPh}_{2}(\beta)\right), 134.5$ (s, CH-Ar), 134.0 (d, ${ }^{2} J_{\mathrm{PC}}=9.9 \mathrm{~Hz}, o$ of $\mathrm{PPh}_{2}(\mathrm{~T})$ overlapping with $\mathrm{CH}-\mathrm{Ar}$ ), 133.9 (s, $\mathrm{CH}$-Ar overlapping with $O$ of $\mathrm{PPh}_{2}(\mathrm{~T})$ and $\mathrm{CH}-\mathrm{Ar}$ ), 133.8 (s, $\mathrm{CH}$-Ar overlapping with $\mathrm{CH}-\mathrm{Ar}$ ), 133.5 (s, CH-Ar), 132.9 (d, ${ }^{2} J_{\mathrm{PC}}=10.0 \mathrm{~Hz}$, o of $\left.\mathrm{PPh}_{2}(\beta)\right), 132.2$ (s, $\mathrm{CH}-\mathrm{Ar}$ ), $131.7\left(\mathrm{~d},{ }^{1} \mathrm{JPC}_{\mathrm{PC}} 89.6 \mathrm{~Hz}, i\right.$ of $\left.\mathrm{PPh}_{2}(\beta)\right), 130.6$ (s, C3 of PAr(T)), 130.4 (s, CH-Ar overlapping with CH-Ar), 130.3 (s, CH-Ar overlapping with $\mathrm{CH}-\mathrm{Ar}$ and $i$ of $\left.\mathrm{PPh}_{2}(\beta)\right), 130.3-129.7(\mathrm{~m}$, several overlapping $\mathrm{CH}$-Ar overlapping $i$ of $\left.\mathrm{PPh}_{2}(\beta)\right), 129.9$ (d, ${ }^{1} J_{\mathrm{PC}}=90.4 \mathrm{~Hz}, i$ of $\left.\mathrm{PPh}_{2}(\beta)\right), 129.2(\mathrm{~s}, C 3$ of $\operatorname{PAr}(\beta)), 129.1-128.8$ (m, overlapping $\mathrm{CH}-\mathrm{Ar}$ ), $128.4\left(\mathrm{~d},{ }^{2} \mathrm{~J}_{\mathrm{PC}}=15.4 \mathrm{~Hz}, \mathrm{C5}\right.$ of $\mathrm{PAr}(\beta)$ overlapping with $i$ of $\left.\mathrm{PPh}_{2}(\beta)\right), 128.2\left(\mathrm{~d},{ }^{1} \mathrm{~J}_{\mathrm{PC}}=89.8 \mathrm{~Hz}, i\right.$ of $\mathrm{PPh}_{2}(\beta)$ overlapping with $C 5$ of $\operatorname{PAr}(\beta)$ and $C 5$ of $\left.\operatorname{PAr}(\mathrm{T})\right), 127.9$ $\left(d,{ }^{2} J_{P C}=12.9 \mathrm{~Hz}, C 5\right.$ of $\operatorname{PAr}(\mathrm{T})$ overlapping with two $i$ of $\mathrm{PPh}_{2}(\beta)$ ), $127.8\left(\mathrm{~d},{ }^{1}{ }_{\mathrm{PC}}=72.4 \mathrm{~Hz}\right.$, $i$ of $\mathrm{PPh}_{2}(\beta)$ overlapping with $\mathrm{C} 5$ of $\mathrm{PAr}(\mathrm{T})$ and $m$ of $\operatorname{ZrBn}(\mathrm{T})$ ), 127.3 (s, $m$ of $\operatorname{ZrBn}(\mathrm{T})$ overlapping with $i$ of 
$\mathrm{PPh}_{2}(\beta)$ and $i$ of $\left.\mathrm{PPh}_{2}(\mathrm{~T})\right), 127.0$ (s, $m$ of $\mathrm{ZrBn}(\beta)$ overlapping with $i$ of $\left.\mathrm{PPh}_{2}(\mathrm{~T})\right), 126.9$ (s, $m$ of $\mathrm{ZrBn}(\beta)$ overlapping with $i$ of $\left.\mathrm{PPh}_{2}(\mathrm{~T})\right), 126.9\left(\mathrm{~d},{ }^{1}{ }_{\mathrm{PC}}=92.6 \mathrm{~Hz}, i\right.$ of $\mathrm{PPh}_{2}(\mathrm{~T})$ overlapping with two $m$ of $\operatorname{ZrBn}(\beta)), 126.5$ (s, o of $\operatorname{ZrBn}(\beta)), 125.8(\mathrm{~m}, o$ of $\mathrm{ZrBn}(\mathrm{T})$ overlapping with $o$ of $\mathrm{ZrBn}(\beta)), 124.4\left(\mathrm{~d},{ }^{3} \mathrm{~J}_{\mathrm{PC}}=6.0 \mathrm{~Hz}, \mathrm{C} 2\right.$ of $\operatorname{NAr}(\beta)), 122.2\left(\mathrm{~d}, 3_{\mathrm{PC}}=3.3 \mathrm{~Hz}, C 2\right.$ of $\left.\operatorname{NAr}(\beta)\right), 121.1(\mathrm{~s}, C 3$ of $\operatorname{NAr}(\beta)), 120.7\left(\mathrm{~d},{ }^{3} \mathrm{~J}_{\mathrm{PC}}=10.2 \mathrm{~Hz}, C 2\right.$ of $\left.\operatorname{NAr}(\mathrm{T})\right), 120.6$ (s, C3 of $\operatorname{NAr}(\beta)), 119.9$ (s, C3 of $\operatorname{NAr}(T)$ ), 118.1 (two overlapping $s, p$ of $\operatorname{ZrBn}(\beta)), 117.5(\mathrm{~s}, p$ of $\operatorname{ZrBn}(\mathrm{T})), 115.3\left(\mathrm{~d},{ }^{1}{ }_{\mathrm{PC}}=120.4 \mathrm{~Hz}, \mathrm{C} 6\right.$ of $\operatorname{PAr}(\mathrm{T})), 112.9\left(\mathrm{~d},{ }^{1} \mathrm{JPC}_{\mathrm{PC}}=118.0 \mathrm{~Hz}, \mathrm{C} 6\right.$ of $\left.\operatorname{PAr}(\beta)\right), 111.7\left(\mathrm{~d},{ }^{1} \mathrm{~J}_{\mathrm{PC}}=\right.$ $110.7 \mathrm{~Hz}, C 6$ of $\operatorname{PAr}(\beta)), 68.2$ (s, $\mathrm{CH}_{2}$ of $\left.\mathrm{ZrBn}(\beta)\right), 64.0$ (s, $\mathrm{CH}_{2}$ of $\mathrm{ZrBn}(\mathrm{T})), 62.6\left(\mathrm{~s}, \mathrm{CH}_{2}\right.$ of $\left.\mathrm{ZrBn}(\beta)\right), 36.1$ (s, $C$ of $\left.{ }^{t} \mathrm{Bu}^{2}(\beta)\right), 35.9$ (s, $C$ of ${ }^{t} \mathrm{Bu}^{2}(\mathrm{~T})$ ), $35.3\left(\mathrm{~s}, C\right.$ of $\left.{ }^{t} \mathrm{Bu}^{2}(\beta)\right), 34.8\left(\mathrm{~s}, C\right.$ of $\left.{ }^{t} \mathrm{Bu}^{4}(\beta)\right), 34.7$ (s, $C$ of $\left.{ }^{t} \mathrm{Bu}^{4}(\beta)\right), 34.6\left(\mathrm{~s}, C\right.$ of $\left.{ }^{t} \mathrm{Bu}^{4}(\mathrm{~T})\right), 31.5$ (s, $\mathrm{CH}_{3}$ of $\left.{ }^{t} \mathrm{Bu}^{4}(\mathrm{~T})\right), 31.4$ (two overlapping s, $\mathrm{CH}_{3}$ of ${ }^{\mathrm{t}} \mathrm{Bu}^{4}(\beta)$ ), 30.6 (two overlapping s, $\mathrm{CH}_{3}$ of ${ }^{t} \mathrm{Bu}^{2}(\mathrm{~T})$ and $\mathrm{CH}_{3}$ of $\left.{ }^{t} \mathrm{Bu}^{2}(\beta)\right), 28.7\left(\mathrm{~s}, \mathrm{CH}_{3}\right.$ of $\left.{ }^{t} \mathrm{Bu}^{2}(\beta)\right)$. Elemental Analysis: calculated for $\mathrm{C}_{72} \mathrm{H}_{78} \mathrm{~N}_{2} \mathrm{O}_{2} \mathrm{P}_{2} \mathrm{Zr}$ : C, 74.77; $\mathrm{H}, 6.80 ; \mathrm{N}$, 2.42. Found: $\mathrm{C}, 69.03 ; \mathrm{H}, 7.15 ; \mathrm{N}, 2.59$. A satisfactory elemental analysis could not be obtained ( $\mathrm{C}$ was always too low).

\section{Synthesis of complex $2 c$}

Ligand $\mathbf{1} \mathbf{c H}_{\mathbf{2}}$ (172mg, $\left.0.2 \mathrm{mmol}\right)$ was suspended in $\mathrm{Et}_{2} \mathrm{O}(10 \mathrm{ml})$ and tetrabenzylzirconium $(0.182 \mathrm{~g}, 0.4 \mathrm{mmol})$ were added then stirred at room temperature for $4 \mathrm{~h}$, during which a yellow precipitate appeared. The suspension was filtered, and the solid was washed with $\mathrm{Et}_{2} \mathrm{O}(2 \times 5 \mathrm{~mL})$ and dried under vacuum to give complex 2 c containing 1 eq of $\mathrm{Et}_{2} \mathrm{O}$ (195 mg, 59\%). ${ }^{31} \mathbf{P}\left\{{ }^{1} \mathbf{H}\right\}$ NMR (243MHz, $\left.\mathrm{CDCl}_{3}, 300 \mathrm{~K}\right)$ : $\delta=30.8\left(\mathrm{v}_{1 / 2}=7 \mathrm{~Hz}\right) .{ }^{1} \mathrm{H}$ NMR $(600 \mathrm{MHz}$, $\left.\mathrm{CDCl}_{3}, 300 \mathrm{~K}\right): \delta=7.71\left(\mathrm{~s}, 2 \mathrm{H}, \mathrm{H3}\right.$ of PAr), 7.35-7.29 (m, 4H, $\mathrm{PPh}_{2}$ ), 7.25-7.17 (m, 16H, $\left.\mathrm{PPh}_{2}\right), 6.95\left(\mathrm{brt},{ }^{3} \mathrm{JHH}_{\mathrm{HH}}=7.5 \mathrm{~Hz}, 12 \mathrm{H}, m\right.$ of $\mathrm{ZrBn}), 6.76\left(\mathrm{brd},{ }^{3} \mathrm{H}_{\mathrm{HH}}=7.5 \mathrm{~Hz}, 12 \mathrm{H}, \mathrm{o}\right.$ of $\left.\mathrm{ZrBn}\right), 6.72\left(\mathrm{bd},{ }^{3} \mathrm{JPH}_{\mathrm{PH}}=13.1\right.$ $\mathrm{Hz}, 2 \mathrm{H}, \mathrm{H} 5$ of PAr), $6.58\left(\mathrm{t}, 3 \mathrm{~J}_{\mathrm{HH}}=7.5 \mathrm{~Hz}, 6 \mathrm{H}, p\right.$ of $\mathrm{ZrBn}$ ), $2.25(\mathrm{dt}$, $\left.3 J_{\mathrm{PH}}=25.5,3 J_{\mathrm{HH}}=8.1,4 \mathrm{H}, \mathrm{NCH}_{2}\right), 1.83\left(\mathrm{~s}, 12 \mathrm{H}, \mathrm{CH}_{2}\right.$ of $\left.\mathrm{ZrBn}\right) 1.51$ $\left(\mathrm{s}, 18 \mathrm{H},{ }^{t} \mathrm{Bu}^{2}\right), 1.35$ (bs, $\left.2 \mathrm{H}, \mathrm{NCH}_{2} \mathrm{CH}_{2}\right), 1.22\left(\mathrm{~s}, 18 \mathrm{H},{ }^{t} \mathrm{Bu}^{4}\right) .{ }^{13} \mathrm{C}\left\{{ }^{1} \mathrm{H}\right\}$ NMR (150.9 MHz, $\mathrm{CDCl}_{3}, 300 \mathrm{~K}$ ): $\delta=165.4$ (s, C1 of PAr), 148.4 (s, Ci of ZrBn), 140.3 (d, ${ }^{3} J_{\mathrm{CP}}=12.2 \mathrm{~Hz}, C 4$ of PAr), $139.5\left(\mathrm{~d},{ }^{3} J_{\mathrm{CP}}=\right.$ $5.9 \mathrm{~Hz}, C 2$ of PAr), 133.7 (s, $p$ of $\mathrm{PPh}_{2}$ ), 133.4 (d, $J_{\mathrm{CP}}=9.8 \mathrm{~Hz}, o / m$ of $P_{P h}$ ), 130.7 (s, C3 of PAr), $129.6\left(\mathrm{~d}, J_{\mathrm{CP}}=12.1 \mathrm{~Hz}, \mathrm{~m} / \mathrm{o}\right.$ of $\mathrm{PPh}_{2}$ ), $129.0\left(\mathrm{~d},{ }^{2} \mathrm{~J}_{\mathrm{CP}}=10.8 \mathrm{~Hz}, \mathrm{C5}\right.$ of PAr), 128.3 (s, $m$ of ZrBn), 126.6 (s, $o$ of $\mathrm{ZrBn}$ ), $125.2\left(\mathrm{~d},{ }^{1} J_{\mathrm{CP}}=103.1 \mathrm{~Hz}, \mathrm{Ci}\right.$ of $\mathrm{PPh}_{2}$ ), 120.6 (s, $p$ of $\mathrm{ZrBn}$ ), 109.4 (d, ${ }^{1} J_{\mathrm{CP}}=100.1 \mathrm{~Hz}, \mathrm{C} 6$ of PAr), 72.3 (s, $\mathrm{CH}_{2}$ of $\mathrm{ZrBn}$ ), $40.8\left(\mathrm{~d},{ }^{3} \mathrm{~J}_{\mathrm{CP}}=4.3 \mathrm{~Hz}, \mathrm{NCH}_{2}\right), 35.4\left(\mathrm{~s}, \mathrm{C}\right.$ of $\left.t \mathrm{Bu}^{2}\right), 34.4\left(\mathrm{~s}, \mathrm{C}\right.$ of $\left.t \mathrm{Bu}^{4}\right)$, 33.7 (s, $\mathrm{NCH}_{2}-\mathrm{CH}_{2}$ ), 31.5 (s, $\mathrm{CH}_{3}$ of $\left.t \mathrm{Bu}^{4}\right), 30.5$ (s, $\mathrm{CH}_{3}$ of $\left.t \mathrm{Bu}^{2}\right)$. Elemental Analysis: calculated for $\mathrm{C}_{97} \mathrm{H}_{108} \mathrm{~N}_{2} \mathrm{O}_{2} \mathrm{P}_{2} \mathrm{Zr}_{2}: \mathrm{C}, 73.82 ; \mathrm{H}$, 6.90; N, 1.77. Found: $C, 71.09 ; \mathrm{H}, 7.19 ; \mathrm{N}, 1.89$. A satisfactory elemental analysis could not be obtained ( $C$ was always too low).

\section{Synthesis of complex $3 a$}

Complex 2a (340 mg, $0.3 \mathrm{mmol}$ ) and ${ }^{~} \mathrm{PrOH}$ (180 mg, $3.0 \mathrm{mmol}$ ) were mixed in $6 \mathrm{~mL}$ of $\mathrm{CH}_{2} \mathrm{Cl}_{2}$. The reaction mixture was stirred for $20 \mathrm{~min}$, during which it turned gradually colourless. The volatiles were removed under vacuum, and the solid residue was triturated with pentane, then dried under vacuum, yielding $3 a$ as a white solid ( $88 \mathrm{mg}, 28 \%$ ). The low yield is due to the solubility of $\mathbf{3 a}$ in pentane. Alternatively, 3a may be synthesized via the reaction of ligand $\mathbf{1 a H}_{2}$ with $\left[\mathrm{Zr}\left(\mathrm{NMe}_{2}\right)_{4}\right]$ followed by alcoholysis with ${ }^{i} \mathrm{PrOH} .{ }^{31} \mathrm{P}\left\{{ }^{1} \mathrm{H}\right\}$ NMR (243 MHz, $\left.\mathrm{CD}_{2} \mathrm{Cl}_{2}, 250 \mathrm{~K}\right)$ : $\delta=32.7\left(\mathrm{~s}, \mathrm{v}_{1 / 2} \approx 5 \mathrm{~Hz}, \mathrm{P}(\mathrm{T})\right), 31.6\left(\mathrm{~s}, \mathrm{v}_{1 / 2} \approx 5 \mathrm{~Hz}, \mathrm{P}(\beta)\right), 29.6(\mathrm{~s}$, $\left.\mathrm{v}_{1 / 2} \approx 5 \mathrm{~Hz}, \mathrm{P}(\beta)\right) .{ }^{1} \mathrm{H}$ NMR (600 MHz, $\left.\mathrm{CD}_{2} \mathrm{Cl}_{2}, 250 \mathrm{~K}\right): \delta=7.98(\mathrm{~m}$, $2 \mathrm{H}, \mathrm{o}$ of $\left.\mathrm{PPh}_{2}(\beta)\right), 7.88\left(\mathrm{~m}, 2 \mathrm{H}, \mathrm{o}\right.$ of $\left.\mathrm{PPh}_{2}(\beta)\right), 7.66-7.58(\mathrm{~m}, \mathrm{CH}-$ $\mathrm{Ar})$, 7.58-7.32 (m, CH-Ar), $7.22\left(\mathrm{~m}, 2 \mathrm{H}, \mathrm{o}\right.$ of $\left.\mathrm{PPh}_{2}(\beta)\right), 6.78(\mathrm{dd}$, ${ }^{3} J_{\mathrm{PH}}=16.0 \mathrm{~Hz}, 1 \mathrm{H},{ }^{4} J_{\mathrm{HH}}=2.2 \mathrm{~Hz}, \mathrm{H} 5$ of $\left.\operatorname{PAr}(\beta)\right), 6.69\left(\mathrm{dd},{ }^{3} J_{\mathrm{PH}}=\right.$ $13.3 \mathrm{~Hz},{ }^{4} J_{\mathrm{HH}}=2.2 \mathrm{~Hz}, 1 \mathrm{H}, \mathrm{H} 5$ of $\left.\operatorname{PAr}(\beta)\right), 6.46\left(\mathrm{dd},{ }^{3} \mathrm{~J}_{\mathrm{PH}}=15.6 \mathrm{~Hz}\right.$, $1 \mathrm{H},{ }^{4} \mathrm{~J}_{\mathrm{HH}}=2.2 \mathrm{~Hz}, \mathrm{H} 5$ of $\left.\operatorname{PAr}(\mathrm{T})\right), 4.60$ (hept, ${ }^{3} \mathrm{~J}_{\mathrm{HH}}=6.0 \mathrm{~Hz}, \mathrm{CH}$ of $\left.{ }^{i} \operatorname{Pr}(\beta)\right), 3.90\left(\mathrm{~m}, 1 \mathrm{H}, \mathrm{CH}_{2} \mathrm{~N}(\beta)\right), 3.70\left(\right.$ hept, ${ }^{3} \mathrm{~J}_{\mathrm{HH}}=6.0 \mathrm{~Hz}, 1 \mathrm{H}, \mathrm{CH}$ of $\left.{ }^{i} \operatorname{Pr}(\mathrm{T})\right), 3.23\left(\right.$ hept $^{3}{ }^{3} \mathrm{HH}=6.0 \mathrm{~Hz}, 1 \mathrm{H}, \mathrm{CH}$ of $\left.{ }^{i} \operatorname{Pr}(\beta)\right), 3.13(\mathrm{~m}, 4 \mathrm{H}$, $\left.\mathrm{CH}_{2} \mathrm{~N}(\mathrm{~T})\right), 2.80\left(\mathrm{~m}, 1 \mathrm{H}, \mathrm{CH}_{2} \mathrm{~N}(\beta)\right), 2.68\left(\mathrm{~m}, 1 \mathrm{H}, \mathrm{CH}_{2} \mathrm{~N}(\beta)\right), 2.55(\mathrm{~m}$, $\left.1 \mathrm{H}, \mathrm{CH}_{2} \mathrm{~N}(\beta)\right), 1.47\left(\mathrm{~s}, 9 \mathrm{H}, \mathrm{CH}_{3}\right.$ of $\left.{ }^{t} \mathrm{Bu}^{2}(\beta)\right), 1.45\left(\mathrm{~s}, 18 \mathrm{H}, \mathrm{CH}_{3}\right.$ of $\left.{ }^{t} \mathrm{Bu}^{2}(\mathrm{~T})\right), 1.22\left(\mathrm{~d},{ }^{3} \mathrm{~J}_{\mathrm{HH}}=6.0 \mathrm{~Hz}, 3 \mathrm{H}, \mathrm{CH}_{3}\right.$ of $\left.\operatorname{Pr}(\beta)\right), 1.17\left(\mathrm{~s}, 9 \mathrm{H}, \mathrm{CH}_{3}\right.$ of ${ }^{t} \mathrm{Bu}^{2}(\beta)$ overlapping with $\mathrm{CH}_{3}$ of $\left.{ }^{i} \operatorname{Pr}(\beta)\right), 1.16\left(d,{ }^{3}{ }_{\mathrm{HH}}=6.0 \mathrm{~Hz}\right.$, $3 \mathrm{H}, \mathrm{CH}_{3}$ of ${ }^{i} \operatorname{Pr}(\beta)$ overlapping with $\mathrm{CH}_{3}$ of $\left.{ }^{t} \mathrm{Bu}^{2}(\beta)\right), 1.13(\mathrm{~s}, 9 \mathrm{H}$, $\mathrm{CH}_{3}$ of $\left.{ }^{t} \mathrm{Bu}^{4}(\beta)\right), 1.08\left(\mathrm{~s}, 9 \mathrm{H}, \mathrm{CH}_{3}\right.$ of $\left.{ }^{t} \mathrm{Bu}^{4}(\beta)\right), 1.04\left(\mathrm{~s}, 18 \mathrm{H}, \mathrm{CH}_{3}\right.$ of $\left.{ }^{t} \mathrm{Bu}^{4}(\mathrm{~T})\right), 0.64\left(\mathrm{~d},{ }^{3} \mathrm{~J}_{\mathrm{HH}}=6.0 \mathrm{~Hz}, 3 \mathrm{H}, \mathrm{CH}_{3}\right.$ of $\left.{ }^{i} \operatorname{Pr}(\beta)\right), 0.54\left(\mathrm{~d},{ }^{3} J_{\mathrm{HH}}=\right.$ $6.0 \mathrm{~Hz}, 3 \mathrm{H}, \mathrm{CH}_{3}$ of $\left.{ }^{i} \operatorname{Pr}(\beta)\right), 0.51\left(\mathrm{~d},{ }^{3} \mathrm{~J}_{\mathrm{HH}}=6.0 \mathrm{~Hz}, 12 \mathrm{H}, \mathrm{CH}_{3}\right.$ of $\left.{ }^{i} \operatorname{Pr}(\mathrm{T})\right) .{ }^{13} \mathrm{C}\left\{{ }^{1} \mathrm{H}\right\}$ NMR (151 MHz, $\left.\mathrm{CD}_{2} \mathrm{Cl}_{2}, 250 \mathrm{~K}\right): \delta=168.3\left(\mathrm{~d},{ }^{2} J_{\mathrm{PC}}\right.$ $=4.1 \mathrm{~Hz}, C 1$ of $\operatorname{PAr}(\beta)), 167.3\left(\mathrm{~d},{ }^{2} J_{\mathrm{PC}}=1.9 \mathrm{~Hz}, C 1\right.$ of $\left.\operatorname{PAr}(\mathrm{T})\right), 164.5$ $\left(d,{ }^{2} J_{P C}=2.2 \mathrm{~Hz}, C 1\right.$ of $\left.\operatorname{PAr}(\beta)\right), 139.3\left(d, 3 J_{P C}=6.9 \mathrm{~Hz}, C 2\right.$ of $\operatorname{PAr}(\beta)), 139.0\left(\mathrm{~d},{ }^{3} \mathrm{JC}_{\mathrm{PC}}=7.6 \mathrm{~Hz}, C 2\right.$ of $\left.\operatorname{PAr}(\beta)\right), 137.9\left(\mathrm{~d}, 3 \mathrm{~J}_{\mathrm{PC}}=7.6\right.$ $\mathrm{Hz}, \mathrm{C} 2$ of $\operatorname{PAr}(\mathrm{T})), 137.0\left(\mathrm{~d},{ }^{3} \mathrm{JPC}_{\mathrm{PC}}=14.3 \mathrm{~Hz}, \mathrm{C} 4\right.$ of $\left.\operatorname{PAr}(\beta)\right), 136.1(\mathrm{~d}$, ${ }^{3} J_{\mathrm{PC}}=14.9 \mathrm{~Hz}, C 4$ of $\left.\operatorname{PAr}(\mathrm{T})\right), 134.0\left(\mathrm{~d},{ }^{3} J_{\mathrm{PC}}=13.7 \mathrm{~Hz}, C 4\right.$ of $\operatorname{PAr}(\beta)$ overlapping with $O$ of $\left.\mathrm{PPh}_{2}(\beta)\right), 133.9\left(\mathrm{~d}, 2 J_{\mathrm{PC}}=9.0 \mathrm{~Hz}, O\right.$ of $\mathrm{PPh}_{2}(\beta)$ overlapping with $C 4$ of $\left.\operatorname{PAr}(\beta)\right), 133.6\left(\mathrm{~d},{ }^{2} J_{\mathrm{PC}}=9.2 \mathrm{~Hz}, 0\right.$ of $\mathrm{PPh}_{2}(\beta)$ overlapping with $O$ of $\left.\mathrm{PPh}_{2}(\beta)\right), 133.5\left(\mathrm{~d},{ }^{2} \mathrm{JPC}_{\mathrm{PC}}=10.2\right.$ $\mathrm{Hz}, O$ of $\mathrm{PPh}_{2}(\beta)$ overlapping with $o$ of $\left.\mathrm{PPh}_{2}(\beta)\right), 133.4\left(\mathrm{~d},{ }^{2} \mathrm{JPC}_{\mathrm{PC}}=\right.$ 9.5 Hz, o of $\left.\mathrm{PPh}_{2}(\mathrm{~T})\right), 133.1\left(\mathrm{~d},{ }^{2} J_{\mathrm{PC}}=9.2 \mathrm{~Hz}, o\right.$ of $\left.\mathrm{PPh}_{2}(\beta)\right), 132.1$ $\left(d,{ }^{4} J_{\mathrm{PC}}=2.4 \mathrm{~Hz}, p\right.$ of $\left.\mathrm{PPh}_{2}(\beta)\right), 132.0\left(\mathrm{~d},{ }^{4} J_{\mathrm{PC}}=1.7 \mathrm{~Hz}, p\right.$ of $\left.\mathrm{PPh}_{2}(\beta)\right), 131.8\left(\mathrm{~d},{ }^{4} \mathrm{JPC}_{\mathrm{PC}}=1.7 \mathrm{~Hz}, p\right.$ of $\mathrm{PPh}_{2}(\mathrm{~T})$ overlapping with $i$ of $\operatorname{PAr}(\beta)), 131.6\left(d,{ }^{1} J_{P C}=89.5 \mathrm{~Hz}, i\right.$ of $\operatorname{PAr}(\beta)$ overlapping with $p$ of $\mathrm{PPh}_{2}(\mathrm{~T})$ and $p$ of $\left.\mathrm{PPh}_{2}(\beta)\right), 131.5\left(\mathrm{~d},{ }^{4} \mathrm{~J}_{\mathrm{PC}}=2.2 \mathrm{~Hz}\right.$, two $p$ of $\mathrm{PPh}_{2}(\beta)$ overlapping with $i$ of $\left.\operatorname{PAr}(\beta)\right), 130.3\left(\mathrm{~d},{ }^{1} j_{\mathrm{PC}}=113.5 \mathrm{~Hz}, i\right.$ of $\operatorname{PAr}(\beta)$ overlapping with $i$ of $\operatorname{PAr}(\beta)), 130.0\left(d,{ }^{1} J_{P C}=88.1 \mathrm{~Hz}, i\right.$ of $\operatorname{PAr}(\beta)$ overlapping with $i$ of $\operatorname{PAr}(\beta)), 129.2\left(d,{ }^{1} J_{\mathrm{PC}}=90.9 \mathrm{~Hz}, i\right.$ of $\operatorname{PAr}(\mathrm{T})$ ), 128.6-128.3 (m, overlapping $\mathrm{CH}-\mathrm{Ar}), 128.3$ (s, $\mathrm{CH}-\mathrm{Ar}$ ), $128.0(\mathrm{~s}, C 3$ of $\operatorname{PAr}(\beta)), 127.6\left(\mathrm{~d},{ }^{2} \mathrm{JPC}_{\mathrm{PC}}=11.3 \mathrm{~Hz}, C 5\right.$ of $\left.\operatorname{PAr}(\beta)\right)$, $127.3\left(d,{ }^{2} J_{P C}=12.8 \mathrm{~Hz}, C 5\right.$ of $\operatorname{PAr}(\beta)$ overlapping with $i$ of $\operatorname{PAr}(\beta)), 127.1\left(\mathrm{~d},{ }^{1} J_{\mathrm{PC}}=87.9 \mathrm{~Hz}, i\right.$ of $\left.\operatorname{PAr}(\beta)\right), 126.4\left(\mathrm{~d},{ }^{2} J_{\mathrm{PC}}=14.2\right.$ $\mathrm{Hz}, C 5$ of $\operatorname{PAr}(\mathrm{T})), 112.1\left(\mathrm{~d},{ }^{1}{ }_{\mathrm{PC}}=122.0 \mathrm{~Hz}, \mathrm{C} 6\right.$ of $\left.\operatorname{PAr}(\mathrm{T})\right), 109.8$ $\left(d,{ }^{1} J_{P C}=102.1 \mathrm{~Hz}, C 6\right.$ of $\left.\operatorname{PAr}(\beta)\right), 108.7\left(d,{ }^{1} J_{P C}=117.4 \mathrm{~Hz}, C 6\right.$ of $\operatorname{PAr}(\beta)), 69.4\left(\mathrm{~s}, \mathrm{CH}\right.$ of $\left.{ }^{i} \operatorname{Pr}(\beta)\right), 69.2\left(\mathrm{~s}, \mathrm{CH}\right.$ of $\left.{ }^{i} \operatorname{Pr}(\beta)\right), 67.6$ (s, $\mathrm{CH}$ of $\left.{ }^{i} \operatorname{Pr}(\mathrm{T})\right), 52.9\left(\mathrm{~d},{ }^{2} J_{\mathrm{PC}}=3.3 \mathrm{~Hz}, \mathrm{CH}_{2} \mathrm{~N}(\beta)\right), 51.6\left(\mathrm{dd},{ }^{3} J_{\mathrm{PC}}=17.5 \mathrm{~Hz}\right.$, $\left.{ }^{2} J_{\mathrm{PC}}=3.9 \mathrm{~Hz}, \mathrm{CH}_{2} \mathrm{~N}(\mathrm{~T})\right), 50.1\left(\mathrm{dd},{ }^{3} \mathrm{JPC}_{\mathrm{PC}}=18.2 \mathrm{~Hz},{ }^{2} \mathrm{~J}_{\mathrm{PC}}=4.7 \mathrm{~Hz}\right.$, $\left.\mathrm{CH}_{2} \mathrm{~N}(\beta)\right), 35.7\left(\mathrm{~d},{ }^{4} J_{\mathrm{PC}}=1.4 \mathrm{~Hz}, C\right.$ of $\left.{ }^{t} \mathrm{Bu}^{2}(\beta)\right), 35.5(\mathrm{~m}, C$ of $\left.{ }^{t} \mathrm{Bu}^{2}(\mathrm{~T})\right), 35.3\left(\mathrm{~d},{ }^{4} J_{\mathrm{PC}}=1.5 \mathrm{~Hz}, C\right.$ of $\left.{ }^{t} \mathrm{Bu}^{2}(\beta)\right), 34.0\left(\mathrm{~s}, C\right.$ of $\left.{ }^{t} \mathrm{Bu}^{4}(\beta)\right)$, $33.9\left(\mathrm{~s}, C\right.$ of ${ }^{t} \mathrm{Bu}^{4}(\beta)$ overlapping with $C$ of $\left.{ }^{t} \mathrm{Bu}^{4}(\mathrm{~T})\right), 31.3\left(\mathrm{~s}, \mathrm{CH}_{3}\right.$ of $\left.{ }^{t} \mathrm{Bu}^{4}(\beta)\right), 31.2\left(\mathrm{~s}, \mathrm{CH}_{3}\right.$ of ${ }^{t} \mathrm{Bu}^{4}(\mathrm{~T})$ ), 31.1 (s, $\mathrm{CH}_{3}$ of $\left.{ }^{t} \mathrm{Bu}^{4}(\beta)\right), 29.7$ (s, $\mathrm{CH}_{3}$ of ${ }^{t} \mathrm{Bu}^{2}(\beta)$ overlapping with $\mathrm{CH}_{3}$ of $\left.{ }^{t} \mathrm{Bu}^{2}(\mathrm{~T})\right), 29.4\left(\mathrm{~s}, \mathrm{CH}_{3}\right.$ of $\left.{ }^{t} \mathrm{Bu}^{2}(\beta)\right), 27.5\left(\mathrm{~s}, \mathrm{CH}_{3}\right.$ of $\left.{ }^{i} \operatorname{Pr}(\beta)\right), 27.5\left(\mathrm{~s}, \mathrm{CH}_{3}\right.$ of $\left.{ }^{i} \operatorname{Pr}(\beta)\right), 26.9\left(\mathrm{~s}, \mathrm{CH}_{3}\right.$ of $\left.{ }^{i} \operatorname{Pr}(\mathrm{T})\right)$ ), $26.7\left(\mathrm{~s}, \mathrm{CH}_{3}\right.$ of $\left.{ }^{i} \operatorname{Pr}(\beta)\right), 26.7\left(\mathrm{~s}, \mathrm{CH}_{3}\right.$ of $\left.{ }^{i} \operatorname{Pr}(\beta)\right)$. Elemental Analysis: calculated for $\mathrm{C}_{60} \mathrm{H}_{78} \mathrm{~N}_{2} \mathrm{O}_{4} \mathrm{P} 2 \mathrm{Zr}: \mathrm{C}, 69.00 ; \mathrm{H}, 7.53 ; \mathrm{N}$, 2.68. Found: $\mathrm{C}, 67.32 ; \mathrm{H}, 7.31 ; \mathrm{N}, 2.62$.

\section{Synthesis of complex $3 b$}


Complex 2b (0.588 g, $0.5 \mathrm{mmol})$ was suspended in dichloromethane $(15 \mathrm{~mL})$ then isopropanol $(0.30 \mathrm{~g}, 5 \mathrm{mmol})$ was added and the solution was stirred for $3 \mathrm{hrs}$. The volatiles were removed under vacuum. The residue was suspended in pentane $(5 \mathrm{~mL})$, filtered and washed with pentane $(3 \times 5 \mathrm{~mL})$, yielding $\mathbf{3 b}$ as a white powder $(0.418 \mathrm{~g}, 77 \%) .{ }^{31} \mathbf{P}\left\{{ }^{1} \mathrm{H}\right\}$ NMR $\left(243 \mathbf{~ M H z}, \mathbf{d}_{\mathbf{8}^{-}}\right.$ THF, $250 \mathrm{~K}): \delta=26.8\left(\mathrm{~s}, \mathrm{v}_{1 / 2} \approx 3 \mathrm{~Hz}, \mathrm{P}(\beta)\right), 24.3\left(\mathrm{~s}, \mathrm{v}_{1 / 2} \approx 3 \mathrm{~Hz}\right.$, $\mathrm{P}(\mathrm{T})), 21.5\left(\mathrm{~s}, \mathrm{v}_{1 / 2} \approx 4 \mathrm{~Hz}, \mathrm{P}(\beta)\right)$. ${ }^{1} \mathrm{H}$ NMR $\left(600 \mathrm{MHz}, \mathbf{d}_{8}-\mathrm{THF}, 250\right.$ K): $\delta=8.01\left(\mathrm{~m}, 2 \mathrm{H}, \quad O\right.$ of $\left.\mathrm{PPh}_{2}(\beta)\right), 7.86-7.71(\mathrm{~m}, \mathrm{CH}-\mathrm{Ar}$ overlapping with $O$ of $\left.\mathrm{PPh}_{2}(\beta)\right), 7.82\left(\mathrm{~m}, 2 \mathrm{H}, 0\right.$ of $\mathrm{PPh}_{2}(\mathrm{~T})$ overlapping with $\mathrm{CH}-\mathrm{Ar}), 7.71-7.55(\mathrm{~m}, \mathrm{CH}-\mathrm{Ar}), 7.61(\mathrm{~m}, 2 \mathrm{H}, p$ of $\left.\mathrm{PPh}_{2}(\mathrm{~T})\right)$, 7.52-7.43 (m, CH-Ar overlapping with $p$ of $\left.\mathrm{PPh}_{2}(\beta)\right)$, $7.46\left(\mathrm{~m}, 2 \mathrm{H}, p\right.$ of $\mathrm{PPh}_{2}(\beta)$ overlapping with $\left.\mathrm{CH}-\mathrm{Ar}\right), 7.40(\mathrm{~m}, \mathrm{CH}-$ $\operatorname{Ar}), 7.35\left(\mathrm{~d},{ }^{4} J_{\mathrm{HH}}=1.8 \mathrm{~Hz}, 1 \mathrm{H}, \mathrm{H} 3\right.$ of $\operatorname{PAr}(\beta)$ overlapping with $\mathrm{CH}-$ Ar), 7.33-7.24 (m, CH-Ar overlapping with two $H 3$ of $\operatorname{PAr}(\beta)$ and $\mathrm{H} 3$ of $\operatorname{PAr}(\mathrm{T})), 7.32\left(\mathrm{~d},{ }^{4} \mathrm{~J}_{\mathrm{HH}}=2.1 \mathrm{~Hz}, 1 \mathrm{H}, \mathrm{H} 3\right.$ of $\operatorname{PAr}(\mathrm{T})$ overlapping with $\mathrm{CH}-\mathrm{Ar}), 7.30$ ( $\mathrm{m}, \mathrm{H} 3$ of $\mathrm{PAr}(\beta)$ overlapping with $\mathrm{CH}-\mathrm{Ar}), 7.03$ $\left(\mathrm{m}, 2 \mathrm{H}, \mathrm{o}\right.$ of $\left.\mathrm{PPh}_{2}(\beta)\right), 6.61\left(\mathrm{dd},{ }^{3} \mathrm{JHH}_{\mathrm{PH}}=16.2 \mathrm{~Hz}, 1 \mathrm{H},{ }^{4} J_{\mathrm{HH}}=1.9 \mathrm{~Hz}\right.$, $H 5$ of $\operatorname{PAr}(\beta)), 6.53\left(\mathrm{dd},{ }^{3} J_{\mathrm{PH}}=15.5 \mathrm{~Hz},{ }^{4} J_{\mathrm{HH}}=2.2 \mathrm{~Hz}, 1 \mathrm{H}, \mathrm{H} 5\right.$ of $\operatorname{PAr}(\beta)), 6.42\left(\mathrm{dd},{ }^{3} J_{\mathrm{PH}}=15.9 \mathrm{~Hz}, 1 \mathrm{H},{ }^{4} J_{\mathrm{HH}}=2.1 \mathrm{~Hz}, \mathrm{H} 5\right.$ of $\left.\operatorname{PAr}(\mathrm{T})\right)$, 7.61-6.03 (m, H2 / H3 of $\operatorname{NAr}(\beta / \mathrm{T}))$, 6.03-5.97 (m, H2 / H3 of $\operatorname{NAr}(\beta / \mathrm{T})), 4.19\left(\right.$ hept $^{3}{ }^{3} \mathrm{HH}=6.0 \mathrm{~Hz}, \mathrm{CH}$ of $\left.{ }^{i} \operatorname{Pr}(\beta)\right), 3.78$ (hept, ${ }^{3}{ }_{\mathrm{HH}}$ $=6.0 \mathrm{~Hz}, 1 \mathrm{H}, \mathrm{CH}$ of $\left.{ }^{i} \operatorname{Pr}(\mathrm{T})\right), 3.40$ (hept, ${ }^{3} \mathrm{~J}_{\mathrm{HH}}=6.0 \mathrm{~Hz}, 1 \mathrm{H}, \mathrm{CH}$ of $\left.{ }^{i} \operatorname{Pr}(\beta)\right), 1.36\left(\mathrm{~s}, 9 \mathrm{H}, \mathrm{CH}_{3}\right.$ of $\left.{ }^{t} \mathrm{Bu}^{2}(\beta)\right), 1.30\left(\mathrm{~s}, 18 \mathrm{H}, \mathrm{CH}_{3}\right.$ of $\left.{ }^{t} \mathrm{Bu}^{2}(\mathrm{~T})\right)$, $1.12\left(\mathrm{~s}, 9 \mathrm{H}, \mathrm{CH}_{3}\right.$ of $\left.{ }^{t} \mathrm{Bu}^{4}(\beta)\right), 1.07$ (s, 9H, $\mathrm{CH}_{3}$ of ${ }^{t} \mathrm{Bu}^{4}(\beta)$ overlapping with $\mathrm{CH}_{3}$ of $\left.{ }^{t} \mathrm{Bu}^{4}(\mathrm{~T})\right), 1.06\left(\mathrm{~s}, 18 \mathrm{H}, \mathrm{CH}_{3}\right.$ of ${ }^{t} \mathrm{Bu}^{4}(\mathrm{~T})$ overlapping with $\mathrm{CH}_{3}$ of $\left.{ }^{t} \mathrm{Bu}^{4}(\beta)\right), 1.02\left(\mathrm{~d},{ }^{3} \mathrm{~J}_{\mathrm{HH}}=6.0 \mathrm{~Hz}, 3 \mathrm{H}, \mathrm{CH}_{3}\right.$ of $\operatorname{Pr}(\beta)$ overlapping with $\mathrm{CH}_{3}$ of $\left.{ }^{t} \mathrm{Bu}^{2}(\beta)\right), 1.00\left(\mathrm{~s}, 9 \mathrm{H}, \mathrm{CH}_{3}\right.$ of ${ }^{t} \mathrm{Bu}^{2}(\beta)$ overlapping with $\mathrm{CH}_{3}$ of $\left.{ }^{i} \operatorname{Pr}(\beta)\right), 0.86\left(\mathrm{~d},{ }^{3} \mathrm{~J}_{\mathrm{HH}}=6.0 \mathrm{~Hz}, 3 \mathrm{H}\right.$, $\mathrm{CH}_{3}$ of $\left.{ }^{i} \operatorname{Pr}(\beta)\right), 0.79\left(\mathrm{~d},{ }^{3} \mathrm{~J}_{\mathrm{HH}}=6.0 \mathrm{~Hz}, 3 \mathrm{H}, \mathrm{CH}_{3}\right.$ of $\left.{ }^{i} \operatorname{Pr}(\beta)\right), 0.65(\mathrm{~d}$, ${ }^{3} J_{\mathrm{HH}}=6.0 \mathrm{~Hz}, 12 \mathrm{H}, \mathrm{CH}_{3}$ of $\left.{ }^{i} \operatorname{Pr}(\mathrm{T})\right), 0.49\left(\mathrm{~d},{ }^{3} \mathrm{~J}_{\mathrm{HH}}=6.0 \mathrm{~Hz}, 3 \mathrm{H}, \mathrm{CH}_{3}\right.$ of $\left.{ }^{i} \operatorname{Pr}(\beta)\right) .{ }^{13} \mathrm{C}\left\{{ }^{1} \mathbf{H}\right\}$ NMR (151 MHz, $\mathbf{d}_{8}$-THF, $\left.250 \mathrm{~K}\right): \delta=169.1(\mathrm{~d}$, ${ }^{2} J_{\mathrm{PC}}=2.9 \mathrm{~Hz}, C 1$ of $\left.\operatorname{PAr}(\beta)\right), 168.8\left(\mathrm{~d},{ }^{2} J_{\mathrm{PC}}=1.9 \mathrm{~Hz}, C 1\right.$ of $\left.\operatorname{PAr}(\mathrm{T})\right)$, $165.1\left(\mathrm{~d},{ }^{2} J_{\mathrm{PC}}=1.2 \mathrm{~Hz}, C 1\right.$ of $\left.\operatorname{PAr}(\beta)\right), 146.8\left(\mathrm{dd},{ }^{3} J_{\mathrm{PC}}=10.2 \mathrm{~Hz}\right.$, $2 J_{\mathrm{PC}}=2.2 \mathrm{~Hz}, C 1$ of $\left.\mathrm{NAr}(\beta)\right), 143.7\left(\mathrm{dd}, 3 J_{\mathrm{PC}}=18.5 \mathrm{~Hz},{ }^{2} J_{\mathrm{PC}}=2.4\right.$ $\mathrm{Hz}, \mathrm{C} 1$ of $\mathrm{NAr}(\mathrm{T})), 143.2$ (dd, ${ }^{3} \mathrm{JPC}_{\mathrm{PC}}=18.7 \mathrm{~Hz},{ }^{2} \mathrm{JPC}_{\mathrm{PC}}=5.2 \mathrm{~Hz}, \mathrm{C} 1$ of $\operatorname{NAr}(\beta)), 139.9\left(d,{ }^{3} J_{P C}=7.6 \mathrm{~Hz}, C 2\right.$ of $\left.\operatorname{PAr}(\beta)\right), 138.6\left(d,{ }^{3} J_{P C}=7.6\right.$ $\mathrm{Hz}, C 2$ of $\operatorname{PAr}(\beta)), 137.9\left(\mathrm{~d},{ }^{3} J_{\mathrm{PC}}=15.1 \mathrm{~Hz}, \mathrm{C} 2\right.$ of $\left.\operatorname{PAr}(\mathrm{T})\right), 137.7(\mathrm{~d}$, $3 J_{P C}=15.2 \mathrm{~Hz}, C 4$ of $\left.P A r(\beta)\right), 136.5\left(d, 3 J_{P C}=15.5 \mathrm{~Hz}, C 4\right.$ of $\left.\operatorname{PAr}(T)\right)$, $135.0\left(\mathrm{~d},{ }^{3} J_{\mathrm{PC}}=14.4 \mathrm{~Hz}, C 4\right.$ of $\left.\operatorname{PAr}(\beta)\right), 134.7\left(\mathrm{~d},{ }^{2} J_{\mathrm{PC}}=9.0 \mathrm{~Hz}\right.$, o of $\left.\mathrm{PPh}_{2}(\beta)\right), 134.4\left(\mathrm{~d},{ }^{2} \mathrm{JC}_{\mathrm{PC}}=10.2 \mathrm{~Hz}, \mathrm{o}\right.$ of $\mathrm{PPh}_{2}(\beta)$ overlapping with $o$ of $\left.\mathrm{PPh}_{2}(\beta)\right), 134.3\left(\mathrm{~d},{ }^{2} J_{\mathrm{PC}}=10.1 \mathrm{~Hz}, \mathrm{o}\right.$ of $\mathrm{PPh}_{2}(\beta)$ overlapping with $o$ of $\left.\mathrm{PPh}_{2}(\beta)\right), 134.2\left(\mathrm{~d},{ }^{2} \mathrm{JPC}_{\mathrm{PC}}=9.5 \mathrm{~Hz}\right.$, o of $\left.\mathrm{PPh}_{2}(\mathrm{~T})\right), 133.9(\mathrm{~d}$, ${ }^{2} J_{\mathrm{PC}}=9.4 \mathrm{~Hz}, o$ of $\left.\mathrm{PPh}_{2}(\beta)\right), 133.0\left(\mathrm{~m}, p\right.$ of $\left.\mathrm{PPh}_{2}(\beta)\right), 132.7(\mathrm{~m}, p$ of $\left.\mathrm{PPh}_{2}(\mathrm{~T})\right), 132.5\left(\mathrm{~m}\right.$, two overlapping $p$ of $\mathrm{PPh}_{2}(\beta)$ overlapping with $i$ of $\operatorname{PAr}(\beta)), 131.6\left(\mathrm{~d},{ }^{1} J_{\mathrm{PC}}=89.5 \mathrm{~Hz}\right.$, $i$ of $\operatorname{PAr}(\beta)$ overlapping with $p$ of $\mathrm{PPh}_{2}(\mathrm{~T})$ and $p$ of $\left.\mathrm{PPh}_{2}(\beta)\right), 132.1\left(\mathrm{~m}, p\right.$ of $\left.\mathrm{PPh}_{2}(\beta)\right), 131.2$ $\left(d,{ }^{1} J_{P C}=107.6 \mathrm{~Hz}, i\right.$ of $\left.\operatorname{PAr}(\beta)\right), 130.2\left(d,{ }^{1} J_{P C}=89.1 \mathrm{~Hz}, i\right.$ of $\operatorname{PAr}(\beta))$ ) 129.5-129.1 (m, overlapping $\mathrm{CH}$-Ar overlapping with $i$ of $\operatorname{PAr}(\beta)), 129.1\left(\mathrm{~d},{ }^{1} \mathrm{JPC}_{\mathrm{PC}}=88.2 \mathrm{~Hz}, i\right.$ of $\operatorname{PAr}(\beta)$ overlapping with $\mathrm{CH}-$ $\mathrm{Ar}), 128.8-128.6(\mathrm{~m}, \mathrm{CH}-\mathrm{Ar}$ overlapping with $i$ of $\operatorname{PAr}(\beta)), 128.2$ $\left(d,{ }^{1} J_{\mathrm{PC}}=89.2 \mathrm{~Hz}, i\right.$ of $\operatorname{PAr}(\beta)$ overlapping with $C 5$ of $\operatorname{PAr}(\beta)$ and $i$ of $\operatorname{PAr}(\mathrm{T})), 128.1\left(\mathrm{~d},{ }^{2} \mathrm{~J}_{\mathrm{PC}}=13.9 \mathrm{~Hz}, \mathrm{C} 5\right.$ of $\operatorname{PAr}(\beta)$ overlapping with $i$ of $\operatorname{PAr}(\beta)$ and $i$ of $\operatorname{PAr}(T)), 127.8\left(d,{ }^{1} J_{\mathrm{PC}}=92.0 \mathrm{~Hz}, i\right.$ of $\operatorname{PAr}(\mathrm{T})$ overlapping with $C 5$ of $\operatorname{PAr}(\beta)$ and $i$ of $\operatorname{PAr}(\beta)), 126.9\left(\mathrm{~d}, 2 J_{\mathrm{PC}}=\right.$ $14.8 \mathrm{~Hz}, C 5$ of $\operatorname{PAr}(\mathrm{T})), 126.5\left(\mathrm{~d},{ }^{2} \mathrm{~J}_{\mathrm{PC}}=14.4 \mathrm{~Hz}, C 5\right.$ of $\left.\operatorname{PAr}(\beta)\right)$, $124.5\left(d, 3 J_{P C}=5.1 \mathrm{~Hz}, C 2\right.$ of $\left.\operatorname{NAr}(\beta)\right), 121.2(\mathrm{~s}, C 3$ of $\operatorname{NAr}(\beta))$,
120.1-119.9 (m, overlapping $C 2$ of $\operatorname{NAr}(\beta)$ and $\operatorname{NAr}(T)), 118.7(\mathrm{~s}$, C3 of $\operatorname{NAr}(T)$ ), 118.2 (s, C3 of $\operatorname{NAr}(\beta)), 117.2\left(\mathrm{~d},{ }^{1} J_{P C}=123.6 \mathrm{~Hz}\right.$, C6 of $\operatorname{PAr}(T)), 115.4\left(d,{ }^{1} J_{P C}=124.0 \mathrm{~Hz}, C 6\right.$ of $\left.\operatorname{PAr}(\beta)\right), 109.4(d$, ${ }^{1} J_{\mathrm{PC}}=110.6 \mathrm{~Hz}, \mathrm{C} 6$ of $\left.\operatorname{PAr}(\beta)\right), 70.2\left(\mathrm{~s}, \mathrm{CH}\right.$ of $\left.{ }^{i} \operatorname{Pr}(\beta)\right), 69.9(\mathrm{~s}, \mathrm{CH}$ of $\left.{ }^{i} \operatorname{Pr}(\beta)\right), 68.9\left(\mathrm{~s}, \mathrm{CH}\right.$ of $\left.{ }^{i} \operatorname{Pr}(\mathrm{T})\right), 36.0\left(\mathrm{~d},{ }^{4} J_{\mathrm{PC}}=1.1 \mathrm{~Hz}, C\right.$ of $\left.{ }^{t} \mathrm{Bu}^{2}(\beta)\right)$, $35.7\left(d,{ }^{4} J_{\mathrm{PC}}=1.7 \mathrm{~Hz}, C\right.$ of $\left.{ }^{t} \mathrm{Bu}^{2}(\mathrm{~T})\right), 35.5\left(\mathrm{~d},{ }^{4} \mathrm{~J}_{\mathrm{PC}}=1.5 \mathrm{~Hz}, C\right.$ of $\left.{ }^{t} \mathrm{Bu}^{2}(\beta)\right), 34.5\left(\mathrm{~s}, C\right.$ of $\left.{ }^{t} \mathrm{Bu}^{4}(\beta)\right), 34.4\left(\mathrm{~s}, C\right.$ of ${ }^{t} \mathrm{Bu}^{4}(\mathrm{~T})$ ), 34.3 (s, $C$ of $\left.{ }^{t} \mathrm{Bu}^{4}(\beta)\right), 31.6\left(\mathrm{~m}\right.$, two $\mathrm{CH}_{3}$ of ${ }^{t} \mathrm{Bu}^{4}(\beta)$ overlapping with $\mathrm{CH}_{3}$ of $\left.{ }^{t} \mathrm{Bu}^{4}(\mathrm{~T})\right)$ ), $30.4\left(\mathrm{~s}, \mathrm{CH}_{3}\right.$ of $\left.{ }^{t} \mathrm{Bu}^{4}(\mathrm{~T})\right), 30.2\left(\mathrm{~s}, \mathrm{CH}_{3}\right.$ of $\left.{ }^{t} \mathrm{Bu}^{2}(\beta)\right), 30.0$ (s, $\mathrm{CH}_{3}$ of $\left.{ }^{\mathrm{t}} \mathrm{Bu}^{2}(\beta)\right), 27.5$ (s, $\mathrm{CH}_{3}$ of ${ }^{i} \operatorname{Pr}(\beta)$ overlapping with $\mathrm{CH}_{3}$ of $\left.{ }^{i} \operatorname{Pr}(\mathrm{T})\right), 27.4\left(\mathrm{~s}, \mathrm{CH}_{3}\right.$ of $\left.{ }^{i} \operatorname{Pr}(\beta)\right), 27.3\left(\mathrm{~s}, \mathrm{CH}_{3}\right.$ of $\left.{ }^{i} \operatorname{Pr}(\beta)\right), 27.1\left(\mathrm{~s}, \mathrm{CH}_{3}\right.$ of $\operatorname{Pr}(\beta)$ ). Elemental Analysis: calculated for $\mathrm{C}_{64} \mathrm{H}_{78} \mathrm{~N}_{2} \mathrm{O}_{4} \mathrm{P} 2 \mathrm{Zr}$ : C, 70.36; $H, 7.20 ; N, 2.56$. Found: $C, 69.03 ; H, 7.15 ; N, 2.59$.

\section{Synthesis of complex $4 a$}

Complex 2a $\quad\left(\begin{array}{llll}1.00 & \mathrm{~g} & 0.87 & \mathrm{mmol}\end{array}\right)$ and tris(pentafluorophenyl)borane $(0.447 \mathrm{~g}, 0.87 \mathrm{mmol})$ were dissolved in dichloromethane $(20 \mathrm{~mL})$ and stirred for $10 \mathrm{~min}$. The volatiles were removed under vacuum to obtain a foamy solid, which was triturated in pentane $(5 \mathrm{~mL})$ to give a lightbrown oil. The supernatant solution was removed and the oil was washed with pentane $(5 \times 5 \mathrm{~mL})$, and then dried under vacuum to give $6 \mathbf{a}$ as a beige powder containing $66 \mathrm{~mol} \%$ of pentane $(1.181 \mathrm{~g}, 78 \%)$. The ${ }^{1} \mathrm{H},{ }^{13} \mathrm{C}$ and ${ }^{31} \mathrm{P}$ NMR characterization was performed on a batch prepared by direct evaporation of a dichloromethane solution, hence the presence of 19 mol\% of dichloromethane. ${ }^{31} \mathrm{P}\left\{{ }^{1} \mathrm{H}\right\} \mathrm{NMR}\left(\mathbf{1 2 2} \mathbf{M H z}, \mathrm{CD}_{\mathbf{2}} \mathrm{Cl}_{2}\right.$, $300 \mathrm{~K}): \delta=38.2\left(\mathrm{v}_{1 / 2} \approx 5 \mathrm{~Hz}\right) .{ }^{1} \mathrm{H}$ NMR (600 MHz, $\left.\mathrm{CD}_{2} \mathrm{Cl}_{2}, 300 \mathrm{~K}\right)$ : $\delta=7.73\left(\mathrm{~m}, 2 \mathrm{H}, p\right.$ of $\mathrm{PPh}_{2}$ overlapping with $\mathrm{H} 3$ of $\left.\mathrm{PAr}\right), 7.71(\mathrm{~d}$, ${ }^{4} J_{\mathrm{HH}}=2.4 \mathrm{~Hz}, 2 \mathrm{H}, \mathrm{H} 3$ of PAr overlapping with $p$ of $\left.\mathrm{PPh}_{2}\right), 7.69(\mathrm{~m}$, $2 \mathrm{H}, p$ of $\left.\mathrm{PPh}_{2}\right), 7.59\left(\mathrm{~m}, 4 \mathrm{H}, m\right.$ of $\left.\mathrm{PPh}_{2}\right), 7.53\left(\mathrm{~m}, 4 \mathrm{H}, m\right.$ of $\left.\mathrm{PPh}_{2}\right)$, $7.38\left(\mathrm{~m}, 4 \mathrm{H}, o\right.$ of $\left.\mathrm{PPh}_{2}\right), 7.26\left(\mathrm{~m}, 4 \mathrm{H}, o\right.$ of $\left.\mathrm{PPh}_{2}\right), 6.85(\mathrm{~m}, 2 \mathrm{H}, m$ of $\mathrm{BBn}$ overlapping with $m$ of $\mathrm{ZrBn}), 6.83(\mathrm{~m}, 2 \mathrm{H}, m$ of $\mathrm{ZrBn}$ overlapping with $m$ of $B B n), 6.79(m, 1 \mathrm{H}, p$ of $\mathrm{ZrBn}$ overlapping with $p$ of $B B n), 6.76(m, 1 \mathrm{H}, p$ of BBn overlapping with $p$ of $\mathrm{ZrBn})$, $6.72(\mathrm{~m}, 2 \mathrm{H}, \mathrm{o}$ of $\mathrm{BBn}), 6.58\left(\mathrm{dd},{ }^{3} \mathrm{JPH}_{\mathrm{PH}}=15.9 \mathrm{~Hz},{ }^{4} J_{\mathrm{HH}}=2.4 \mathrm{~Hz}, 2 \mathrm{H}\right.$, H5 of PAr), $6.23(\mathrm{~m}, 2 \mathrm{H}, \mathrm{o}$ of $\mathrm{ZrBn}), 3.43\left(\mathrm{~m}, 2 \mathrm{H}, \mathrm{CH}_{2} \mathrm{~N}\right), 3.34(\mathrm{~m}$, $2 \mathrm{H}, \mathrm{CH}_{2} \mathrm{~N}$ ), 2.79 (bs, $2 \mathrm{H}, \mathrm{CH}_{2}$ of $\left.\mathrm{BBn}\right), 2.03\left(\mathrm{~s}, 2 \mathrm{H}, \mathrm{CH}_{2}\right.$ of $\mathrm{ZrBn}$ ), $1.58\left(\mathrm{~s}, 18 \mathrm{H}, \mathrm{CH}_{3}\right.$ of $\left.{ }^{t} \mathrm{Bu}^{2}\right), 1.11\left(\mathrm{~s}, 18 \mathrm{H}, \mathrm{CH}_{3}\right.$ of $\left.{ }^{t} \mathrm{Bu}^{4}\right) .{ }^{13} \mathrm{C}\left\{{ }^{1} \mathrm{H}\right\}$ NMR (151 MHz, $\mathrm{CD}_{2} \mathrm{Cl}_{2}, 300 \mathrm{~K}$ ): $\delta=161.4$ (s, C1 of PAr), 149.2 (s, $i$ of $\mathrm{BBn}), 148.6\left(\mathrm{dm},{ }^{1} J_{\mathrm{CF}}=236 \mathrm{~Hz}, \mathrm{CF}\right.$ of $\left.\mathrm{C}_{6} \mathrm{~F}_{5}\right), 145.0(\mathrm{~s}, i$ of $\mathrm{ZrBn})$, $144.0\left(\mathrm{~d},{ }^{3} \mathrm{~J}_{\mathrm{CP}}=15.0 \mathrm{~Hz}, \mathrm{C} 4\right.$ of PAr), $139.1\left(\mathrm{~d},{ }^{3} \mathrm{~J}_{\mathrm{CP}}=7.0 \mathrm{~Hz}, \mathrm{C} 2\right.$ of $\mathrm{PAr}), 138.0\left(\mathrm{dm},{ }^{1} J_{\mathrm{CF}}=241 \mathrm{~Hz}, C F\right.$ of $\left.\mathrm{C}_{6} \mathrm{~F}_{5}\right), 136.7\left(\mathrm{dm},{ }^{1} J_{\mathrm{CF}}=255\right.$ $\mathrm{Hz}, \mathrm{CF}$ of $\left.\mathrm{C}_{6} \mathrm{~F}_{5}\right), 134.4\left(\mathrm{~d},{ }^{4} \mathrm{~J}_{\mathrm{CP}}=2.4 \mathrm{~Hz}, p\right.$ of $\left.\mathrm{PPh}_{2}\right), 134.3\left(\mathrm{~d},{ }^{4} J_{\mathrm{CP}}=\right.$ $2.5 \mathrm{~Hz}, p$ of $\left.\mathrm{PPh}_{2}\right), 133.4\left(\mathrm{~d},{ }^{2} J_{\mathrm{CP}}=10.4 \mathrm{~Hz}, o\right.$ of $\left.\mathrm{PPh}_{2}\right), 133.2(\mathrm{~d}$, ${ }^{2} J_{\mathrm{CP}}=10.3 \mathrm{~Hz}$, o of $\left.\mathrm{PPh}_{2}\right), 131.4\left(\mathrm{~m}, \mathrm{C} 3\right.$ of PAr), $130.1\left(\mathrm{~d},{ }^{3} \mathrm{~J}_{\mathrm{CP}}=\right.$ $2.7 \mathrm{~Hz}, m$ of $\left.\mathrm{PPh}_{2}\right), 130.0\left(\mathrm{~d},{ }^{3} \mathrm{~J}_{\mathrm{CP}}=2.4 \mathrm{~Hz}, m\right.$ of $\left.\mathrm{PPh}_{2}\right), 129.1(\mathrm{~s}, m$ of $\mathrm{ZrBn}$ ), 128.9 (s, o of BBn), $128.2\left(\mathrm{~d},{ }^{2} J_{\mathrm{CP}}=13.8 \mathrm{~Hz}, \mathrm{C5}\right.$ of $\mathrm{PAr}$ ), 127.1 ( $s, m$ of $B B n), 126.2(m, o$ of $\mathrm{ZrBn}), 125.6$ (m, two overlapping $i$ of $\mathrm{PPh}_{2}$ ), 122.6 (s, $p$ of $\mathrm{BBn}$ ), 122.4 (s, $p$ of $\mathrm{ZrBn}$ ), $111.9\left(\mathrm{~d},{ }^{1} \mathrm{~J}_{\mathrm{CP}}=115.8 \mathrm{~Hz}, \mathrm{C6}\right.$ of PAr), $67.6\left(\mathrm{~s}, \mathrm{CH}_{2}\right.$ of $\left.\mathrm{ZrBn}\right), 52.1$ (dd, $\left.{ }^{3} J_{\mathrm{CP}}=15.4 \mathrm{~Hz},{ }^{2} \mathrm{~J}_{\mathrm{CP}}=4.1 \mathrm{~Hz}, \mathrm{CH}_{2} \mathrm{~N}\right), 36.2\left(\mathrm{~s}, \mathrm{C}\right.$ of $\left.{ }^{t} \mathrm{Bu}^{2}\right), 34.8$ (s, $\mathrm{C}$ of ${ }^{\mathrm{t}} \mathrm{Bu}^{4}$ ), 31.9 (n.o., $\mathrm{CH}_{2}$ of $\mathrm{BBn}$, visible in HSQC spectrum), $31.3\left(\mathrm{~s}, \mathrm{CH}_{3}\right.$ of $\left.{ }^{t} \mathrm{Bu}^{4}\right), 30.3\left(\mathrm{~s}, \mathrm{CH}_{3}\right.$ of $\left.{ }^{t} \mathrm{Bu}^{2}\right) .{ }^{19} \mathrm{~F}\left\{{ }^{1} \mathrm{H}\right\}$ NMR (282 MHz, $\left.\mathrm{CD}_{2} \mathrm{Cl}_{2}, 300 \mathrm{~K}\right): \delta=-131.4\left(\mathrm{~m}, o\right.$ of $\left.\mathrm{C}_{6} \mathrm{~F}_{5}\right),-164.8\left(\mathrm{t}, \mathrm{J}_{\mathrm{FF}}=20.6 \mathrm{~Hz}\right.$, $p$ of $\left.\mathrm{C}_{6} \mathrm{~F}_{5}\right),-167.7\left(\mathrm{~m}, m\right.$ of $\left.\mathrm{C}_{6} \mathrm{~F}_{5}\right) .{ }^{11} \mathrm{~B}\left\{{ }^{1} \mathrm{H}\right\}$ NMR $\left(96 \mathrm{MHz}, \mathrm{CD}_{2} \mathrm{Cl}_{2}\right.$, $300 \mathrm{~K}): \delta=-12.7$. Elemental Analysis: calculated for 
$\mathrm{C}_{86} \mathrm{H}_{78} \mathrm{BF}_{15} \mathrm{~N}_{2} \mathrm{O}_{2} \mathrm{P} 2 \mathrm{Zr}\left(\mathrm{C}_{5} \mathrm{H}_{12}\right)_{0.66}: \mathrm{C}, 64.30 ; \mathrm{H}, 5.19 ; \mathrm{N}, 1.68$. Found: C, 63.60; $\mathrm{H}, 4.94 ; \mathrm{N}, 1.75$.

\section{Synthesis of complex $4 \mathrm{~b}$}

Complex 2b $\quad(1.000 \quad \mathrm{~g}, \quad 0.75 \quad \mathrm{mmol})$ and tris(pentafluorophenyl)borane $(0.386 \mathrm{~g}, 0.75 \mathrm{mmol})$ were dissolved in toluene $(20 \mathrm{~mL})$ and stirred for $1 \mathrm{~h}$. The volatiles were removed under vacuum to give a foamy solid. The solid was suspended in pentane $(10 \mathrm{~mL})$, resulting in the formation of a brown oil, and the supernatant was removed. The oil was washed with pentane $(4 \times 5 \mathrm{~mL})$ then dried under vacuum to give $\mathbf{6 b}$ as a pale yellow powder containing $66 \mathrm{~mol} \%$ of toluene (1.148 g, 88\%). ${ }^{31} \mathbf{P}\left\{{ }^{1} \mathrm{H}\right\}$ NMR (202 MHz, $\left.\mathrm{CD}_{2} \mathrm{Cl}_{2}, 300 \mathrm{~K}\right): \delta=34.5$ $\left(v_{1 / 2} \approx 3 \mathrm{~Hz}\right) .{ }^{1} \mathrm{H}$ NMR $\left(500 \mathrm{MHz}, \mathrm{CD}_{2} \mathrm{Cl}_{2}, 300 \mathrm{~K}\right): \delta=7.83(\mathrm{~m}, 2 \mathrm{H}$, $p$ of $\left.\mathrm{PPh}_{2}\right), 7.70\left(\mathrm{~d},{ }^{4} J_{\mathrm{HH}}=2.0 \mathrm{~Hz}, 2 \mathrm{H}, \mathrm{H3}\right.$ of PAr overlapping with $m$ of $\left.\mathrm{PPh}_{2}\right), 7.69\left(\mathrm{~m}, 4 \mathrm{H}, \mathrm{m}\right.$ of $\mathrm{PPh}_{2}$ overlapping with $\mathrm{H3}$ of $\left.\mathrm{PAr}\right)$, 7.64-7.57 (m, $4 \mathrm{H}, o$ of $\mathrm{PPh}_{2}$ overlapping with $p$ of $\left.\mathrm{PPh}_{2}\right), 7.56(\mathrm{~m}$, $2 \mathrm{H}, p$ of $\left.\mathrm{PPh}_{2}\right), 7.37-7.30\left(\mathrm{~m}, 4 \mathrm{H}, o\right.$ of $\left.\mathrm{PPh}_{2}\right), 7.27(\mathrm{~m}, 4 \mathrm{H}, m$ of $\left.\mathrm{PPh}_{2}\right), 6.87(\mathrm{~m}, 2 \mathrm{H}, m$ of $\mathrm{BBn}), 6.81-6.66(\mathrm{~m}, 8 \mathrm{H}, p$ of $\mathrm{BBn}$ overlapping with $o$ of $\mathrm{BBn}, \mathrm{H5}$ of PAr, $m$ of $\mathrm{ZrBn}$ and $p$ of $\mathrm{ZrBn})$, $6.60(\mathrm{~m}, 2 \mathrm{H}$, o of $\mathrm{ZrBn}), 6.37$ (m, 2H, H3 of NAr), $6.07(\mathrm{~m}, 2 \mathrm{H}, \mathrm{H} 2$ of NAr), 2.84 (bs, $2 \mathrm{H}, \mathrm{CH}_{2}$ of BBn), 2.15 (s, 2H, $\mathrm{CH}_{2}$ of $\mathrm{ZrBn}$ ), 1.36 $\left(\mathrm{s}, 18 \mathrm{H}, \mathrm{CH}_{3}\right.$ of $\left.{ }^{t} \mathrm{Bu}^{2}\right), 1.19\left(\mathrm{~s}, 18 \mathrm{H}, \mathrm{CH}_{3}\right.$ of $\left.{ }^{t} \mathrm{Bu}^{4}\right) .{ }^{13} \mathrm{C}\left\{{ }^{1} \mathrm{H}\right\}$ NMR (126 $\mathrm{MHz}, \mathrm{CD}_{2} \mathrm{Cl}_{2}, 300 \mathrm{~K}$ ): $\delta=161.4$ (d, ${ }^{3} J_{\mathrm{PC}}=1.0 \mathrm{~Hz}, \mathrm{C} 1$ of $\mathrm{PAr}$ ), 149.1 (s, $i$ of $\mathrm{BBn}$ overlapping with $\mathrm{CF}$ of $\left.\mathrm{C}_{6} \mathrm{~F}_{5}\right), 148.6\left(\mathrm{dm},{ }^{1} J_{\mathrm{CF}}=241\right.$ $\mathrm{Hz}, \mathrm{CF}$ of $\mathrm{C}_{6} \mathrm{~F}_{5}$ overlapping with $i$ of $\left.\mathrm{BBn}\right), 144.1\left(\mathrm{~d},{ }^{3} J_{\mathrm{CP}}=14.5 \mathrm{~Hz}\right.$, C4 of PAr), 140.0 (dd, ${ }^{3} J_{C P}=13.6 \mathrm{~Hz},{ }^{2} J_{C P}=3.7 \mathrm{~Hz}, C 1$ of $\mathrm{NAr}$ ), $139.2\left(\mathrm{~d},{ }^{3} \mathrm{JP}_{\mathrm{CP}}=6.4 \mathrm{~Hz}, \mathrm{C} 2\right.$ of PAr), $138.0\left(\mathrm{dm},{ }^{1} J_{\mathrm{CF}}=243 \mathrm{~Hz}, \mathrm{CF}\right.$ of $\mathrm{C}_{6} \mathrm{~F}_{5}$ overlapping with $i$ of $\mathrm{ZrBn}$ and $C F$ of $\mathrm{C}_{6} \mathrm{~F}_{5}$ ), 137.0 (s, $i$ of $\mathrm{ZrBn}$ overlapping with two $C F$ of $\left.C_{6} F_{5}\right), 136.7\left(\mathrm{dm},{ }^{1} J_{\mathrm{CF}}=246 \mathrm{~Hz}, \mathrm{CF}\right.$ of $\mathrm{C}_{6} \mathrm{~F}_{5}$ overlapping with $\mathrm{CF}$ of $\mathrm{C}_{6} \mathrm{~F}_{5}$ and $i$ of $\left.\mathrm{ZrBn}\right), 135.1\left(\mathrm{~d},{ }^{4} \mathrm{~J}_{\mathrm{CP}}=\right.$ $2.7 \mathrm{~Hz}, p$ of $\left.\mathrm{PPh}_{2}\right), 134.4\left(\mathrm{~d},{ }^{4} J_{\mathrm{CP}}=2.8 \mathrm{~Hz}, p\right.$ of $\left.\mathrm{PPh}_{2}\right), 134.1\left(\mathrm{~d},{ }^{2} J_{C P}\right.$ $=10.7 \mathrm{~Hz}, o$ of $\left.\mathrm{PPh}_{2}\right), 133.1\left(\mathrm{~d},{ }^{2} J_{C P}=10.2 \mathrm{~Hz}, o\right.$ of $\left.\mathrm{PPh}_{2}\right), 131.8$ $\left(d,{ }^{4} J_{\mathrm{CP}}=1.8 \mathrm{~Hz}, \mathrm{C} 3\right.$ of $\left.\mathrm{PAr}\right), 130.2\left(\mathrm{~d},{ }^{3} \mathrm{~J}_{\mathrm{CP}}=13.1 \mathrm{~Hz}, m\right.$ of $\left.\mathrm{PPh}_{2}\right)$, $130.0\left(\mathrm{~d},{ }^{3} \mathrm{~J}_{\mathrm{CP}}=12.7 \mathrm{~Hz}, m\right.$ of $\left.\mathrm{PPh}_{2}\right), 129.6$ (s, $m$ of $\mathrm{ZrBn}$ ), 129.0 (s, $O$ of $B B n$ ), 128.8 (n.o., $i$ of $C_{6} F_{5}$ visible in $\mathrm{HMBC}$ spectrum), $128.5\left(\mathrm{~d},{ }^{2} \mathrm{JC}_{\mathrm{PC}}=15.0 \mathrm{~Hz}, \mathrm{C} 5\right.$ of PAr overlapping with toluene signal and $o$ of $\mathrm{ZrBn}$ ), 128.4 (s, o of ZrBn overlapping with $C 5$ of PAr), 127.1 (s, $m$ of $B B n$ ), $126.2\left(d,{ }^{1} J_{\mathrm{CP}}=96.5 \mathrm{~Hz}, i\right.$ of $\mathrm{PPh}_{2}$ overlapping with $i$ of $\left.\mathrm{PPh}_{2}\right), 125.4\left(\mathrm{~d},{ }^{1} J_{\mathrm{CP}}=89.1 \mathrm{~Hz}, i\right.$ of $\mathrm{PPh}_{2}$ overlapping with $i$ of $\mathrm{PPh}_{2}$ ), 125.0 (s, $p$ of $\mathrm{ZrBn}$ ), 122.6 (s, $p$ of $\mathrm{BBn}), 122.5\left(\mathrm{~d}, 3 \mathrm{~J}_{\mathrm{CP}}=5.6 \mathrm{~Hz}, \mathrm{C} 2\right.$ of NAr), 122.4 (s, C3 of NAr), $113.3\left(\mathrm{~d},{ }^{1} \mathrm{~J}_{C P}=114.7 \mathrm{~Hz} C 6\right.$ of PAr), $67.3\left(\mathrm{~s}, \mathrm{CH}_{2}\right.$ of $\left.\mathrm{ZrBn}\right), 35.9$ (s, $\mathrm{C}$ of ${ }^{t} \mathrm{Bu}^{2}$ ), 34.9 (s, $\mathrm{C}$ of ${ }^{t} \mathrm{Bu}^{4}$ ), 31.8 (n.o., $\mathrm{CH}_{2}$ of $\mathrm{BBn}$ visible in HSQC spectrum), $31.3\left(\mathrm{~s}, \mathrm{CH}_{3}\right.$ of $\left.{ }^{t} \mathrm{Bu}^{4}\right), 30.4\left(\mathrm{~s}, \mathrm{CH}_{3}\right.$ of $\left.{ }^{t} \mathrm{Bu}^{2}\right)$. ${ }^{19} \mathrm{~F}\left\{{ }^{1} \mathrm{H}\right\}$ NMR (470 MHz, $\left.\mathrm{CD}_{2} \mathrm{Cl}_{2}, 300 \mathrm{~K}\right): \delta=-131.3\left(\mathrm{~m}, \mathrm{o}\right.$ of $\left.\mathrm{C}_{6} \mathrm{~F}_{5}\right)$, $-165.0\left(\mathrm{t},{ }^{1} J_{\mathrm{CF}}=20.5 \mathrm{~Hz}, p\right.$ of $\left.\mathrm{C}_{6} \mathrm{~F}_{5}\right),-167.8\left(\mathrm{~m}, \mathrm{~m}\right.$ of $\left.\mathrm{C}_{6} \mathrm{~F}_{5}\right) .{ }^{11} \mathrm{~B}\left\{{ }^{1} \mathrm{H}\right\}$ NMR (160 MHz, $\left.\mathrm{CD}_{2} \mathrm{Cl}_{2}, 300 \mathrm{~K}\right): \delta=-12.7$. Elemental Analysis: calculated for $\mathrm{C}_{90} \mathrm{H}_{78} \mathrm{BF}_{15} \mathrm{~N}_{2} \mathrm{O}_{2} \mathrm{P}_{2} \mathrm{Zr}\left(\mathrm{C}_{5} \mathrm{H}_{8}\right)_{0.66}$ : $\mathrm{C}, 65.40 ; \mathrm{H}, 4.90 ; \mathrm{N}$, 1.63. Found: $C, 65.06 ; \mathrm{H}, 5.11 ; \mathrm{N}, 1.63$.

\section{Synthesis of complex $5 a$}

Complex 4a (0.339 g, $0.2 \mathrm{mmol}$ ) was dissolved in $6 \mathrm{~mL}$ of $\mathrm{CH}_{2} \mathrm{Cl}_{2}$ and a $0.2 \mathrm{M}$ solution of ${ }^{i} \mathrm{PrOH}$ in $\mathrm{CH}_{2} \mathrm{Cl}_{2}(500 \mu \mathrm{L})$ was added over $1 \mathrm{~min}$. The solution became progressively paler and some precipitate appeared. The suspension was filtered over diatomaceous earth in a pipette fitted with a borosilicate fiber filter. The clear solution was evaporated to dryness, and the residue was triturated in $5 \mathrm{~mL}$ of pentane. The supernatant solution was discarded and the residue was dried under vacuum, yielding complex $\mathbf{5 a}$ as a white powder containing $50 \mathrm{~mol} \%$ of pentane $(0.195 \mathrm{~g}, 86 \%) .{ }^{31} \mathrm{P}\left\{{ }^{1} \mathrm{H}\right\}$ NMR (243 MHz, $\left.\mathrm{CD}_{2} \mathrm{Cl}_{2}, 300 \mathrm{~K}\right): \delta=37.0\left(\mathrm{v}_{1 / 2} \approx 9 \mathrm{~Hz}\right) .{ }^{1} \mathrm{H}$ NMR $\left(600 \mathrm{MHz}, \mathrm{CD}_{2} \mathrm{Cl}_{2}\right.$, $300 \mathrm{~K}): \delta=7.72\left(\mathrm{~m}, 2 \mathrm{H}\right.$, two overlapping $p$ of $\left.\mathrm{PPh}_{2}\right), 7.69(\mathrm{~m}$, $2 \mathrm{H}, p$ of $\mathrm{PPh}_{2}$ overlapping with $p$ of $\left.\mathrm{PPh}_{2}\right), 7.64-7.51(\mathrm{~m}, 12 \mathrm{H}, \mathrm{H3}$ of PAr overlapping with $m$ of $\mathrm{PPh}_{2}, O$ of $\mathrm{PPh}_{2}$ and $m$ of $\left.\mathrm{PPh}_{2}\right)$, $7.45\left(\mathrm{~m}, 4 \mathrm{H}, o\right.$ of $\left.\mathrm{PPh}_{2}\right), 6.86(\mathrm{~m}, 2 \mathrm{H}, m$ of $\mathrm{BBn}), 6.77(\mathrm{~m}, 1 \mathrm{H}, p$ of $B B n$ overlapping with $O$ of $B B n), 6.73(m, 2 H, p$ of $B B n$ overlapping with $o$ of $\mathrm{BBn}), 6.63\left(\mathrm{dd},{ }^{3} \mathrm{~J}_{\mathrm{PH}}=15.3 \mathrm{~Hz},{ }^{4} \mathrm{~J}_{\mathrm{HH}}=1.2 \mathrm{~Hz}\right.$, $2 \mathrm{H}, \mathrm{H} 5$ of PAr), $3.95\left(\mathrm{~m}, 1 \mathrm{H}, \mathrm{CH}\right.$ of $\left.{ }^{i} \mathrm{Pr}\right), 3.50\left(\mathrm{~m}, 2 \mathrm{H}, \mathrm{CH}_{2} \mathrm{~N}\right), 3.33$ (m, $2 \mathrm{H}, \mathrm{CH}_{2} \mathrm{~N}$ ), 2.80 (bs, $2 \mathrm{H}, \mathrm{CH}_{2}$ of $\mathrm{BBn}$ ), 1.51 (s, $18 \mathrm{H}, \mathrm{CH}_{3}$ of $\left.{ }^{t} \mathrm{Bu}^{2}\right), 1.09\left(\mathrm{~s}, 18 \mathrm{H}, \mathrm{CH}_{3}\right.$ of $\left.{ }^{t} \mathrm{Bu}^{4}\right), 0.73\left(\mathrm{~d}, 6 \mathrm{H},{ }^{3} \mathrm{JHH}_{\mathrm{HH}}=5.8 \mathrm{~Hz}, \mathrm{CH}_{3}\right.$ of i Pr). ${ }^{13} \mathrm{C}\left\{{ }^{1} \mathrm{H}\right\}$ NMR (151 MHz, $\mathrm{CD}_{2} \mathrm{Cl}_{2}, 300 \mathrm{~K}$ ): $\delta=162.0$ (s, $\mathrm{C} 1$ of $\mathrm{PAr}), 149.1$ (s, $i$ of $\mathrm{BBn}), 148.6\left(\mathrm{dm},{ }^{1} J_{\mathrm{CF}}=238 \mathrm{~Hz}, \mathrm{CF}\right.$ of $\left.\mathrm{C}_{6} \mathrm{~F}_{5}\right)$, $142.8\left(d,{ }^{3} J_{\mathrm{CP}}=14.0 \mathrm{~Hz}, \mathrm{C} 4\right.$ of PAr), $139.1\left(\mathrm{~d},{ }^{3} J_{\mathrm{CP}}=7.0 \mathrm{~Hz}, \mathrm{C} 2\right.$ of PAr), $137.9\left(\mathrm{dm},{ }^{1} J_{\mathrm{CF}}=243 \mathrm{~Hz}, \mathrm{CF}\right.$ of $\left.\mathrm{C}_{6} \mathrm{~F}_{5}\right), 136.8\left(\mathrm{dm},{ }^{1} J_{\mathrm{CF}}=245\right.$ $\mathrm{Hz}, \mathrm{CF}$ of $\left.\mathrm{C}_{6} \mathrm{~F}_{5}\right), 134.1\left(\mathrm{~m}, p\right.$ of $\left.\mathrm{PPh}_{2}\right), 133.3\left(\mathrm{~d},{ }^{2} \mathrm{~J}_{\mathrm{CP}}=10.0 \mathrm{~Hz}, o\right.$ of $\left.\mathrm{PPh}_{2}\right), 133.2\left(\mathrm{~d},{ }^{2} J_{\mathrm{CP}}=10.2 \mathrm{~Hz}\right.$, o of $\left.\mathrm{PPh}_{2}\right), 131.0$ (s, C3 of PAr), $130.0\left(\mathrm{~m}, \mathrm{~m}\right.$ of $\left.\mathrm{PPh}_{2}\right), 129.0$ (s, o of $\left.\mathrm{BBn}\right), 128.8$ (n.o., $i$ of $\mathrm{C}_{6} \mathrm{~F}_{5}$ visible in $\mathrm{HMBC}$ ), 127.7 ( $d,{ }^{2} \mathrm{~J}_{\mathrm{CP}}=13.6 \mathrm{~Hz}, \mathrm{C} 5$ of $\left.\mathrm{PAr}\right), 127.1$ (s, $m$ of $\mathrm{BBn}$ overlapping with $i$ of $\left.\mathrm{PPh}_{2}\right), 126.8\left(\mathrm{~d},{ }^{1} J_{\mathrm{CP}}=93.4 \mathrm{~Hz}, i\right.$ of $\mathrm{PPh}_{2}$ overlapping with $i$ of $\mathrm{PPh}_{2}$ and $m$ of $\left.\mathrm{BBn}\right), 126.0\left(\mathrm{~d},{ }^{1} J_{\mathrm{CP}}=\right.$ 93.8 Hz, $i$ of $\mathrm{PPh}_{2}$ overlapping with $i$ of $\left.\mathrm{PPh}_{2}\right), 122.6$ (s, $p$ of $\mathrm{BBn}$ ), $111.6\left(\mathrm{~d},{ }^{1} J_{\mathrm{CP}}=115.0 \mathrm{~Hz}\right.$, $i$ of $\mathrm{PAr}$ ), 76.1 (bs, $\mathrm{CH}$ of ${ }^{i} \mathrm{Pr}$ ), 52.0 (dd, $\left.{ }^{3} J_{\mathrm{CP}}=16.2 \mathrm{~Hz},{ }^{2} \mathrm{~J}_{\mathrm{CP}}=4.1 \mathrm{~Hz}, \mathrm{NCH}_{2}\right), 36.1\left(\mathrm{~s}, \mathrm{C}\right.$ of $\left.{ }^{t} \mathrm{Bu}^{2}\right), 34.7(\mathrm{~s}, \mathrm{C}$ of ${ }^{t} \mathrm{Bu}^{4}$ ), 32.0 (n.o., $\mathrm{CH}_{2}$ of $\mathrm{BBn}$ visible in $\mathrm{HSQC}$ ), 31.2 (s, $C$ of ${ }^{t} \mathrm{Bu}^{4}$ ), 30.2 (s, $\mathrm{CH}_{3}$ of ${ }^{t} \mathrm{Bu}^{2}$ ), 26.2 (bs, $\mathrm{CH}_{3}$ of ${ }^{\mathrm{i}} \mathrm{Pr}$ ). ${ }^{19} \mathrm{~F}\left\{{ }^{1} \mathrm{H}\right\} \mathrm{NMR}(565 \mathrm{MHz}$, $\left.\mathrm{CD}_{2} \mathrm{Cl}_{2}, 300 \mathrm{~K}\right): \delta=-131.4\left(\mathrm{~m}, o\right.$ of $\left.\mathrm{C}_{6} \mathrm{~F}_{5}\right),-165.1\left(\mathrm{t}, \mathrm{J}_{\mathrm{FF}}=20.5 \mathrm{~Hz}\right.$, $p$ of $\left.\mathrm{C}_{6} \mathrm{~F}_{5}\right),-167.9\left(\mathrm{t}, \mathrm{J}_{\mathrm{FF}}=19.9 \mathrm{~Hz}, m\right.$ of $\left.\mathrm{C}_{6} \mathrm{~F}_{5}\right) .{ }^{11} \mathrm{~B}\left\{{ }^{1} \mathrm{H}\right\}$ NMR $(192$ $\left.\mathrm{MHz}, \mathrm{CD}_{2} \mathrm{Cl}_{2}, 300 \mathrm{~K}\right): \delta=-12.8$. Elemental Analysis: calculated for $\mathrm{C}_{82} \mathrm{H}_{78} \mathrm{BF}_{15} \mathrm{~N}_{2} \mathrm{O}_{3} \mathrm{P}_{2} \mathrm{Zr}\left(\mathrm{C}_{5} \mathrm{H}_{12}\right)_{0.5}$ : C, 62.55; $\mathrm{H}, 5.22 ; \mathrm{N}, 1.72$. Found: $\mathrm{C}, 61.93 ; \mathrm{H}, 4.96 ; \mathrm{N}, 1.32$. HRMS (ESI-pos): calculated for $\mathrm{C}_{57} \mathrm{H}_{71} \mathrm{~N}_{2} \mathrm{O}_{3} \mathrm{P}_{2} \mathrm{Zr}^{+} \quad\left[\mathrm{M}-\mathrm{B}\left(\mathrm{C}_{6} \mathrm{~F}_{5}\right)_{3} \mathrm{CH}_{2} \mathrm{Ph}\right]^{+}:$983.39815. Found: 983.38712 (-11.2 ppm). Calculated for $\mathrm{C}_{55} \mathrm{H}_{67} \mathrm{~N}_{2} \mathrm{O}_{3} \mathrm{P}_{2} \mathrm{Zr}^{+}[\mathrm{M}-$ $\left.\mathrm{B}\left(\mathrm{C}_{6} \mathrm{~F}_{5}\right)_{3} \mathrm{CH}_{2} \mathrm{Ph}-\mathrm{O}^{\mathrm{i} P r}+\mathrm{MeO}\right]^{+}:$955.36685. Found: 955.36372 (-3.3 $\mathrm{ppm})$.

\section{Synthesis of complex $6 a$}

Complex 4a (0.339 g, $0.2 \mathrm{mmol})$ was dissolved in $6 \mathrm{~mL}$ of $\mathrm{CH}_{2} \mathrm{Cl}_{2}$ and (-)-L-methyl lactate $(21 \mathrm{mg}, 0.2 \mathrm{mmol}$ ) was added to the solution. The reaction mixture was stirred for $20 \mathrm{~min}$, then it was evaporated to dryness, and the residue was triturated in 5 $\mathrm{mL}$ of pentane. The supernatant solution was discarded and the residue was dried under vacuum, yielding complex $6 \mathbf{a}$ as a white powder containing $90 \mathrm{~mol} \%$ of pentane and $10 \mathrm{~mol} \%$ of toluene (0.240 g, $86 \%$ ). ${ }^{31} \mathrm{P}\left\{{ }^{1} \mathrm{H}\right\}$ NMR (243 MHz, $\left.\mathrm{CD}_{2} \mathrm{Cl}_{2}, 298 \mathrm{~K}\right): \delta=37.7$ $\left(v_{1 / 2} \approx 3 \mathrm{~Hz}\right), 37.5\left(v_{1 / 2} \approx 3 \mathrm{~Hz}\right) .{ }^{1} \mathrm{H}$ NMR $\left(600 \mathrm{MHz}, \mathrm{CD}_{2} \mathrm{Cl}_{2}, 298\right.$ K): $\delta=7.73-7.66\left(\mathrm{~m}, 2 \mathrm{H}, p\right.$ of $\mathrm{PPh}_{2}$ overlapping with $p$ of $\left.\mathrm{PPh}_{2}\right)$, 7.65-7.55 $\left(\mathrm{m}, 12 \mathrm{H}, p\right.$ of $\mathrm{PPh}_{2}$ overlapping with $\mathrm{H3}$ of PAr and $o$ and $m$ of $\left.\mathrm{PPh}_{2}\right), 7.46-7.36\left(\mathrm{~m}, 8 \mathrm{H}, m\right.$ of $\mathrm{PPh}_{2}$ overlapping with $o$ of $\left.\mathrm{PPh}_{2}\right), 6.86(\mathrm{~m}, 2 \mathrm{H}, m$ of $\mathrm{BBn}), 6.81-6.71(\mathrm{~m}, 5 \mathrm{H}, p$ of $\mathrm{BBn}$ overlapping with $O$ of $\mathrm{BBn}$ and $\mathrm{H} 5$ of PAr), $4.84\left(\mathrm{q},{ }^{3} \mathrm{JHH}_{\mathrm{HH}}=7.0 \mathrm{~Hz}\right.$, $1 \mathrm{H}, \mathrm{CH}$ of lactate), $3.68\left(\mathrm{~s}, 3 \mathrm{H}, \mathrm{OCH}_{3}\right.$ of lactate), $3.48(\mathrm{~m}, 2 \mathrm{H}$, $\left.\mathrm{CH}_{2} \mathrm{~N}\right), 3.09\left(\mathrm{~m}, 2 \mathrm{H}, \mathrm{CH}_{2} \mathrm{~N}\right), 2.81$ (bs, $2 \mathrm{H}, \mathrm{CH}_{2}$ of $\left.\mathrm{BBn}\right), 1.36(\mathrm{~s}, 9 \mathrm{H}$, $\mathrm{CH}_{3}$ of $\left.{ }^{t} \mathrm{Bu}^{2}\right), 1.34\left(\mathrm{~s}, 9 \mathrm{H}, \mathrm{CH}_{3}\right.$ of $\left.{ }^{t} \mathrm{Bu}^{2}\right), 1.30\left(\mathrm{~d},{ }^{3} \mathrm{~J}_{\mathrm{HH}}=7.0 \mathrm{~Hz}, 3 \mathrm{H}\right.$, $\mathrm{CH}_{3}$ of lactate), $1.15\left(\mathrm{~s}, 18 \mathrm{H}, \mathrm{CH}_{3}\right.$ of $\left.{ }^{t} \mathrm{Bu}^{4}\right) .{ }^{13} \mathrm{C}\left\{{ }^{1} \mathrm{H}\right\}$ NMR (151 
$\mathrm{MHz}, \mathrm{CD}_{2} \mathrm{Cl}_{2}, 298 \mathrm{~K}$ ): $\delta=192.9$ (s, C=O of lactate), 162.6 (d, ${ }^{2} J_{\mathrm{PC}}$ $=1.6 \mathrm{~Hz}, C 1$ of PAr), 162.5 (d, ${ }^{2} J_{\mathrm{PC}}=1.8 \mathrm{~Hz}, \mathrm{C} 1$ of PAr), $149.1(\mathrm{~s}, i$ of BBn overlapping with $C F$ of $\left.C_{6} F_{5}\right), 148.6\left(\mathrm{dm},{ }^{1} J_{\mathrm{CF}}=237 \mathrm{~Hz}, \mathrm{CF}\right.$ of $\left.\mathrm{C}_{6} \mathrm{~F}_{5}\right), 142.1\left(\mathrm{~d},{ }^{3} \mathrm{~J}_{\mathrm{CP}}=12.7 \mathrm{~Hz}, \mathrm{C} 4\right.$ of PAr overlapping with $\mathrm{C} 4$ of PAr), $142.1\left(\mathrm{~d},{ }^{3} \mathrm{~J}_{\mathrm{CP}}=12.7 \mathrm{~Hz}, \mathrm{C} 4\right.$ of PAr overlapping with $\mathrm{C} 4$ of PAr), $139.3\left(\mathrm{~d},{ }^{3} \mathrm{~J}_{\mathrm{CP}}=6.7 \mathrm{~Hz}, \mathrm{C2}\right.$ of PAr overlapping with $\mathrm{C} 2$ of PAr), $139.2\left(d,{ }^{3} J_{C P}=6.7 \mathrm{~Hz}, C 2\right.$ of PAr overlapping with $C 2$ of $\mathrm{PAr}), 137.9\left(\mathrm{dm},{ }^{1} J_{\mathrm{CF}}=243 \mathrm{~Hz}, C F\right.$ of $\mathrm{C}_{6} \mathrm{~F}_{5}$ overlapping with $C F$ of $\left.\mathrm{C}_{6} \mathrm{~F}_{5}\right), 136.7\left(\mathrm{dm},{ }^{1} \mathrm{~J}_{\mathrm{CF}}=246 \mathrm{~Hz}, C F\right.$ of $\mathrm{C}_{6} \mathrm{~F}_{5}$ overlapping with $C F$ of $\left.\mathrm{C}_{6} \mathrm{~F}_{5}\right), 134.0\left(\mathrm{~d},{ }^{4} \mathrm{~J}_{\mathrm{PC}}=2.8 \mathrm{~Hz}, p\right.$ of $\left.\mathrm{PPh}_{2}\right), 133.9\left(\mathrm{~d},{ }^{4} J_{\mathrm{PC}}=2.8 \mathrm{~Hz}, p\right.$ of $\left.\mathrm{PPh}_{2}\right), 133.7\left(\mathrm{~d},{ }^{4} \mathrm{~J}_{\mathrm{PC}}=2.7 \mathrm{~Hz}, p\right.$ of $\left.\mathrm{PPh}_{2}\right), 133.6\left(\mathrm{~m}, p\right.$ of $\mathrm{PPh}_{2}$ overlapping with $O$ of $\left.\mathrm{PPh}_{2}\right), 133.6\left(\mathrm{~d},{ }^{2} J_{\mathrm{CP}}=9.9 \mathrm{~Hz}, o\right.$ of $\mathrm{PPh}_{2}$ overlapping with $p$ of $\left.P P h_{2}\right), 133.5\left(d,{ }^{2} J_{C P}=10.2 \mathrm{~Hz}, o\right.$ of $\left.P P h_{2}\right)$, $133.1\left(\mathrm{~d},{ }^{2} J_{\mathrm{CP}}=2.2 \mathrm{~Hz}\right.$, o of $\left.\mathrm{PPh}_{2}\right), 133.0\left(\mathrm{~d},{ }^{2} J_{\mathrm{CP}}=2.1 \mathrm{~Hz}, o\right.$ of $\mathrm{PPh}_{2}$ ), $130.6\left(\mathrm{~d},{ }^{4} J_{\mathrm{CP}}=1.9 \mathrm{~Hz}, \mathrm{C} 3\right.$ of PAr), $130.6\left(\mathrm{~d},{ }^{4} J_{\mathrm{CP}}=1.9 \mathrm{~Hz}\right.$, $C 3$ of PAr), $129.8\left(\mathrm{~d},{ }^{3} J_{\mathrm{CP}}=3.0 \mathrm{~Hz}, m\right.$ of $\mathrm{PPh}_{2}$ overlapping with $m$ of $\left.P P h_{2}\right), 129.8\left(d, 3 J_{C P}=2.2 \mathrm{~Hz}, m\right.$ of $P P h_{2}$ overlapping with two $m$ of $\left.\mathrm{PPh}_{2}\right), 129.7\left(\mathrm{~d},{ }^{3} \mathrm{~J}_{\mathrm{CP}}=3.2 \mathrm{~Hz}, m\right.$ of $\mathrm{PPh}_{2}$ overlapping with two $m$ of $\left.\mathrm{PPh}_{2}\right), 129.7\left(\mathrm{~d},{ }^{3} J_{\mathrm{CP}}=1.9 \mathrm{~Hz}, m\right.$ of $\mathrm{PPh}_{2}$ overlapping with $m$ of $\mathrm{PPh}_{2}$ ), 129.1 (s, $o$ of $\mathrm{BBn}$ ), 128.8 (n.o., $i$ of $\mathrm{C}_{6} \mathrm{~F}_{5}$ visible in $\mathrm{HMBC}$ ), 127.6-124.9 (m, four overlapping $i$ of $\mathrm{PPh}_{2}$ overlapping with two $\mathrm{C} 5$ of PAr and $m$ of $\mathrm{BBn}), 127.2\left(\mathrm{~d},{ }^{2} \mathrm{~J}_{\mathrm{CP}}=\right.$ 13.0 Hz, C5 of PAr overlapping with $i$ of $\left.\mathrm{PPh}_{2}\right), 127.1$ (d, ${ }^{2} J_{\mathrm{CP}}=$ 13.2 Hz, C5 of PAr overlapping with $i$ of $\mathrm{PPh}_{2}$ and $m$ of $\left.\mathrm{BBn}\right)$, 127.1 (s, $m$ of BBn overlapping with $C 5$ of PAr and $i$ of $\mathrm{PPh}_{2}$ ), 122.6 (s, $p$ of $\mathrm{BBn}$ ), 112.2 (d, ${ }^{1} J_{\mathrm{CP}}=50.0 \mathrm{~Hz}, \mathrm{C6}$ of PAr), 111.5 (d, ${ }^{1} J_{\mathrm{CP}}=50.0 \mathrm{~Hz}, \mathrm{C} 6$ of PAr), 77.2 (s, CH of lactate), 56.6 (s, $\mathrm{OCH}_{3}$ of lactate), $52.1\left(\mathrm{dd},{ }^{3} J_{\mathrm{CP}}=12.8 \mathrm{~Hz},{ }^{2} J_{\mathrm{CP}}=3.9 \mathrm{~Hz}, \mathrm{NCH}_{2}\right), 51.9(\mathrm{dd}$, $\left.{ }^{3} J_{\mathrm{CP}}=11.8 \mathrm{~Hz},{ }^{2} J_{\mathrm{CP}}=4.0 \mathrm{~Hz}, \mathrm{NCH}_{2}\right), 35.7\left(\mathrm{~d}, 4 J_{\mathrm{PC}}=1.7 \mathrm{~Hz}, \mathrm{C}\right.$ of $\left.{ }^{t} \mathrm{Bu}^{2}\right), 35.7\left(\mathrm{~d},{ }^{4} J_{\mathrm{PC}}=1.7 \mathrm{~Hz}, C\right.$ of $\left.{ }^{t} \mathrm{Bu}^{2}\right), 34.7\left(\mathrm{~s}, C\right.$ of $\left.{ }^{t} \mathrm{Bu}^{4}\right), 32.1$ (bs, $\mathrm{CH}_{2}$ of $\mathrm{BBn}$ ), 31.4 (s, $\mathrm{CH}_{3}$ of ${ }^{t} \mathrm{Bu}^{4}$ overlapping with $\mathrm{CH}_{3}$ of ${ }^{t} \mathrm{Bu}^{4}$ ), 31.3 (s, $\mathrm{CH}_{3}$ of ${ }^{t} \mathrm{Bu}^{4}$ overlapping with $\mathrm{CH}_{3}$ of $\left.{ }^{t} \mathrm{Bu}^{4}\right), 29.9\left(\mathrm{~s}, \mathrm{CH}_{3}\right.$ of $\left.{ }^{t} \mathrm{Bu}^{2}\right), 29.8\left(\mathrm{~s}, \mathrm{CH}_{3}\right.$ of $\left.{ }^{t} \mathrm{Bu}^{2}\right), 21.4\left(\mathrm{~s}, \mathrm{CH}_{3}\right.$ of lactate). ${ }^{19} \mathrm{~F}\left\{{ }^{1} \mathrm{H}\right\}$ NMR (565 MHz, $\left.\mathrm{CD}_{2} \mathrm{Cl}_{2}, 298 \mathrm{~K}\right): \delta=-131.4\left(\mathrm{~m}\right.$, o of $\left.\mathrm{C}_{6} \mathrm{~F}_{5}\right),-165.1(\mathrm{~m}, p$ of $\left.\mathrm{C}_{6} \mathrm{~F}_{5}\right),-167.8\left(\mathrm{~m}, \mathrm{~m}\right.$ of $\left.\mathrm{C}_{6} \mathrm{~F}_{5}\right) .{ }^{11} \mathrm{~B}\left\{{ }^{1} \mathrm{H}\right\}$ NMR (192 $\mathrm{MHz}, \mathrm{CD}_{2} \mathrm{Cl}_{2}$, $298 \mathrm{~K}): \delta=-12.7$. Elemental Analysis: calculated for $\mathrm{C}_{83} \mathrm{H}_{78} \mathrm{BF}_{15} \mathrm{~N}_{2} \mathrm{O}_{5} \mathrm{P}_{2} \mathrm{Zr}\left(\mathrm{C}_{5} \mathrm{H}_{12}\right)_{0.9}\left(\mathrm{C}_{7} \mathrm{H}_{8}\right)_{0.1}: \mathrm{C}, 62.07 ; \mathrm{H}, 5.29 ; \mathrm{N}, 1.64$. Found: $\mathrm{C}, 61.14 ; \mathrm{H}, 5.43$; N, 1.48. HRMS (ESI-pos): calculated for $\mathrm{C}_{58} \mathrm{H}_{71} \mathrm{~N}_{2} \mathrm{O}_{5} \mathrm{P}_{2} \mathrm{Zr}^{+} \quad\left[\mathrm{M}-\mathrm{B}\left(\mathrm{C}_{6} \mathrm{~F}_{5}\right)_{3} \mathrm{CH}_{2} \mathrm{Ph}\right]^{+}$: 1027.38798. Found: 1027.38350 (-4.4 ppm). Calculated for $\mathrm{C}_{55} \mathrm{H}_{67} \mathrm{~N}_{2} \mathrm{O}_{3} \mathrm{P}_{2} \mathrm{Zr}^{+}[\mathrm{M}-$ $\mathrm{B}\left(\mathrm{C}_{6} \mathrm{~F}_{5}\right)_{3} \mathrm{CH}_{2} \mathrm{Ph}$-lactate+MeO]+: 955.36685. Found: 955.36399 ($3.0 \mathrm{ppm})$.

\section{Synthesis of complex $6 \mathrm{~b}$}

Complex 4b (0.435 g, $0.25 \mathrm{mmol})$ and (-)-L-methyl lactate (26 $\mathrm{mg}, 0.25 \mathrm{mmol}$ ) were dissolved in $5 \mathrm{~mL}$ of $\mathrm{CH}_{2} \mathrm{Cl}_{2}$ and the reaction mixture was stirred at room temperature for $30 \mathrm{~min}$. The volatiles were removed under vacuum to give an foamy solid, which was triturated in pentane $(5 \mathrm{~mL})$ to give a lightbrown oil. The supernatant solution was removed and the oil was washed with pentane $(5 \times 3 \mathrm{~mL})$, then dried under vacuum to give $\mathbf{6 b}$ as a white powder containing $100 \mathrm{~mol} \%$ of pentane (0.355 g, 85\%). ${ }^{31} \mathrm{P}\left\{{ }^{1} \mathrm{H}\right\}$ NMR (202 MHz, $\left.\mathrm{CD}_{2} \mathrm{Cl}_{2}, 298 \mathrm{~K}\right): \delta=33.1$ $\left(v_{1 / 2} \approx 3 \mathrm{~Hz}\right), 31.6\left(v_{1 / 2} \approx 3 \mathrm{~Hz}\right) .{ }^{1} \mathbf{H}$ NMR $\left(500 \mathrm{MHz}, \mathrm{CD}_{2} \mathrm{Cl}_{2}, 298\right.$ K): $\delta=7.81-7.72\left(\mathrm{~m}, 2 \mathrm{H}, p\right.$ of $\left.\mathrm{PPh}_{2}\right), 7.67-7.54(\mathrm{~m}, 12 \mathrm{H}, \mathrm{o} / \mathrm{m}$ of $\mathrm{PPh}_{2}$ overlapping with $p$ of PAr and $\mathrm{H3}$ of NAr), 7.53-7.40 $(\mathrm{m}, 6 \mathrm{H}$, $o$ of $\mathrm{PPh}_{2}$ overlapping with $p$ of $\left.\mathrm{PPh}_{2}\right), 7.32\left(\mathrm{~m}, 2 \mathrm{H}, m\right.$ of $\left.\mathrm{PPh}_{2}\right)$, $7.19\left(\mathrm{~m}, 2 \mathrm{H}, \mathrm{m}\right.$ of $\left.\mathrm{PPh}_{2}\right), 6.89(\mathrm{~m}, 1 \mathrm{H}, \mathrm{H} 5$ of PAr overlapping with $m$ of $\mathrm{BBn}), 6.87(\mathrm{~m}, 2 \mathrm{H}, m$ of BBn overlapping with $\mathrm{H} 5$ of PAr), $6.81(\mathrm{~m}, 1 \mathrm{H}, \mathrm{H} 5$ of PAr overlapping with $o$ of $\mathrm{BBn}), 6.78(\mathrm{~m}, 1 \mathrm{H}$, $p$ of $B B n$ overlapping with $H 5$ of PAr and $p$ of $B B n), 6.76(\mathrm{~m}, 2 \mathrm{H}$, $o$ of $B B n$ overlapping with $p$ of $B B n), 6.42(m, 1 \mathrm{H}, H 3$ of $N A r$ overlapping with $\mathrm{H} 3$ of $\mathrm{NAr}), 6.39(\mathrm{~m}, 1 \mathrm{H}, \mathrm{H} 3$ of NAr overlapping with $\mathrm{H} 3$ of NAr), $6.20(\mathrm{~m}, 1 \mathrm{H}, \mathrm{H} 2$ of NAr), $6.16(\mathrm{~m}, 1 \mathrm{H}, \mathrm{H} 2$ of NAr), $4.61\left(\mathrm{q}, 1 \mathrm{H}, 3 \mathrm{~J}_{\mathrm{HH}}=7.0 \mathrm{~Hz}, \mathrm{CH}\right.$ of lactate), $3.58\left(\mathrm{~s}, 3 \mathrm{H}, \mathrm{OCH}_{3}\right.$ of lactate), 2.82 (bs, $2 \mathrm{H}, \mathrm{CH}_{2}$ of $\left.\mathrm{BBn}\right), 1.25-1.178\left(\mathrm{~m}, 39 \mathrm{H},{ }^{t} \mathrm{Bu}\right.$ overlapping with $\mathrm{CH}_{3}$ of lactate). ${ }^{13} \mathbf{C}\left\{{ }^{1} \mathrm{H}\right\}$ NMR $\left(126 \mathrm{MHz}, \mathrm{CD}_{2} \mathrm{Cl}_{2}\right.$, $298 \mathrm{~K}$ ): 192.8 (s, C=O of lactate), 162.6 (m, C1 of PAr), 162.4 (d, ${ }^{2} J_{\mathrm{PC}}=1.1 \mathrm{~Hz}, C 1$ of PAr), 149.2 (s, $i$ of BBn overlapping with CF of $\left.\mathrm{C}_{6} \mathrm{~F}_{5}\right), 148.6\left(\mathrm{dm},{ }^{1} J_{\mathrm{CF}}=238 \mathrm{~Hz}, \mathrm{CF}\right.$ of $\left.\mathrm{C}_{6} \mathrm{~F}_{5}\right), 142.6\left(\mathrm{~d},{ }^{3} \mathrm{~J}_{\mathrm{PC}}=14.5\right.$ $\mathrm{Hz}, \mathrm{C} 4$ of PAr overlapping with C4 of PAr), $142.5\left(\mathrm{~d}, 3^{3} \mathrm{PC}_{\mathrm{PC}}=15.1\right.$ $\mathrm{Hz}, \mathrm{C} 4$ of PAr overlapping with $\mathrm{C} 4$ of PAr), $141.6\left(\mathrm{dd},{ }^{3} \mathrm{CP}_{\mathrm{CP}}=12.9\right.$ $\mathrm{Hz},{ }^{2} J_{\mathrm{CP}}=3.6 \mathrm{~Hz}, \mathrm{C} 1$ of $\left.\mathrm{NAr}\right), 141.1\left(\mathrm{dd},{ }^{3} J_{\mathrm{CP}}=14.1 \mathrm{~Hz},{ }^{3} J_{\mathrm{CP}}=3.7 \mathrm{~Hz}\right.$, $\mathrm{C} 1$ of NAr), $139.4\left(\mathrm{~d},{ }^{3} J_{\mathrm{CP}}=1.9 \mathrm{~Hz}, \mathrm{C} 2\right.$ of PAr overlapping with $\mathrm{C} 2$ of PAr), $139.4\left(d,{ }^{3} J_{C P}=1.7 \mathrm{~Hz}, C 2\right.$ of PAr overlapping with $\mathrm{C} 2$ of PAr), $138.0\left(\mathrm{dm},{ }^{1} J_{\mathrm{CF}}=242 \mathrm{~Hz}, C F\right.$ of $\mathrm{C}_{6} \mathrm{~F}_{5}$ overlapping with $\mathrm{CF}$ of $\left.\mathrm{C}_{6} \mathrm{~F}_{5}\right), 136.7\left(\mathrm{dm},{ }^{1} J_{\mathrm{CF}}=248 \mathrm{~Hz}, \mathrm{CF}\right.$ of $\mathrm{C}_{6} \mathrm{~F}_{5}$ overlapping with $\mathrm{CF}$ of $\left.\mathrm{C}_{6} \mathrm{~F}_{5}\right), 134.7\left(\mathrm{~d},{ }^{4} \mathrm{~J}_{\mathrm{CP}}=2.5 \mathrm{~Hz}, p\right.$ of $\left.\mathrm{PPh}_{2}\right), 134.5\left(\mathrm{~d},{ }^{4} J_{\mathrm{CP}}=2.6 \mathrm{~Hz}, p\right.$ of $\mathrm{PPh}_{2}$ overlapping with $o$ of $\left.\mathrm{PPh}_{2}\right), 134.4\left(\mathrm{~d},{ }^{2} J_{\mathrm{CP}}=10.9 \mathrm{~Hz}, o\right.$ of $\mathrm{PPh}_{2}$ overlapping with $p$ of $\left.\mathrm{PPh}_{2}\right), 134.1\left(\mathrm{~d},{ }^{4} J_{\mathrm{CP}}=2.8 \mathrm{~Hz}, p\right.$ of $\mathrm{PPh}_{2}$ overlapping with $O$ of $\left.\mathrm{PPh}_{2}\right), 134.1\left(\mathrm{~d},{ }^{2} J_{\mathrm{CP}}=11.3 \mathrm{~Hz}, O\right.$ of $\mathrm{PPh}_{2}$ overlapping with two $p$ of $\left.\mathrm{PPh}_{2}\right), 133.9\left(\mathrm{~d},{ }^{4} J_{\mathrm{CP}}=2.7 \mathrm{~Hz}, p\right.$ of $\mathrm{PPh}_{2}$ overlapping with $o$ of $\left.\mathrm{PPh}_{2}\right), 133.5\left(\mathrm{~d},{ }^{2} \mathrm{~J}_{\mathrm{CP}}=10.2 \mathrm{~Hz}, o\right.$ of $\left.\mathrm{PPh}_{2}\right)$, $133.2\left(\mathrm{~d},{ }^{2} J_{\mathrm{CP}}=10.3 \mathrm{~Hz}, o\right.$ of $\left.\mathrm{PPh}_{2}\right), 131.2-131.0$ (m, C3 of PAr), $130.0\left(\mathrm{~d},{ }^{3} J_{\mathrm{PC}}=2.8 \mathrm{~Hz}, \mathrm{~m}\right.$ of $\mathrm{PPh}_{2}$ overlapping with two $m$ of $\left.\mathrm{PPh}_{2}\right), 129.9\left(\mathrm{~d},{ }^{3} \mathrm{~J}_{\mathrm{PC}}=12.6 \mathrm{~Hz}, m\right.$ of $\mathrm{PPh}_{2}$ overlapping with three $m$ of $\left.\mathrm{PPh}_{2}\right), 129.9\left(\mathrm{~d},{ }^{3} \mathrm{JP}_{\mathrm{PC}}=2.8 \mathrm{~Hz}, m\right.$ of $\mathrm{PPh}_{2}$ overlapping with three $m$ of $\left.\mathrm{PPh}_{2}\right), 129.7\left(\mathrm{~d},{ }^{3} \mathrm{JC}_{\mathrm{PC}}=12.6 \mathrm{~Hz}, m\right.$ of $\mathrm{PPh}_{2}$ overlapping with two $m$ of $\mathrm{PPh}_{2}$ ), 129.1 (s, o of BBn), 128.3-125.4 (m, four overlapping $i$ of $\mathrm{PPh}_{2}$ overlapping with two $\mathrm{C} 5$ of PAr and $\mathrm{m}$ of $\mathrm{BBn}), 128.0\left(\mathrm{~d},{ }^{2} \mathrm{~J}_{\mathrm{CP}}=12.9 \mathrm{~Hz}, \mathrm{C} 5\right.$ of PAr overlapping with $i$ of $\left.\mathrm{PPh}_{2}\right), 127.7\left(\mathrm{~d},{ }^{2} J_{\mathrm{CP}}=13.2 \mathrm{~Hz}, \mathrm{C} 5\right.$ of PAr overlapping with $i$ of $\mathrm{PPh}_{2}$ ), 127.1 (s, $m$ of $\mathrm{BBn}$ overlapping with $i$ of $\left.\mathrm{PPh}_{2}\right) 122.7$ (s, $p$ of $B B n), 122.5$ (s, C3 of NAr), $122.3\left(d,{ }^{3} J_{C P}=5.3 \mathrm{~Hz}, C 2\right.$ of NAr), 122.1 (s, C3 of NAr), 121.9 (d, $3 J_{\mathrm{CP}}=5.6 \mathrm{~Hz}, \mathrm{C} 2$ of NAr), 112.1111.1 (m, two overlapping $\mathrm{C6}$ of PAr), 77.7 (s, CH of lactate), $56.6\left(\mathrm{~s}, \mathrm{OCH}_{3}\right.$ of lactate), $35.6\left(\mathrm{~m}\right.$, two overlapping $C$ of $\left.{ }^{t} \mathrm{Bu}^{2}\right)$, 34.8 (s, $C$ of ${ }^{t} \mathrm{Bu}^{4}$ overlapping with $\mathrm{C}$ of ${ }^{t} \mathrm{Bu}^{4}$ ), 34.8 (s, $C$ of ${ }^{t} \mathrm{Bu}^{4}$ overlapping with $\mathrm{C}$ of ${ }^{t} \mathrm{Bu}^{4}$ ), 31.9 (n.o., $\mathrm{CH}_{2}$ of $\mathrm{BBn}$, visible in HSQC spectrum), $31.4\left(\mathrm{~s}, \mathrm{CH}_{3}\right.$ of $\left.{ }^{\mathrm{t}} \mathrm{Bu}^{4}\right), 29.7\left(\mathrm{~s}, \mathrm{CH}_{3}\right.$ of ${ }^{t} \mathrm{Bu}^{2}$ overlapping with $\mathrm{CH}_{3}$ of $\left.{ }^{t} \mathrm{Bu}^{2}\right), 29.6\left(\mathrm{~s}, \mathrm{CH}_{3}\right.$ of ${ }^{t} \mathrm{Bu}^{2}$ overlapping with $\mathrm{CH}_{3}$ of $\left.{ }^{t} \mathrm{Bu}^{2}\right), 21.4$ (s, $\mathrm{CH}_{3}$ of lactate). ${ }^{19} \mathrm{~F}\left\{{ }^{1} \mathrm{H}\right\} \mathrm{NMR}(470 \mathrm{MHz}$, $\left.\mathrm{CD}_{2} \mathrm{Cl}_{2}, 298 \mathrm{~K}\right): \delta=-131.3\left(\mathrm{~m}, o\right.$ of $\left.\mathrm{C}_{6} \mathrm{~F}_{5}\right),-165.0\left(\mathrm{~m}, p\right.$ of $\left.\mathrm{C}_{6} \mathrm{~F}_{5}\right)$, $167.8\left(\mathrm{~m}, \mathrm{~m}\right.$ of $\left.\mathrm{C}_{6} \mathrm{~F}_{5}\right) .{ }^{11} \mathrm{~B}\left\{{ }^{1} \mathrm{H}\right\}$ NMR (160 MHz, $\left.\mathrm{CD}_{2} \mathrm{Cl}_{2}, 298 \mathrm{~K}\right): \delta$ $=-12.7$. Elemental Analysis: calculated for $\mathrm{C}_{87} \mathrm{H}_{78} \mathrm{BF}_{15} \mathrm{~N}_{2} \mathrm{O}_{5} \mathrm{P}_{2} \mathrm{Zr}\left(\mathrm{C}_{5} \mathrm{H}_{12}\right)$ : C, 63.05; $\mathrm{H}, 5.18 ; \mathrm{N}, 1.64$. Found: $\mathrm{C}$, 62.24; $\mathrm{H}, 5.27 ; \mathrm{N}, 1.60$. HRMS (ESI-pos): calculated for $\mathrm{C}_{62} \mathrm{H}_{71} \mathrm{~N}_{2} \mathrm{O}_{5} \mathrm{P}_{2} \mathrm{Zr}+\quad\left[\mathrm{M}-\mathrm{B}\left(\mathrm{C}_{6} \mathrm{~F}_{5}\right)_{3} \mathrm{CH}_{2} \mathrm{Ph}\right]^{+}:$1075.38790. Found: 1075.38799 (+0.0 ppm). Calculated for $\mathrm{C}_{58} \mathrm{H}_{65} \mathrm{~N}_{2} \mathrm{O}_{3} \mathrm{P}_{2} \mathrm{Zr}^{+}[\mathrm{M}-$ $\mathrm{B}\left(\mathrm{C}_{6} \mathrm{~F}_{5}\right)_{3} \mathrm{CH}_{2} \mathrm{Ph}$-lactate+OH$]^{+}$: 989.35175 . Found: 989.35238 ($0.6 \mathrm{ppm})$.

\section{Synthesis of complex 7a}


Proligand $1 \mathbf{a H}_{\mathbf{2}}$ (419 $\left.\mathrm{mg}, 0.50 \mathrm{mmol}\right)$ was suspended in pentane and $\mathrm{Ti}\left(\mathrm{NMe}_{2}\right)_{4}(112 \mathrm{mg}, 0.50 \mathrm{mmol}$ ) was added dropwise. The mixture was stirred for $45 \mathrm{~min}$ during which a red-orange precipitate appeared. The solid was filtered, rinsed with $2 \mathrm{~mL}$ of pentane and dried under vacuum, affording complex 7a (362 $\mathrm{mg}, 72 \%)$ containing $50 \mathrm{~mol} \%$ of pentane. ${ }^{31} \mathrm{P}\left\{{ }^{1} \mathrm{H}\right\}$ NMR (202 MHz, $\mathbf{d}_{8}$-THF, $\left.300 \mathrm{~K}\right): \delta=32.0\left(\mathrm{v}_{1 / 2} \approx 3 \mathrm{~Hz}\right), 26.1\left(\mathrm{v}_{1 / 2} \approx 2 \mathrm{~Hz}\right) .{ }^{1} \mathbf{H}$ NMR (500 MHz, $\mathbf{d}_{\mathbf{8}}$-THF, $\left.300 \mathrm{~K}\right): \delta=8.01\left(\mathrm{~m}, 2 \mathrm{H}, \mathrm{o}\right.$ of $\left.\mathrm{PPh}_{2}\right), 7.58-$ $7.31(\mathrm{~m}, 18 \mathrm{H}, \mathrm{CH}-\mathrm{Ar}), 7.19\left(\mathrm{~m}, 2 \mathrm{H}, \mathrm{m}\right.$ of $\left.\mathrm{PPh}_{2}\right), 6.86\left(\mathrm{dd},{ }^{3} \mathrm{P}_{\mathrm{PH}}=\right.$ $12.9 \mathrm{~Hz},{ }^{4} J_{\mathrm{HH}}=2.7 \mathrm{~Hz}, 1 \mathrm{H}, H 5$ of PAr), $6.81\left(\mathrm{dd},{ }^{3} J_{\mathrm{PH}}=16.3 \mathrm{~Hz}\right.$, ${ }^{4} J_{\mathrm{HH}}=2.5 \mathrm{~Hz}, 1 \mathrm{H}, \mathrm{H} 5$ of PAr), $3.13\left(\mathrm{~s}, 6 \mathrm{H}, \mathrm{NMe}_{2}\right.$ overlapping with $\left.\mathrm{CH}_{2} \mathrm{~N}\right)$, 3.12-2.97 (m, $1 \mathrm{H}, \mathrm{CH}_{2} \mathrm{~N}$ overlapping with $\left.\mathrm{NMe}_{2}\right), 2.91(\mathrm{~m}$, $\left.1 \mathrm{H}, \mathrm{CH}_{2} \mathrm{~N}\right)$, 2.74-2.63 (m, $2 \mathrm{H}$, two overlapping $\left.\mathrm{CH}_{2} \mathrm{~N}\right), 2.60(\mathrm{~s}, 6 \mathrm{H}$, $\left.\mathrm{NMe}_{2}\right), 1.49\left(\mathrm{~s}, 9 \mathrm{H}, \mathrm{CH}_{3}\right.$ of $\left.{ }^{t} \mathrm{Bu}^{2}\right), 1.23\left(\mathrm{~s}, 9 \mathrm{H}, \mathrm{CH}_{3}\right.$ of $\left.{ }^{t} \mathrm{Bu}^{4}\right), 1.10$ (s, $9 \mathrm{H}, \mathrm{CH}_{3}$ of $\left.{ }^{t} \mathrm{Bu}^{4}\right), 1.02\left(\mathrm{~s}, 9 \mathrm{H}, \mathrm{CH}_{3}\right.$ of $\left.{ }^{t} \mathrm{Bu}^{2}\right) .{ }^{13} \mathrm{C}\left\{{ }^{1} \mathrm{H}\right\}$ NMR $(126 \mathrm{MHz}$, d $_{8}$-THF, $300 \mathrm{~K}$ ): $\delta=170.2$ (d, ${ }^{2} J_{\mathrm{PC}}=4.3 \mathrm{~Hz}, \mathrm{C1}$ of PAr), 169.9 (d, ${ }^{2} J_{\mathrm{PC}}=2.4 \mathrm{~Hz}, \mathrm{C} 1$ of PAr), $140.6\left(\mathrm{~d},{ }^{3} \mathrm{~J}_{\mathrm{CP}}=6.9 \mathrm{~Hz}, \mathrm{C} 2\right.$ of $\left.\mathrm{PAr}\right), 140.0$ (d, ${ }^{3} J_{\mathrm{CP}}=8.4 \mathrm{~Hz}, \mathrm{C2}$ of PAr), $137.1\left(\mathrm{~d},{ }^{3} \mathrm{~J}_{\mathrm{CP}}=14.6 \mathrm{~Hz}, \mathrm{C} 4\right.$ of PAr), $134.8\left(\mathrm{~m}\right.$, two overlapping $O$ of $\left.\mathrm{PPh}_{2}\right), 134.1\left(\mathrm{~d},{ }^{3} J_{\mathrm{CP}}=12.9 \mathrm{~Hz}, \mathrm{C} 4\right.$ of PAr overlapping with $i$ of $\left.\mathrm{PPh}_{2}\right), 134.1\left(\mathrm{~d},{ }^{1} J_{\mathrm{PC}}=88.2 \mathrm{~Hz}, i\right.$ of $\mathrm{PPh}_{2}$ overlapping with $\mathrm{C4}$ of PAr and two $O$ of $\mathrm{PPh}_{2}$ ), 133.8 (d, ${ }^{2} J_{\mathrm{CP}}=8.0 \mathrm{~Hz}, o$ of $\mathrm{PPh}_{2}$ overlapping with $i$ of $\mathrm{PPh}_{2}$ and $o$ of $\left.\mathrm{PPh}_{2}\right)$, $133.7\left(\mathrm{~d},{ }^{2} J_{\mathrm{CP}}=7.0 \mathrm{~Hz}, o\right.$ of $\mathrm{PPh}_{2}$ overlapping with $i$ of $\mathrm{PPh}_{2}$ and $o$ of $\left.\mathrm{PPh}_{2}\right), 132.7\left(\mathrm{~d},{ }^{1} \mathrm{JC}_{\mathrm{PC}}=116.5 \mathrm{~Hz}, i\right.$ of $\mathrm{PPh}_{2}$ overlapping with $p$ of $\left.\mathrm{PPh}_{2}\right), 132.3\left(\mathrm{~d},{ }^{4} \mathrm{~J}_{\mathrm{PC}}=2.3 \mathrm{~Hz}, p\right.$ of $\mathrm{PPh}_{2}$ overlapping with $i$ of $\left.\mathrm{PPh}_{2}\right), 132.1\left(\mathrm{~d},{ }^{4} \mathrm{JPC}_{\mathrm{PC}}=2.9 \mathrm{~Hz}, p\right.$ of $\left.\mathrm{PPh}_{2}\right), 131.7\left(\mathrm{~d},{ }^{4} \mathrm{JPC}_{\mathrm{PC}}=2.6 \mathrm{~Hz}, p\right.$ of $\left.\mathrm{PPh}_{2}\right), 131.5\left(\mathrm{~d},{ }^{4} \mathrm{~J}_{\mathrm{PC}}=2.6 \mathrm{~Hz}, p\right.$ of $\left.\mathrm{PPh}_{2}\right), 130.5\left(\mathrm{~d},{ }^{1} J_{\mathrm{CP}}=85.6\right.$ $\mathrm{Hz}, i$ of $\left.\mathrm{PPh}_{2}\right), 129.6\left(\mathrm{~d},{ }^{1} \mathrm{~J}_{\mathrm{CP}}=86.0 \mathrm{~Hz}, i\right.$ of $\left.\mathrm{PPh}_{2}\right), 129.0-128.7(\mathrm{~m}$, overlapping $\mathrm{CH}-\mathrm{Ar}$ ), 128.7-128.4 (m, overlapping $\mathrm{CH}-\mathrm{Ar}), 127.9$ (m, C3 of PAr), 127.5 (d, ${ }^{2} \mathrm{JP}_{\mathrm{CP}}=12.7 \mathrm{~Hz}, \mathrm{C5}$ of PAr), 109.0 (d, ${ }^{1} \mathrm{JP}_{\mathrm{CP}}$ $=88.0 \mathrm{~Hz}, \mathrm{C} 6$ of PAr), $108.2\left(\mathrm{~d},{ }^{1} \mathrm{~J}_{\mathrm{CP}}=108.1 \mathrm{~Hz}, \mathrm{C} 6\right.$ of PAr), $52.5-$ $52.2\left(\mathrm{~m}\right.$, two overlapping $\left.\mathrm{CH}_{2} \mathrm{~N}\right), 51.3\left(\mathrm{~s}, \mathrm{NMe}_{2}\right), 49.0\left(\mathrm{~s}, \mathrm{NMe}_{2}\right)$, $36.2\left(\mathrm{~d},{ }^{4} \mathrm{~J}_{\mathrm{PC}}=1.8 \mathrm{~Hz}, \mathrm{C}\right.$ of $\left.{ }^{t} \mathrm{Bu}^{2}\right), 35.9\left(\mathrm{~d},{ }^{4} J_{\mathrm{PC}}=1.8 \mathrm{~Hz}, \mathrm{C}\right.$ of $\left.{ }^{t} \mathrm{Bu}^{2}\right)$, 34.5 (m, two overlapping $C$ of $\left.{ }^{t} \mathrm{Bu}^{4}\right), 31.8\left(\mathrm{~s}, \mathrm{CH}_{3}\right.$ of $\left.{ }^{t} \mathrm{Bu}^{4}\right), 31.6(\mathrm{~s}$, $\mathrm{CH}_{3}$ of $\left.{ }^{t} \mathrm{Bu}^{4}\right), 30.5\left(\mathrm{~s}, \mathrm{CH}_{3}\right.$ of $\left.{ }^{t} \mathrm{Bu}^{2}\right), 30.3\left(\mathrm{~s}, \mathrm{CH}_{3}\right.$ of $\left.{ }^{t} \mathrm{Bu}^{2}\right)$. Elemental Analysis: calculated for $\mathrm{C}_{58} \mathrm{H}_{76} \mathrm{~N}_{4} \mathrm{O}_{2} \mathrm{P}_{2} \mathrm{Ti}\left(\mathrm{C}_{5} \mathrm{H}_{12}\right)_{0.5}$ : C, 72.15; $\mathrm{H}$, 8.21; N, 5.56. Found: $\mathrm{C}, 71.55 ; \mathrm{H}, 7.86 ; \mathrm{N}, 5.56$. Calculated for $\mathrm{C}_{58} \mathrm{H}_{76} \mathrm{~N}_{4} \mathrm{O}_{2} \mathrm{P}_{2} \mathrm{Ti}: \mathrm{C}, 71.74 ; \mathrm{H}, 7.89 ; \mathrm{N}, 5.77$. The sample was sent for analysis in a sealed ampule under partial vacuum, therefore it is likely that some pentane desorbed between sample preparation and analysis.

\section{Synthesis of complex $7 \mathrm{~b}$}

Proligand $\mathbf{1} \mathbf{b H}_{\mathbf{2}}$ (830 $\mathrm{mg}, 0.938 \mathrm{mmol}$ ) was suspended in pentane and $\mathrm{Ti}\left(\mathrm{NMe}_{2}\right)_{4}(210 \mathrm{mg}, 0.938 \mathrm{mmol})$ was added dropwise. The mixture was stirred for $10 \mathrm{~min}$, affording a redorange solution. After removal of the volatiles, the residue was taken up in pentane, filtered over diatomaceous earth and evaporated to dryness. Complex 7b (650 mg, $68 \%$ ) was obtained as a crusty orange-red solid containing $66 \mathrm{~mol} \%$ of pentane. ${ }^{31} \mathbf{P}\left\{{ }^{1} \mathrm{H}\right\}$ NMR $\left(202 \mathrm{MHz}, \mathrm{C}_{6} \mathrm{D}_{6}, 300 \mathrm{~K}\right): \delta=27.0\left(\mathrm{v}_{1 / 2} \approx 3\right.$ $\mathrm{Hz}), 17.9\left(\mathrm{v}_{1 / 2} \approx 3 \mathrm{~Hz}\right) .{ }^{1} \mathrm{H}$ NMR (500 MHz, $\left.\mathrm{C}_{6} \mathrm{D}_{6}, \mathbf{3 0 0} \mathrm{K}\right): \delta=8.28$ $\left(\mathrm{m}, 2 \mathrm{H}, \mathrm{o}\right.$ of $\left.\mathrm{PPh}_{2}\right), 7.95\left(\mathrm{~m}, 2 \mathrm{H}, \mathrm{o}\right.$ of $\left.\mathrm{PPh}_{2}\right), 7.72\left(\mathrm{~d},{ }^{3} \mathrm{~J}_{\mathrm{PH}}=2.4 \mathrm{~Hz}\right.$, $1 \mathrm{H}, \mathrm{H} 3$ of PAr overlapping with $\mathrm{o}$ of PAr), $7.68\left(\mathrm{~m}, 2 \mathrm{H}, \mathrm{o}\right.$ of $\mathrm{PPh}_{2}$ overlapping with $\mathrm{H} 3$ of $\mathrm{PAr}), 7.62\left(\mathrm{~d},{ }^{3} \mathrm{JHH}_{\mathrm{PH}}=2.6 \mathrm{~Hz}, 1 \mathrm{H}, \mathrm{H} 3\right.$ of $\mathrm{PAr}$ ), $7.28\left(\mathrm{~m}, 2 \mathrm{H}, m\right.$ of $\left.\mathrm{PPh}_{2}\right), 7.19\left(\mathrm{~m}, 1 \mathrm{H}, p\right.$ of $\left.\mathrm{PPh}_{2}\right), 7.13(\mathrm{~m}, 2 \mathrm{H}, o$ of $\mathrm{PPh}_{2}$ overlapping with solvent signal), $7.06\left(\mathrm{~m}, 1 \mathrm{H}, p\right.$ of $\left.\mathrm{PPh}_{2}\right)$, $7.02\left(\mathrm{~m}, 1 \mathrm{H}, p\right.$ of $\left.\mathrm{PPh}_{2}\right), 6.97-6.90\left(\mathrm{~m}, 4 \mathrm{H}\right.$, two $m$ of $\mathrm{PPh}_{2}$ overlapping with $p$ of $\left.\mathrm{PPh}_{2}\right), 6.89\left(\mathrm{~m}, 1 \mathrm{H}, p\right.$ of $\mathrm{PPh}_{2}$ overlapping with $m$ of $\left.\mathrm{PPh}_{2}\right), 6.82\left(\mathrm{dd},{ }^{3} \mathrm{JHH}_{\mathrm{PH}}=16.5 \mathrm{~Hz},{ }^{4} J_{\mathrm{HH}}=2.4 \mathrm{~Hz}, 1 \mathrm{H}, \mathrm{H} 5\right.$ of PAr), $6.75\left(\mathrm{dd},{ }^{3} J_{\mathrm{PH}}=14.7 \mathrm{~Hz},{ }^{4} J_{\mathrm{HH}}=2.4 \mathrm{~Hz}, 1 \mathrm{H}, \mathrm{H} 5\right.$ of $\mathrm{PAr}$ overlapping with $m$ of $\left.\mathrm{PPh}_{2}\right), 6.71\left(\mathrm{~m}, 2 \mathrm{H}, m\right.$ of $\left.\mathrm{PPh}_{2}\right), 6.46(\mathrm{~m}$, $1 \mathrm{H}, H 2$ of NAr), 6.41 (m, 1H, H3 of NAr), $6.26(\mathrm{~m}, 1 \mathrm{H}, H 3$ of NAr), $6.19(\mathrm{~m}, 1 \mathrm{H}, \mathrm{H} 2$ of $\mathrm{NAr}), 3.44\left(\mathrm{~s}, 6 \mathrm{H}, \mathrm{NMe}_{2}\right), 2.91\left(\mathrm{~s}, 6 \mathrm{H}, \mathrm{NMe}_{2}\right)$, $1.76\left(\mathrm{~s}, 9 \mathrm{H}, \mathrm{CH}_{3}\right.$ of $\left.{ }^{t} \mathrm{Bu}^{2}\right), 1.34\left(\mathrm{~s}, 9 \mathrm{H}, \mathrm{CH}_{3}\right.$ of $\left.{ }^{t} \mathrm{Bu}^{2}\right), 1.24\left(\mathrm{~s}, 9 \mathrm{H}, \mathrm{CH}_{3}\right.$ of $\left.{ }^{t} \mathrm{Bu}^{4}\right), 1.17\left(\mathrm{~s}, 9 \mathrm{H}, \mathrm{CH}_{3}\right.$ of $\left.{ }^{t} \mathrm{Bu}^{4}\right) .{ }^{13} \mathrm{C}\left\{{ }^{1} \mathrm{H}\right\}$ NMR (126 MHz, $\mathrm{C}_{6} \mathrm{D}_{6}$, $300 \mathrm{~K}): \delta=169.3\left(\mathrm{~d},{ }^{2} J_{\mathrm{PC}}=3.3 \mathrm{~Hz}, \mathrm{C} 1\right.$ of $\mathrm{PAr}$ ), 167.1 (d, ${ }^{2} J_{\mathrm{PC}}=1.3$ $\mathrm{Hz}, \mathrm{C} 1$ of PAr), 147.4 (dd, ${ }^{3} \mathrm{JC}_{\mathrm{PC}}=10.9 \mathrm{~Hz},{ }^{2} \mathrm{JPC}_{\mathrm{PC}}=2.8 \mathrm{~Hz}, \mathrm{C} 1$ of $\mathrm{NAr}$ ), $144.1\left(\mathrm{dd},{ }^{3} J_{\mathrm{PC}}=19.7 \mathrm{~Hz},{ }^{2} \mathrm{JPC}_{\mathrm{PC}}=2.9 \mathrm{~Hz}, \mathrm{C} 1\right.$ of NAr), $140.7\left(\mathrm{~d},{ }^{3} J_{\mathrm{CP}}\right.$ = 7.7 Hz, C2 of PAr), 139.6 (d, ${ }^{3} J_{\mathrm{CP}}=8.2 \mathrm{~Hz}, C 2$ of PAr), 137.1 (d, ${ }^{3} J_{C P}=15.5 \mathrm{~Hz}, C 4$ of PAr), $134.9\left(\mathrm{~d},{ }^{2} J_{\mathrm{CP}}=8.9 \mathrm{~Hz}\right.$, o of $\left.P P h_{2}\right), 134.3$ $\left(d,{ }^{3} J_{\mathrm{CP}}=15.7 \mathrm{~Hz}, \mathrm{C} 4\right.$ of PAr overlapping with $i$ of $\left.\mathrm{PPh}_{2}\right), 134.0(\mathrm{~d}$, ${ }^{1} J_{\mathrm{PC}}=89.4 \mathrm{~Hz}, i$ of $\mathrm{PPh}_{2}$ overlapping with $C 4$ of PAr and two $o$ of $\left.\mathrm{PPh}_{2}\right), 134.0\left(\mathrm{~d},{ }^{2} \mathrm{~J}_{\mathrm{CP}}=9.9 \mathrm{~Hz}\right.$, o of $\mathrm{PPh}_{2}$ overlapping with $i$ of $\left.\mathrm{PPh}_{2}\right), 133.7\left(\mathrm{~d},{ }^{2} \mathrm{~J}_{\mathrm{CP}}=9.2 \mathrm{~Hz}\right.$, o of $\mathrm{PPh}_{2}$ overlapping with $i$ of $\left.\mathrm{PPh}_{2}\right), 132.8\left(\mathrm{~d},{ }^{1} j_{\mathrm{PC}}=84.8 \mathrm{~Hz}, i\right.$ of $\mathrm{PPh}_{2}$ overlapping with $o$ of $\left.\mathrm{PPh}_{2}\right), 132.6\left(\mathrm{~d},{ }^{2} J_{\mathrm{CP}}=10.9 \mathrm{~Hz}\right.$, o of $\mathrm{PPh}_{2}$ overlapping with $i$ of $\left.\mathrm{PPh}_{2}\right), 131.8\left(\mathrm{~d},{ }^{4} J_{\mathrm{PC}}=2.8 \mathrm{~Hz}, p\right.$ of $\mathrm{PPh}_{2}$ overlapping with $i$ of $\left.\mathrm{PPh}_{2}\right), 131.7\left(\mathrm{~d},{ }^{1} \mathrm{JC}_{\mathrm{PC}}=113.8 \mathrm{~Hz}\right.$, $i$ of $\mathrm{PPh}_{2}$ overlapping with four $p$ of $\left.\mathrm{PPh}_{2}\right), 131.6\left(\mathrm{~d},{ }^{4} \mathrm{~J}_{\mathrm{PC}}=2.6 \mathrm{~Hz}, p\right.$ of $\mathrm{PPh}_{2}$ overlapping with $i$ of $\left.\mathrm{PPh}_{2}\right), 131.5\left(\mathrm{~m}\right.$, two $p$ of $\mathrm{PPh}_{2}$ overlapping with $i$ of $\left.\mathrm{PPh}_{2}\right), 130.1$ $\left(d,{ }^{1} J_{\mathrm{PC}}=85.5 \mathrm{~Hz}\right.$, $i$ of $\mathrm{PPh}_{2}$ ), 129.4 (d, ${ }^{2} J_{\mathrm{CP}}=13.0 \mathrm{~Hz}, \mathrm{C5}$ of PAr), $128.8\left(\mathrm{~d},{ }^{3} \mathrm{JC}_{\mathrm{PC}}=7.7 \mathrm{~Hz}, m\right.$ of $\mathrm{PPh}_{2}$ overlapping with $m$ of $\mathrm{PPh}_{2}$ and C3 of PAr), 128.7 (d, ${ }^{3} \mathrm{JPC}_{\mathrm{PC}}=5.8 \mathrm{~Hz}, m$ of $\mathrm{PPh}_{2}$ overlapping with $m$ of $\mathrm{PPh}_{2}$ and $\mathrm{C} 3$ of $\left.\mathrm{PAr}\right), 128.7\left(\mathrm{~d},{ }^{4} J_{\mathrm{PC}}=2.5 \mathrm{~Hz}, \mathrm{C3}\right.$ of $\mathrm{PAr}$ overlapping with two $m$ of $\left.\mathrm{PPh}_{2}\right), 128.6\left(\mathrm{~d},{ }^{4} \mathrm{JPC}=1.8 \mathrm{~Hz}, \mathrm{C} 3\right.$ of $\mathrm{PAr}), 128.4\left(\mathrm{~d},{ }^{3} \mathrm{JPC}_{\mathrm{PC}}=11.9 \mathrm{~Hz}, m\right.$ of $\left.\mathrm{PPh}_{2}\right), 128.1\left(\mathrm{~d},{ }^{3} \mathrm{~J}_{\mathrm{PC}}=11.2 \mathrm{~Hz}\right.$, $m$ of $\left.\mathrm{PPh}_{2}\right), 127.7\left(\mathrm{~d},{ }^{2} \mathrm{~J}_{\mathrm{CP}}=14.2 \mathrm{~Hz}, \mathrm{C} 5\right.$ of PAr), $124.6(\mathrm{~m}, \mathrm{C2}$ of $\mathrm{NAr}), 120.8\left(\mathrm{~d},{ }^{4} J_{\mathrm{PC}}=1.4 \mathrm{~Hz}, \mathrm{C} 3\right.$ of NAr), $118.9\left(\mathrm{~d},{ }^{3} \mathrm{JPC}_{\mathrm{PC}}=9.1 \mathrm{~Hz}\right.$, $C 2$ of NAr), $117.5\left(\mathrm{~d},{ }^{4} J_{\mathrm{PC}}=1.5 \mathrm{~Hz}, \mathrm{C} 3\right.$ of NAr), $113.4\left(\mathrm{~d},{ }^{1} J_{\mathrm{CP}}=\right.$ 127.2 Hz, C6 of PAr), 107.9 (d, ${ }^{1} J_{\mathrm{CP}}=108.2 \mathrm{~Hz}, \mathrm{C} 6$ of PAr), 51.5 (bs, $\left.\mathrm{NMe}_{2}\right), 49.1\left(\mathrm{~s}, \mathrm{NMe}_{2}\right), 36.1\left(\mathrm{~d},{ }^{4} \mathrm{~J}_{\mathrm{PC}}=1.7 \mathrm{~Hz}, \mathrm{C}\right.$ of $\left.{ }^{\mathrm{t}} \mathrm{Bu}^{2}\right), 35.6$ $\left(\mathrm{d},{ }^{4} J_{\mathrm{PC}}=1.8 \mathrm{~Hz}, \mathrm{C}\right.$ of $\left.{ }^{t} \mathrm{Bu}^{2}\right), 34.3\left(\mathrm{~d},{ }^{4} J_{\mathrm{PC}}=0.9 \mathrm{~Hz}, \mathrm{C}\right.$ of $\left.{ }^{t} \mathrm{Bu}^{4}\right), 34.0$ $\left(\mathrm{d},{ }^{4} \mathrm{~J}_{\mathrm{PC}}=0.7 \mathrm{~Hz}, \mathrm{C}\right.$ of $\left.{ }^{t} \mathrm{Bu}^{4}\right), 31.8\left(\mathrm{~s}, \mathrm{CH}_{3}\right.$ of $\left.{ }^{t} \mathrm{Bu}^{4}\right), 31.7\left(\mathrm{~s}, \mathrm{CH}_{3}\right.$ of $\left.{ }^{t} \mathrm{Bu}^{4}\right), 30.8\left(\mathrm{~s}, \mathrm{CH}_{3}\right.$ of $\left.{ }^{t} \mathrm{Bu}^{2}\right), 30.5\left(\mathrm{~s}, \mathrm{CH}_{3}\right.$ of $\left.{ }^{t} \mathrm{Bu}^{2}\right)$. Elemental Analysis: calculated for $\mathrm{C}_{62} \mathrm{H}_{76} \mathrm{~N}_{4} \mathrm{O}_{2} \mathrm{P}_{2} \mathrm{Ti}\left(\mathrm{C}_{5} \mathrm{H}_{12}\right)_{0.66}: \mathrm{C}, 73.52 ; \mathrm{H}$, 7.93; N, 5.25. Found: C, 72.59; H, 7.70, 5.38.

\section{Synthesis of complex 7c}

To a solution of $1 \mathbf{c H}_{\mathbf{2}}(220 \mathrm{mg}, 0.26 \mathrm{mmol})$ in $2 \mathrm{ml}$ pentane was added $\mathrm{Ti}\left(\mathrm{NMe}_{2}\right)_{4}(58 \mathrm{mg}, 0.26 \mathrm{mmol})$ under argon. After one night stirring at RT the orange precipitate was filtered and washed with pentane $(2 * 2 \mathrm{ml})$ to give of $7 \mathrm{c}$ as an orange solid (180 mg, 72\% yield). ${ }^{31} \mathrm{P}\left\{{ }^{1} \mathrm{H}\right\}$ NMR (243MHz, $\left.\mathrm{C}_{6} \mathrm{D}_{6}, 300 \mathrm{~K}\right): \delta=$ $34.4\left(v_{1 / 2}=3.9 \mathrm{~Hz}\right), 30,3\left(v_{1 / 2}=5.5 \mathrm{~Hz}\right) .{ }^{1} \mathrm{H}$ NMR $\left(600.2 \mathrm{MHz}, \mathrm{C}_{6} \mathrm{D}_{6}\right.$, $300 \mathrm{~K}): \delta=8.16\left(\mathrm{dd},{ }^{3} \mathrm{PH}_{\mathrm{PH}}=12.53 \mathrm{~Hz},{ }^{3} J_{\mathrm{HH}}=7.67 \mathrm{~Hz}, 2 \mathrm{H}, o\right.$ of $\mathrm{PPh}_{2}$ ), 7.82-7.77 $\left(\mathrm{m}, 2 \mathrm{H}, \mathrm{O}\right.$ of $\left.\mathrm{PPh}_{2}\right), 7.76\left(\mathrm{~d},{ }^{4} \mathrm{~J}_{\mathrm{HH}}=2.31 \mathrm{~Hz}, 1 \mathrm{H}, \mathrm{H3}\right.$ of PAr), $7.74\left(\mathrm{~d},{ }^{4} J_{\mathrm{HH}}=2.31 \mathrm{~Hz}, 1 \mathrm{H}, \mathrm{H} 3\right.$ of PAr), $7.59\left(\mathrm{dd},{ }^{3} \mathrm{PH}_{\mathrm{PH}}=8.88\right.$ $\mathrm{Hz},{ }^{3} J_{\mathrm{HH}}=7.34 \mathrm{~Hz}, 2 \mathrm{H}, o$ of $\left.\mathrm{PPh}_{2}\right), 7.49\left(\mathrm{dd},{ }^{3} \mathrm{JPH}_{\mathrm{PH}}=8.94 \mathrm{~Hz},{ }^{3} J_{\mathrm{HH}}=\right.$ $7.32 \mathrm{~Hz}, 2 \mathrm{H}, O$ of $\left.\mathrm{PPh}_{2}\right), 7.22\left(\mathrm{t}, 3_{\mathrm{HH}}=7.22 \mathrm{~Hz}, 2 \mathrm{H}, m\right.$ of $\left.\mathrm{PPh}_{2}\right)$, 7.14-7.07 $\left(\mathrm{m}, 4 \mathrm{H}, 2 \mathrm{~m}\right.$ and $2 p$ of $\left.\mathrm{PPh}_{2}\right), 7.06-6.95(\mathrm{~m}, 6 \mathrm{H}, 2 \mathrm{~m}$ and $2 p$ of $\mathrm{PPh}_{2}$ and $2 \mathrm{H} 5$ of PAr), $6.91\left(\mathrm{t},{ }^{3} \mathrm{H}_{\mathrm{HH}}=7.60 \mathrm{~Hz}, 2 \mathrm{H}, m\right.$ of $\left.\mathrm{PPh}_{2}\right)$, 4.18-4.04 (m, $\left.1 \mathrm{H}, \mathrm{NCH}_{2}\right), 3.63-3.51\left(\mathrm{~m}, 1 \mathrm{H}, \mathrm{NCH}_{2}\right), 3.34(\mathrm{~s}, 6 \mathrm{H}$, $\left.\mathrm{NMe}_{2}\right), 3.06-2.90\left(\mathrm{~m}, 1 \mathrm{H}, \mathrm{NCH}_{2}\right), 2.91\left(\mathrm{~s}, 6 \mathrm{H}, \mathrm{NMe}_{2}\right), 2.77-2.67$ $\left(\mathrm{m}, 1 \mathrm{H}, \mathrm{NCH}_{2}\right), 1.81\left(\mathrm{~s}, 9 \mathrm{H},{ }^{t} \mathrm{Bu}^{2}\right), 1.63\left(\mathrm{~s}, 9 \mathrm{H},{ }^{t} \mathrm{Bu}^{2}\right), 1.28-1.21(\mathrm{~m}$, $\left.2 \mathrm{H}, \mathrm{NCH}_{2} \mathrm{CH}_{2}\right), 1.23\left(\mathrm{~s}, 9 \mathrm{H},{ }^{t} \mathrm{Bu}^{4}\right), 1.20\left(\mathrm{~s}, 9 \mathrm{H},{ }^{t} \mathrm{Bu}^{4}\right) .{ }^{13} \mathrm{C} \mathrm{NMR}$ 
(150.9 MHz, $\mathrm{C}_{6} \mathrm{D}_{6}, 300 \mathrm{~K}$ ): $\delta=169.7$ (s, $C 1$ of PAr), 166.4 (s, $C 1$ of PAr), 140.4 (d, ${ }^{3} J_{C P}=7.5 \mathrm{~Hz}, C 2$ of PAr), $140.0\left(\mathrm{~d},{ }^{3} J_{\mathrm{CP}}=8.2 \mathrm{~Hz}, \mathrm{C2}\right.$ of PAr), $136.0\left(d,{ }^{3} J_{C P}=15.1 \mathrm{~Hz}, C 4\right.$ of PAr), $135.5\left(d,{ }^{1} J_{C P}=91.8 \mathrm{~Hz}\right.$, $C i$ of $\left.\mathrm{PPh}_{2}\right), 134.4\left(\mathrm{~d},{ }^{2} \mathrm{~J}_{\mathrm{CP}}=3.2 \mathrm{~Hz}\right.$, o of $\left.\mathrm{PPh}_{2}\right), 134.3\left(\mathrm{~d},{ }^{2} J_{\mathrm{CP}}=2.9\right.$ $\mathrm{Hz}, o$ of $\left.P P h_{2}\right), 133.4\left(d,{ }^{3} J_{C P}=13.6 \mathrm{~Hz}, C 4\right.$ of PAr), $133.3\left(d,{ }^{1} J_{C P}=\right.$ 102.1 Hz, Ci of $\mathrm{PPh}_{2}$ ), $133.0\left(\mathrm{~d},{ }^{2} J_{\mathrm{CP}}=9.7 \mathrm{~Hz}, o\right.$ of $\left.\mathrm{PPh}_{2}\right), 132.0(\mathrm{~d}$, ${ }^{2} J_{C P}=10.2 \mathrm{~Hz}, o$ of $\left.P P h_{2}\right), 131.2\left(d,{ }^{1} J_{C P}=89.4 \mathrm{~Hz}, C\right.$ of $\left.P P h_{2}\right), 131.1$ $\left(p\right.$ of $\left.\mathrm{PPh}_{2}\right) 130.9$ ( $p$ of $\left.\mathrm{PPh}_{2}\right), 130.7\left(p\right.$ of $\left.\mathrm{PPh}_{2}\right), 130.6\left(\mathrm{~d},{ }^{1} J_{\mathrm{CP}}=\right.$ $87.2 \mathrm{~Hz}, C$ of $\left.P P h_{2}\right), 130.5$ ( $p$ of $P P h_{2}$ ), 128.9 (d, ${ }^{2} J_{C P}=10.9 \mathrm{~Hz}, C 5$ of PAr), 128.6-126.9 (overlapping $2 C 3$ and $C 5$ of PAr with $m$ of $\left.\mathrm{PPh}_{2}\right), 111.4\left(\mathrm{~d},{ }^{1} J_{\mathrm{CP}}=118.4 \mathrm{~Hz}, \mathrm{Ci}\right.$ of $\left.\mathrm{PAr}\right), 115.8\left(\mathrm{~d},{ }^{1} J_{\mathrm{CP}}=108.5\right.$ $\mathrm{Hz}, \mathrm{Ci}$ of PAr), 51.1 (s, NMe $), 50.1$ (s, NMe $\mathrm{NM}_{2}, 46.5$ (d, ${ }^{2} J_{\mathrm{CP}}=3.3$ $\mathrm{Hz}, \mathrm{NCH}_{2}$ ), ), $44.6\left(\mathrm{~d},{ }^{2} \mathrm{~J}_{\mathrm{CP}}=4.4 \mathrm{~Hz}, \mathrm{NCH}_{2}\right.$ ), 35.8 (s, C of $t \mathrm{Bu}^{2}$ ), 35.7 (s, $\mathrm{C}$ of $\left.t \mathrm{Bu}^{2}\right), 33.9\left(\mathrm{~s}, \mathrm{C}\right.$ of $\left.t \mathrm{Bu}^{4}\right), 33.8\left(\mathrm{~s}, \mathrm{C}\right.$ of $\left.t \mathrm{Bu}^{4}\right), 33.2\left(\mathrm{~s}, \mathrm{NCH}_{2^{-}}\right.$ $\mathrm{CH}_{2}$ ), 31.5 (s, $\left.\mathrm{CH}_{3}, t \mathrm{Bu}\right), 31.4$ (s, $\left.\mathrm{CH}_{3}, t \mathrm{Bu}\right), 30.6$ (s, $\left.\mathrm{CH}_{3}, t \mathrm{Bu}\right), 30.4$ (s, $\mathrm{CH}_{3}, t \mathrm{Bu}$ ). HRMS (ESI-pos): calculated for $\mathrm{C}_{56} \mathrm{H}_{69} \mathrm{~N}_{2} \mathrm{O}_{3} \mathrm{P}_{2} \mathrm{Ti}^{+}[\mathrm{M}-$ 2( $\left.\left.\mathrm{NMe}_{2}\right)+\mathrm{OMe}\right]^{+}:$927.42574. Found: 927.42835 (+2.8 ppm).

\section{Typical procedure for rac-lactide polymerization}

In a glovebox, the catalyst $\left(2,5 \cdot 10^{-6} \mathrm{~mol}, 1\right.$ equiv) and rac-lactide (100 equiv) were charged in a vial equipped with a TeflonTMtight screw cap and toluene (for a $1 \mathrm{M}$ in rac-lactide) was added. Addition of ${ }^{i} \mathrm{PrOH}$ ( 1 equiv) is also done for selected runs. The resulting mixture was heated at the appropriate temperature under vigorous stirring for the desired time. The vial was then removed from the glovebox and the reaction mixture was quenched with pentane provoking the precipitation of the polymer, which was washed several times with pentane, dried in vacuum until constant weight. The sample was subsequently analyzed by ${ }^{1} \mathrm{H}$ NMR, GPC and by MALDI-TOF spectrometry.

\section{Conflicts of interest}

There are no conflicts to declare.

\section{Acknowledgements}

Support was provided by the Ministère de l'Enseignement Supérieur et de la Recherche, and the Centre National de la Recherche Scientifique (CNRS). This work is part of the project CHIMIE DURABLE, ENVIRONNEMENT ET AGROALIMENTAIRE, supported by the Universite de Bourgogne, Conseil Régional de Bourgogne through the plan d'actions régional pour I'innovation (PARI) and the European Union through the PO FEDER-FSE Bourgogne 2014/2020 programs. We thank also Ecole Polytechnique and Université de Strasbourg for financial support.

\section{Notes and references}

$\S$ Crystallographic $\mathrm{C} 2$ axis for $\mathbf{1} \mathbf{a H}_{\mathbf{2}}$ while approximate $\mathrm{C} 2$ axis for $1 \mathrm{cH}_{2}$

$\S \S$ Expanded uncertainties at the 95\% confidence interval are estimated from the residual variance of the fit.
1 Synthesis and Production of Poly(lactic Acid), William Andrew Publishing, Oxford, 2013.

2 V. Nagarajan, A. K. Mohanty and M. Misra, ACS Sustainable Chemistry \& Engineering, 2016, 4, 2899-2916.

3 For reviews, see: (a) B. J. O'Keefe, M. A. Hillmyer and W. B. Tolman, J. Chem. Soc., Dalton Trans., 2001, 2215-2224; (b) O. Dechy-Cabaret, B. Martin-Vaca and D. Bourissou, Chem. Rev., 2004, 104, 6147-6176; (c) C. M. Thomas, Chem. Soc. Rev., 2010, 39, 165-173; (d) M. J. Stanford, A. P. Dove, Chem. Soc. Rev., 2010, 39, 486-494; (e) J.-C. Buffet, J. Okuda, Polym. Chem., 2011, 2, 2758-2763; (f) S. Dagorne, M. Normand, E. Kirillov, J.-F. Carpentier, Coord. Chem. Rev., 2013, 257, 18691886; (g) S. M. Guillaume, E. Kirillov, Y. Sarazin, J.-F. Carpentier, Chem. Eur. J., 2015, 21, 7988-8003.

4 For reviews, see: (a) A. Sauer, A. Kapelski, C. Fliedel, S. Dagorne, M. Kol, J. Okuda, Dalton Trans., 2013, 42, $9007-$ 9023; (b) E. Le Roux, Coord. Chem. Rev., 2016, 306, Part 1, 6585.

5 (a) C. K. A. Gregson, I. J. Blackmore, V. C. Gibson, N. J. Long, E. L. Marshall, A. J. P. White, Dalton Trans., 2006, 3134-3140; (b) B. Gao, X. Li, R. Duan, X. Pang, New J. Chem., 2015, 39, 24042408.

6 (a) A. J. Chmura, M. G. Davidson, M. D. Jones, M. D. Lunn, M. F. Mahon, A. F. Johnson, P. Khunkamchoo, S. L. Roberts, S. S. F. Wong, Macromolecules, 2006, 39, 7250-7257; (b) E. L. Whitelaw, M. D. Jones, M. F. Mahon, Inorg. Chem., 2010, 49, 7176-7181; (c) E. L. Whitelaw, M. G. Davidson, M. D. Jones, Chem. Commun., 2011, 47, 10004-10006; (d) M. D. Jones, S. L. Hancock, P. McKeown, P. M. Schafer, A. Buchard, L. H. Thomas, M. F. Mahon, J. P. Lowe, Chem. Commun., 2014, 50, 15967-15970; (e) M. D. Jones, L. Brady, P. McKeown, A. Buchard, P. M. Schafer, L. H. Thomas, M. F. Mahon, T. J. Woodman, J. P. Lowe, Chem. Sci., 2015, 6, 5034-5039; (f) S. M. Kirk, G. Kociok-Köhn, M. D. Jones, Organometallics, 2016, 35, 3837-3843; (g) A. Stopper, T. Rosen, V. Venditto, I. Goldberg, M. Kol, Chem. Eur. J., 2017, 23, 11540-11548.

7 (a) T.-P.-A. Cao, S. Labouille, A. Auffrant, Y. Jean, X. F. Le Goff, P. Le Floch, Dalton Trans., 2011, 40, 10029-10037; (b) I. M. Marín, A. Auffrant, Eur. J. Inorg. Chem., 2018, 1634-1644.

8 (a) C. Bakewell, T.-P.-A. Cao, N. Long, X. F. Le Goff, A. Auffrant, C. K. Williams, J. Am. Chem. Soc., 2012, 134, 20577-20580; (b) T.-P.-A. Cao, A. Buchard, X. F. Le Goff, A. Auffrant and C. K. Williams, Inorg. Chem., 2012, 51, 2157-2169; (c) C. Bakewell, T.-P.-A. Cao, X. F. Le Goff, N. J. Long, A. Auffrant, C. K. Williams, Organometallics, 2013, 32, 1475-1483; (d) C. Bakewell, A. J. P. White, N. J. Long, C. K. Williams, Angew. Chem. Int. Ed., 2014, 53, 9226-9230; (e) C. Bakewell, A. J. P. White, N. J. Long, C. K. Williams, Inorg. Chem., 2015, 54, 2204-2212; (f) D. Myers, A. J. P. White, C. M. Forsyth, M. Bown, C. K. Williams, Angew. Chem. Int. Ed., 2017, 56, 5277-5282.

9 M. G. Davidson, A. E. Goeta, J. A. K. Howard, C. W. Lehmann, G. M. McIntyre, R. D. Price, J. Organomet. Chem., 1998, 550, 449-452.

10 T. K. K. Dickie, C. S. MacNeil, P. G. Hayes, Dalton Trans. 2020, 49, 578-582.

11 A. Shafir, D. Fiedler, J. Arnold, J. Chem. Soc., Dalton Trans., 2002, 555-560.

12 A. Stopper, J. Okuda, M. Kol, Macromolecules, 2012, 45, 698704.

13 Similar dinuclear $\mathrm{Zr}$ complexes bridged by salen ligands have been reported, see: M. Mandal, V. Ramkumar, D. Chakraborty, Polym. Chem., 2019, 10, 3444-3460.

14 The formation of a zircona-aziridine metallacycle through $\mathrm{CH}$ activation of a salen ligand by a benzyl group has been previously described, see: P. D. Knight, I. Munslow, P. N. O'Shaughnessy, P. Scott, Chem. Commun., 2004, 894-895.

15 (a) S. Gong, H. Ma, J. Huang, Dalton Trans., 2009, 8237-8247; (b) I. El-Zoghbi, S. Latreche, F. Schaper, Organometallics, 
2010, 29, 1551-1559; (c) I. El-Zoghbi, T. J. J. Whitehorne, F. Schaper, Dalton Trans., 2013, 42, 9376-9387.

16 a) N. Nomura, R. Ishii, Y. Yamamoto, T. Kondo, Chem. Eur. J., 2007, 13, 4433-4451; (b) L. Wang, C. E. Kefalidis, S. Sinbandhit, V. Dorcet, J.-F. Carpentier, L. Maron and Y. Sarazin, Chem. Eur. J., 2013, 19, 13463-13478; (c) H. Wang, Y. Yang and H. Ma, Macromolecules, 2014, 47, 7750-7764.

17 C. Kan, J. Ge and H. Ma, Dalton Trans., 2016, 45, 6682-6695.

18 (a) Y. Sarazin, J.-F. Carpentier, Chem. Rev., 2015, 115, 35643614; (b) M. Hayakawa, M. Mitani, T. Yamada, T. Mukaiyama, Macromol. Chem. Phys., 1997, 198, 1305-1317.

19 (a) J.-C. Buffet and J. Okuda, Chem. Commun., 2011, 47, 47964798; (b) S. L. Hancock, M. F. Mahon and M. D. Jones, Chem. Cent. J., 2013, 7, 135-135; (c) F. Della Monica, E. Luciano, G. Roviello, A. Grassi, S. Milione and C. Capacchione, Macromolecules, 2014, 47, 2830-2841.

20 U. Zucchini, E. Albizzati, U. Giannini, J. Organomet. Chem., 1971, 26, 357-372.

21 G. R. Fulmer, A. J. M. Miller, N. H. Sherden, H. E. Gottlieb, A. Nudelman, B. M. Stoltz, J. E. Bercaw and K. I. Goldberg, Organometallics, 2010, 29, 2176-2179.

22 O. V. Dolomanov, L. J. Bourhis, R. J. Gildea, J. A. K. Howard and H. Puschmann, J. Appl. Crystallogr., 2009, 42, 339-341.

23 G. Sheldrick, Acta Crystallogr. Sect. A, 2015, 71, 3-8.

24 G. Sheldrick, Acta Crystallogr. Sect. C, 2015, 71, 3-8. 